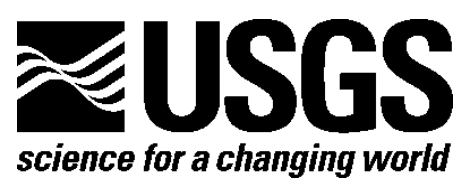

\title{
Deep-Sea Turbidites as Guides to Holocene Earthquake History at the Cascadia Subduction Zone- Alternative Views for a Seismic-Hazard Workshop
}

Brian F. Atwater and Gary B. Griggs

Open-File Report 2012-1043

U.S. Department of the Interior

U.S. Geological Survey 


\section{U.S. Department of the Interior \\ KEN SALAZAR, Secretary}

\section{U.S. Geological Survey \\ Marcia K. McNutt, Director}

U.S. Geological Survey, Reston, Virginia: 2012

For product and ordering information:

World Wide Web: http://www.usgs.gov/pubprod

Telephone: 1-888-ASK-USGS

For more information on the USGS—-the Federal source for science about the Earth, its natural and living resources, natural hazards, and the environment:

World Wide Web: http://www.usgs.gov

Telephone: 1-888-ASK-USGS

Suggested citation:

Atwater, B.F., and Griggs, G.B., 2012, Deep-sea turbidites as guides to Holocene earthquake history at the Cascadia Subduction Zone-Alternative views for a seismic-hazard workshop: U.S. Geological Survey Open-File Report 2012-1043, 58 p., available at $h$ ttp://pubs.usgs.gov/of/2012/1043/.

Any use of trade, product, or firm names is for descriptive purposes only and does not imply endorsement by the U.S. Government.

Although this report is in the public domain, permission must be secured from the individual copyright owners to reproduce any copyrighted material contained within this report. 


\section{Contents}

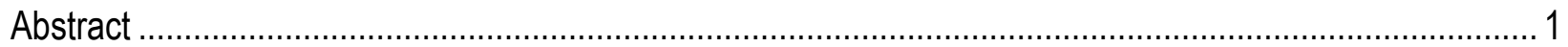

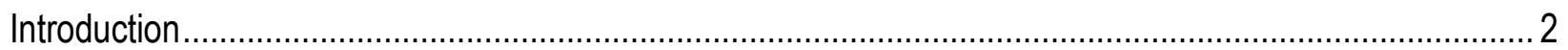

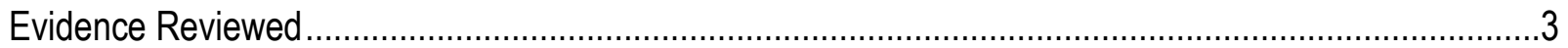

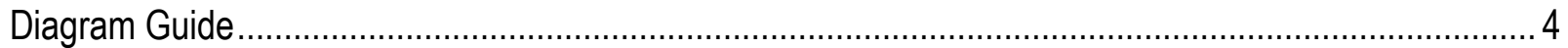

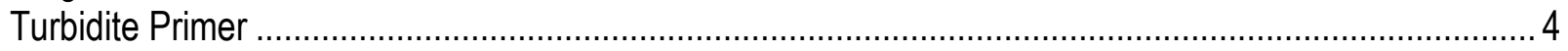

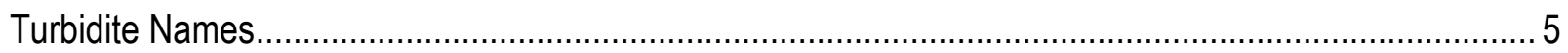

Correlations Deduced from Turbidite Counts................................................................................ 6

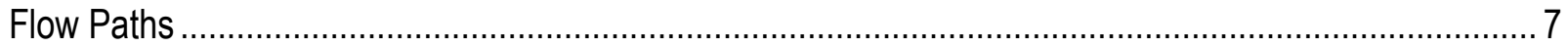

Backflooding of Side Valleys ....................................................................................................

Shortcuts from Quinault Canyon to Lower Juan de Fuca Channel .................................................. 8

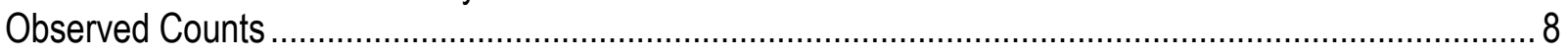

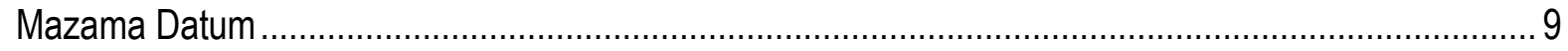

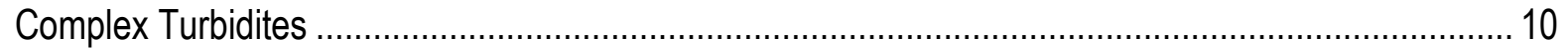

Time Lags in Cascadia Channel............................................................................................ 10

Inequality Between Juan de Fuca and Quinault-Willapa Flows...................................................... 11

Attrition of Juan de Fuca Flows ........................................................................................ 12

Inferred Dominance of Quinault-Willapa Flows ……………….............................................. 12

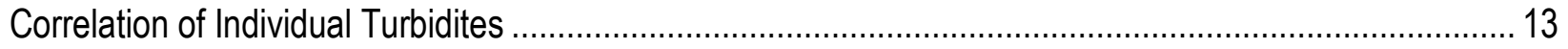

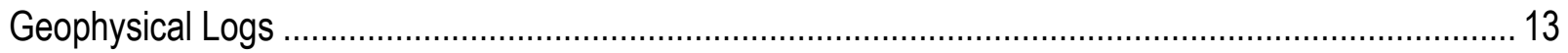

Simplicity and Variability of the Inferred Signatures .................................................................... 14

Sedimentary Shredding of Seismological Signals .................................................................. 14

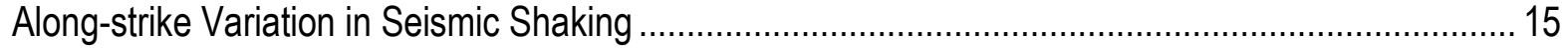

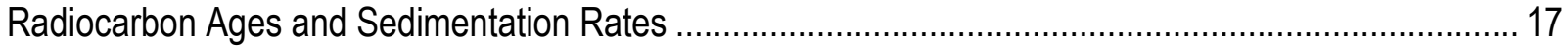

Converting Foraminiferal Ages into Turbidite Ages .................................................................. 17

Further Uncertainty About Rates of Hemipelagic Deposition............................................................. 18

Further Uncertainty About the Thickness of Hemipelagic Deposits Lost to Erosion ........................... 19

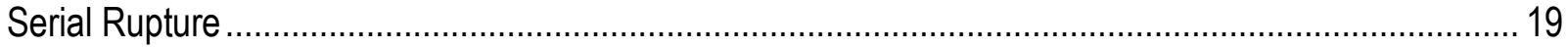

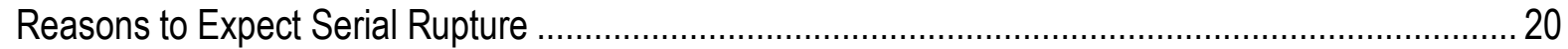

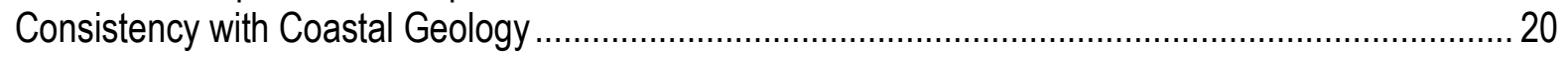

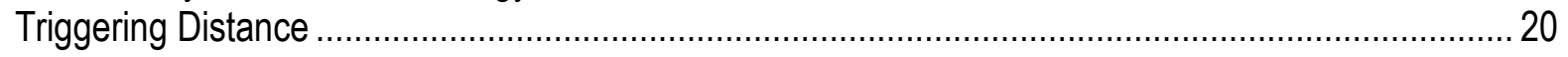

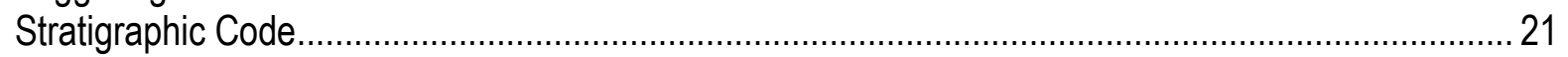

Correlation with Onshore Evidence in Southern Washington and Northernmost Oregon ....................... 21

Onshore Evidence Correlative with Turbidite J2 ………….................................................... 22

Passage of Time Inferred from Burrowed Turbidites and Forested Tidelands.................................... 22

Consistency with Confluence Test, Geophysical Logs, and Radiocarbon Ages.................................. 23

Consistency with Coastal Land-Level Changes .......................................................................... 24

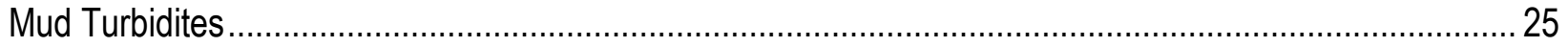

Apparent Absence Offshore Washington ................................................................................... 25

Initiation of Flows Offshore Oregon and Northern California ............................................................. 25

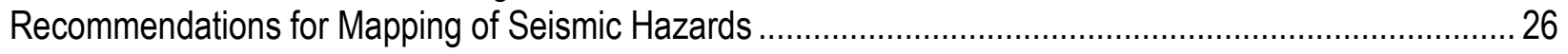

Earthquakes of $M 9$ offshore Southern Washington and Beyond..................................................... 26

Earthquake Recurrence Offshore Southern British Columbia and Northern Washington ....................... 27

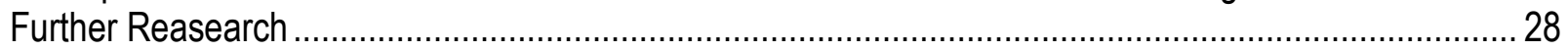

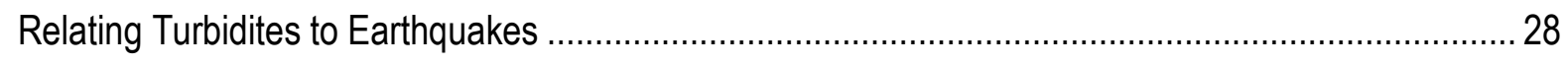




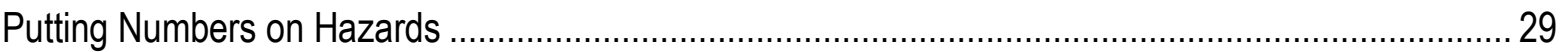

Acknowledgments and Author Responsibilities ........................................................................... 29

Appendix-Generating Mud Turbidites Apart from Great Earthquakes ................................................. 29

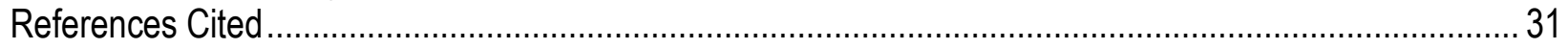

\section{Tables}

1. Examples of deep-sea turbidites that have been correlated with earthquakes outside of Cascadia ..... 44

2. Counts of turbidites that are known or inferred to postdate the eruption of Mount Mazama (Oregon)

$7,800-7,500$ sidereal years ago

\section{Figures}

1. Bathymetric profiles and index map for Cascadia Subduction Zone

2. Locations of submarine canyons and channels, and of cores, in the network of Cascadia Channel..... 50

3. Skeletal views of the confluence test at Cascadia Channel and its tributaries

4. Previously unpublished details about cores collected in the late 1960s from Cascadia Channel and its tributaries

5. Geophysical logs used by Goldfinger and others (in press) in correlating turbidites between Juan de Fuca Channel and lower Cascadia Channel...

6. Steps used recently in adjusting radiocarbon ages to estimate times of deep-sea turbidite deposition along the Cascadia Subduction Zone

7. Uncertainties in adjustments to radiocarbon ages for turbidites in Cascadia Channel and Juan de Fuca Channel.

8. Comparisons of earthquake ages inferred from offshore and onshore evidence..... 


\title{
Deep-Sea Turbidites as Guides to Holocene Earthquake History at the Cascadia Subduction Zone- Alternative Views for a Seismic-Hazard Workshop
}

Brian F. Atwater ${ }^{1}$ and Gary B. Griggs ${ }^{2}$

\begin{abstract}
This report reviews the geological basis for some recent estimates of earthquake hazards in the Cascadia region between southern British Columbia and northern California. The largest earthquakes to which the region is prone are in the range of magnitude 8-9. The source of these great earthquakes is the fault down which the oceanic Juan de Fuca Plate is being subducted or thrust beneath the North American Plate. Geologic evidence for their occurrence includes sedimentary deposits that have been observed in cores from deep-sea channels and fans. Earthquakes can initiate subaqueous slumps or slides that generate turbidity currents and which produce the sedimentary deposits known as turbidites. The hazard estimates reviewed in this report are derived mainly from deep-sea turbidites that have been interpreted as proxy records of great Cascadia earthquakes. The estimates were first published in 2008. Most of the evidence for them is contained in a monograph now in press. We have reviewed a small part of this evidence, chiefly from Cascadia Channel and its tributaries, all of which head offshore the Pacific coast of Washington State.

According to the recent estimates, the Cascadia plate boundary ruptured along its full length in 19 or 20 earthquakes of magnitude 9 in the past 10,000 years; its northern third broke during these giant earthquakes only, and southern segments produced at least 20 additional, lesser earthquakes of Holocene age. The turbidite case for full-length ruptures depends on stratigraphic evidence for simultaneous shaking at the heads of multiple submarine canyons. The simultaneity has been inferred primarily from turbidite counts above a stratigraphic datum, sandy beds likened to strong-motion records, and radiocarbon ages adjusted for turbidity-current erosion.

In alternatives proposed here, this turbidite evidence for simultaneous shaking is less sensitive to earthquake size and frequency than previously thought. Turbidites far below a channel confluence, instead of representing the merged flows from two tributaries, monitor the dominant tributary only. Sandy beds low in the turbidites, instead of matching from channel to channel, permit divergent stratigraphic correlations; and rather than approximating strong-motion seismograms, the sandy beds more likely record processes internal to the generation and
\end{abstract}

\footnotetext{
${ }^{1}$ U.S. Geological Survey.

${ }^{2}$ Earth and Planetary Sciences Department and Institute of Marine Sciences, University of California Santa Cruz, Santa Cruz, Calif.
} 
transformation of subaqueous mass movements. The age adjustments, instead of supporting other evidence that all the northern ruptures were long, are uncertain enough to accord with variation in rupture mode, and this variation improves agreement with onshore paleoseismology. Many of the turbidites counted as evidence for frequent earthquakes on the southern Cascadia plate boundary may instead reflect nearness to steep slopes.

This report is meant to aid in the updating of national maps of seismic hazards in Canada and the United States. It offers three main conclusions for consideration at a U.S. hazard-map workshop slated for March 21-22, 2012:

- If giant earthquakes are the norm for the plate boundary offshore southern Washington, the strongest paleoseismic evidence for this rupture mode is the average earthquake-recurrence interval of about 500 years that is evidenced both offshore in lower Cascadia Channel and onshore at estuaries of southern Washington and northernmost Oregon.

- The plate boundary offshore southern British Columbia and northern Washington may be capable of producing great earthquakes at an average interval as short as 300 years that is evidenced mainly onshore.

- Review of more of the turbidite evidence now in press may clarify implications for the hazard maps. Further work on the deep-sea turbidites could target sedimentary processes and chronological uncertainties that may affect the turbidites' sensitivity to fault-rupture lengths and recurrence rates.

\section{Introduction}

Earthquakes are among the ways of setting off submarine mass movements that can initiate turbidity currents (Piper and Normark, 2009). Turbidity currents are mixtures of sediment and water driven forward by sediment that has pulled interstitial water down slope and which has been kept in suspension by fluid turbulence (Bagnold, 1962; Lowe, 1972; Middleton and Hampton, 1973; Middleton, 1993). Turbidites are the deposits of turbidity currents (Kuenen and Migliorini, 1950; Bouma, 1962).

At the Cascadia Subduction Zone, which extends 1,100 km along the Pacific coast of North America (fig. 1), studies of deep-sea turbidites began with LaVerne Kulm and his students in the late 1960s (Griggs, 2011). The studies showed that Holocene turbidity currents had run hundreds of kilometers down a deep-sea channel at intervals averaging close to 500 yearsinfrequent catastrophes that were at first ascribed to "periodic earthquakes or severe storms" (Griggs and Kulm, 1970b, p. 1382). Later, after geophysical debate on whether great earthquakes can happen at Cascadia (Ando and Balazs, 1979; Savage and others, 1981; Reilinger and Adams, 1982; Heaton and Hartzell, 1987; Rogers, 1988), turbidites helped show that they do occur (Adams, 1990; Thompson, 2011). A later series of studies, described most fully by Goldfinger and others (in press), has strengthened today's consensus that the Cascadia plate boundary produces great earthquakes relentlessly.

This report reviews three further interpretations of deep-sea turbidites at the Cascadia Subduction Zone: (1) the Cascadia plate boundary produced 19 or 20 giant, approximately magnitude $(M) 9$ earthquakes in the past 10,000 years by rupturing along most or all of its length; (2) the northern third of the plate boundary broke during these giant earthquakes only; and (3) the giant earthquakes were interspersed farther south with a similar number of additional plateboundary earthquakes of $M \sim 8$.

These interpretations resulted from more than a decade's research by Chris Goldfinger and many coworkers. They were first reported in advance summaries (Goldfinger and others, 
2008; Goldfinger, 2009; Gutierrez-Pastor and others, 2009; Priest and others, 2010; Goldfinger, 2011). The interpretations quickly became important as guides to tsunami hazards in Oregon (Priest and others, 2010; Witter and others, 2011), as grounds for revising ground-motion estimates throughout the Cascadia region (Frankel, 2011), and as a leading example of turbidite paleoseismology worldwide (other examples, table 1). The interpretations rest on the wealth of new evidence in the report of Goldfinger and others (in press), hereinafter "the monograph."

We review a small but central part of the new evidence in light of core logs from the 1960s, initial paleoseismological interpretations published in 1990, advances in turbidite sedimentology, and onshore evidence for great Cascadia earthquakes. The review was begun for a November 2010 workshop on applying deep-sea turbidite evidence to the U.S. National Seismic Hazard Maps (Frankel, 2011), and it is being released in this preliminary form for a follow-up workshop slated for March 2012.

\section{Evidence Reviewed}

The monograph of Goldfinger and others (in press) presents turbidite evidence from a dozen deep-sea areas that together span most of the length of the Cascadia Subduction Zone (fig. 1). For each of these areas it brings together core photos, core sketches, logs of density and magnetic susceptibility, volcanic-ash content, turbidite ages derived from radiocarbon dating, turbidite ages derived from sedimentation rates, and stratigraphic correlations inferred from these various lines of evidence. The turbidite ages are derived in accompanying spreadsheets that show how the sedimentation rates were estimated and how the radiocarbon ages, which were measured on foraminifera, were adjusted for estimated differences between the ages of the dated carbonate tests and the times of the turbidity currents.

The monograph text explores how the turbidity currents were initiated. The possibilities considered, in addition to great plate-boundary earthquakes, include storm waves, flood discharge, tsunami-induced currents, and lesser earthquakes. Some of the reasons cited for favoring great earthquakes are sedimentological, whereas others hinge on inference that turbidity currents were initiated at the same time in multiple submarine canyons. This part of the monograph expands on the reply of Goldfinger and others (2009) to a comment from Shanmugam (2009) about the triggering of turbidity currents.

The monograph concludes with inferences about the size and frequency of great Cascadia earthquakes. The inferred history spans 10,000 years or more, defines spatial and temporal variation in rupture length, and may include earthquakes smaller than those detectable by means of coastal paleoseismology.

Our review of the monograph focuses topically on stratigraphic correlations that underpin its use of the turbidites as proxy records of earthquakes and as guides to earthquake size and frequency. The correlations depend on three kinds of evidence reviewed below: (1) turbidite counts, (2) geophysical logs, and (3) radiocarbon ages. We also revisit an offshore-onshore correlation and touch on turbidite evidence for a twofold north-south difference in earthquake frequency.

Geographically we focus on Cascadia Channel and its tributaries, all of which head in submarine canyons off the Washington coast (figs. 1-3). No Cascadia plate-boundary rupture can extend the full length of the subduction zone without passing beneath these canyons. Turbidites derived from them provided an initial basis for estimating fault-rupture length at Cascadia - the confluence test of Adams (1990). Our direct experience with Cascadia paleoseismology is mostly limited to these turbidites (Griggs, 1969; Griggs, 2011) and to probably correlative evidence on the Washington coast (Atwater and Hemphill-Haley, 1997, p. 
102-103). Additional studies from the 1970s and 1980s provide context from the Washington continental shelf (Nittrouer and others, 1979; Nittrouer and Sternberg, 1981; Sternberg, 1986; Healy Ridge and Carson, 1987) and slope (Barnard, 1973; Baker, 1976b; Barnard, 1978; Carson and others, 1986) and from an abyssal fan offshore northern Washington (Carson, 1971; Baker, 1976a; Stokke and others, 1977).

\section{Diagram Guide}

Although the monograph is copiously illustrated, further depictions of physiographic setting (figs. 1-4), stratigraphy (figs. 4, 5), and dating (figs. 6-8) aid in reviewing the turbidite evidence it presents. The next few paragraphs introduce several of these diagrams.

Figure 4 shows sedimentological details from turbidite logs on file at Oregon State University. It reproduces schematic grain-size trends that Griggs sketched in the late 1960s when logging cores from Cascadia Channel and its tributaries. The trends reveal complexity not apparent from the generalized logs in Griggs's dissertation and derivative articles (Griggs and others, 1969; Griggs, 1969; Griggs and Kulm, 1970b). Symbolized beside the trends are some of Griggs's sample analyses, which in addition to measurements of particle size included counts of volcanic-ash particles.

Figure 5 complements the monograph's depictions of its geophysical logs of cores from Juan de Fuca and Cascadia Channels. The logs show two main proxies for grain size: wet bulk density (measured by attenuation of gamma rays; gamma density) and magnetic susceptibility. To help see how well they match, turbidite by turbidite, we extracted them from the monograph's figures 19 and 24, cut them into segments that embrace a turbidite and any overlying hemipelagic deposits, and aligned the segments by the correlations inferred in the monograph.

Figures 6-8 examine dating that bears on turbidite correlation between deep-sea channels and on paleoseismological correlation between offshore and onshore. Goldfinger and others (in press) shifted some of the turbidite ages to adjust for differences between the age of material dated and the time of the ensuing turbidity current (figs. $6 B, 8 B, C$ ). Figure 6 shows the steps used in these adjustments; figures $6 E$ and 7 , depict the associated uncertainties; and figure $8 D-F$ applies the results to offshore-onshore correlation.

\section{Turbidite Primer}

A turbidite triggered by an earthquake is likely to record a succession of submarine mass movements. Sediment failure at the head of a submarine canyon may begin as a slide or slump, continue as a debris flow, and change into a turbidity current as fluid content increases down slope (Fisher, 1983; Piper and Normark, 2009, p. 358). The dilution may take place at a hydraulic jump near a decrease in gradient (Piper and Savoye, 1993, p. 577; Mulder and others, 1997, p. 323). Alternatively, a slump or debris flow may become a turbidity current without an increase in water content if velocity alone can produce the required turbulence (Kuenen, 1952; Fisher, 1983). A turbidity current may maintain itself by flushing sediment that prior, lesser flows laid down in its path (Parker, 1982; Paull and others, 2005; Johnson and others, 2006). The current may divide at channel bends if its upper part continues overbank while a starved residual stays in the channel (Piper and Normark, 1983; Normark and Reid, 2003; Fildani and others, 2006).

Slides, slumps, debris flows, and turbidity currents form a family of subaqueous mass movements (Middleton and Hampton, 1973). Slides and slumps undergo less internal deformation than debris flows and turbidity currents. Turbidity currents are grouped with 
sediment gravity flows. A sediment gravity flow moves down slope because its unit weight exceeds that of the ambient water. In a debris flow, sediment grains are supported by a cohesive matrix of finer sediment and interstitial fluid. With increasing fluid content and decreasing particle interactions, the flow loses yield strength and becomes first a grain flow, then a fluidized sediment flow, and finally a turbidity current. In a grain flow the sediment is supported by dispersive pressure arising from grain-to-grain interactions; in a fluidized sediment flow the sediment is supported by pore fluid that is escaping upward; and in a turbidity current the sediment is supported by the upward component of fluid turbulence (Covault, 2011).

Large turbidity currents have not been directly observed in the ocean. Their initiation mechanisms, which can include storms and floods, as well as earthquakes, are "poorly understood" (Piper and Normark, 2009, p. 347). The currents were first inferred from submarinecable breaks (Heezen and Ewing, 1952; Heezen and Hollister, 1964). Their behavior has been inferred from depositional products (Kuenen and Migliorini, 1950; Bouma, 1962; Lowe, 1972; Middleton and Hampton, 1973; Bouma and others, 1985; Piper and Savoye, 1993; Ricci-Lucchi, 2003) and from models based on experiments (Middleton, 1993, p. 102-104; Sumner and others, 2008) and physical theory (Garcia and Parker, 1989; Mulder and others, 1997).

A turbidite commonly rests on an erosional base (Middleton, 1993, p. 101) and decreases upward in grain size (Kuenen and Migliorini, 1950). In the textbook sequence of Bouma (1962), the basal unconformity is overlain first by structureless sand, then by parallel-laminated and ripple-laminated sand, and finally by parallel-laminated silt with a cap of massive mud. This sequence records deposition first of bed load that had arrived by sliding, rolling, or saltating and second of suspended sand, silt, and clay that had been supported by fluid turbulence (Lowe, 1982). Turbidites routinely differ from the classic Bouma sequence in Cascadia Channel (Griggs and Kulm, 1970b, p. 1373) and elsewhere (Middleton, 1993, p. 100-101).

Deep-sea turbidites are commonly separated by hemipelagic deposits. The turbidites may contain material of terrestrial or shallow-marine origin, whereas the hemipelagic clays are dominated by the remains of both pelagic and deep-water bottom-dwelling marine organisms. Offshore Washington the deep sea receives cloudy, shelf-derived water at two levels: a nepheloid layer of intermediate depth that tapers over the continental slope, and a bottom nepheloid layer than extends onto the abyssal plain (Carson and others, 1986, p. 10).

Many studies outside Cascadia have linked earthquakes to turbidity currents or their deposits (see examples in table 1). Earthquakes felt in northern California (1906), eastern Canada (1929), Hokkaido, Japan (1983), and Haiti (2010) have been confidently identified as triggering turbidity currents. Preliminary findings differ concerning the prospects for turbidite paleoseismology offshore northern Sumatra.

\section{Turbidite Names}

Turbidites can be named by stratigraphic position, which in turn can serve as grounds for stratigraphic correlation. The monograph and its advance summaries take this convention a step further by building long-distance correlation into turbidite names. For instance, T2 denotes the next-to-last turbidite in cores obtained as much as $1,000 \mathrm{~km}$ apart. The name, though descriptive, embodies the inference that all turbidites labeled T2 record a fault rupture about $1,000 \mathrm{~km}$ long that occurred close to A.D. 1500 (Goldfinger and others, 2008, their fig. 8). A similar mix of description and interpretation is built into the names for the other 18 or 19 turbidites of Holocene age that the monograph ascribes to full-length rupture of the Cascadia plate boundary.

We substitute localized names that make it easier to ask whether a turbidite in one channel represents the same earthquake as a turbidite in another. Thus in place of T2, we use J2 
for the next-to-last turbidite in Juan de Fuca Channel and C2 for the penultimate turbidite in lower Cascadia Channel. The distinction limits the extent of the inferred stratigraphic correlation that the name implies. It resembles, in Cascadia paleoseismology onshore, the naming of stratigraphic units inferred to correlate within a single estuary or lake (Nelson and others, 2006) or among adjoining estuaries (Atwater and others, 2004, p. 341-342).

Do $\mathrm{J} 2$ and $\mathrm{C} 2$ record the same earthquake? Two contrasting answers provide a preview of the main lines of evidence reviewed:

- Answering "yes," the monograph and its advance summaries ascribe J2 and C2 to the same long T2 rupture (northern part sketched, fig. 3A). The coevality is reportedly shown by uniform turbidite counts from tributary flows of roughly equal size (fig. $3 D$ ), similarity among geophysical logs that are akin to strong-motion records (aligned horizontally, fig. 5), and approximate alignment of the generously adjusted radiocarbon ages of like-numbered turbidites (gray rectangles, fig. 8A,C,D). The generously adjusted ages suggest that the most recent great earthquake at Cascadia, in A.D. 1700, followed a recurrence interval that lasted about 200 years along the entire length of the subduction zone.

- Answering "not necessarily," we offer an alternative in which the C2 rupture precedes the J2 rupture by several centuries and the $\mathrm{J} 2$ rupture resembles the more northerly of the two ruptures sketched in figure $3 B$. Discordance of $\mathrm{J} 2$ and $\mathrm{C} 2$ is consistent with uncertain turbidite counts and unequal tributary flows (fig. 3E), divergent matching of geophysical logs that are dominated by sedimentological noise (diagonal lines, fig. 5), and offshore-onshore correlation that uses minimally adjusted turbidite ages (black rectangles, fig. 8D,E). The minimally adjusted ages accord with biological evidence that the 1700 earthquake followed a recurrence interval that lasted about 600 years offshore southern Washington (fig. 8F).

\section{Correlations Deduced from Turbidite Counts}

An earthquake that passes the confluence test of Adams (1990) initiates sediment gravity flows simultaneously in submarine canyons above the fault rupture. The resulting turbidity currents merge at a Y-shaped channel junction, where they continue downstream as a single flow. A series of earthquakes that all pass the test yields identical numbers of turbidites above and below the junction.

The confluence test reportedly shows that the Cascadia plate boundary offshore Washington typically breaks all at once. Adams applied it to Cascadia Channel and its tributaries, using turbidite stratigraphy from the doctoral studies of Griggs (1969) and Barnard (1973). Like Griggs and Kulm (1970b), he found similarities in counts of turbidites younger than the Mazama ash (fig. 3C) - a widespread volcanic ash that was erupted from "Mount Mazama," Oregon (location, fig. 1B) between 7,800 and 7,500 sidereal years ago (Hallett and others, 1997; Zdanowicz and Zielinski, 1999). Adams concluded that post-Mazama turbidity currents typically merged at the junction between two main tributaries, and that they continued together down 300 $\mathrm{km}$ or more of Cascadia Channel. He inferred that 13 such confluent, coeval flows occurred in post-Mazama time, and that each represents a fault rupture that extended, at a minimum, along the 200-km length of the Washington coast (fig. 3A). Goldfinger and others (in press) reiterate this conclusion. They refer to additional cores that contain 13 or 14 post-Mazama turbidites (fig. 3D). They also cite turbidite-by-turbidite correlation by means of geophysical logs (fig. 5) and radiocarbon ages (fig. $8 C, D$ )

We start by reviewing alternatives to the flow paths and turbidite counts previously used in the confluence test. In an alterative view of flow paths, turbidity currents in one branch of the 
Y die out before reaching the main reach of lower Cascadia Channel - the place where their deposits have been assumed to take the confluence test. In an alternative view of turbidite counts, most counts from cores upstream of the junction are clouded by uncertainty about the stratigraphic level of the lowest Mazama ash and about the number of earthquakes that a counted turbidite may represent. These alternatives, if viable, limit the sensitivity of the confluence test to fault-rupture mode off the Washington coast.

\section{Flow Paths}

The confluence in Adams's test is the junction, at the head of Cascadia Channel, of its two trunk tributaries - Juan de Fuca Channel from the north, and the combined outflow from Quinault and Willapa Channels in the south (figs. 2A, 3). This junction is $50 \mathrm{~km}$ west of the foot of the continental slope in the vicinity of core $6508-\mathrm{K} 1$, as confirmed by the updated map of Goldfinger and others (in press, their fig. 2).

The confluence test takes advantage of proximity to fault-rupture areas and supply of new sediment. The tributaries to Cascadia Channel head in canyons that lie directly above probable areas of plate-boundary rupture that have been inferred from heat-flow and geodetic evidence (Hyndman and Rogers, 2010, p. 811). In the late Holocene, the tributaries received sediment of Columbia River provenance that had been reworked northwestward into a silty continental-shelf deposit that Quinault Canyon intercepts (Nittrouer and others, 1979; Nittrouer and Sternberg, 1981; Baker and Hickey, 1986; Sternberg, 1986). The Mazama ash, which blanketed much of the Columbia River drainage basin from an eruptive source in southern Oregon (location, fig. 1B), reached Cascadia Channel by way of the continental shelf and submarine canyons (Nelson and others, 1968). For comparison, ash from the May 1980 eruption of Mount St. Helens, Washington, washed offshore by the Columbia River, moved northwestward on the shelf and reached Quinault Canyon by October 1981 (Healy Ridge and Carson, 1987).

Two flow paths not considered previously may influence the confluence test: (1) backflooding evidenced by turbidites of side valleys off Cascadia Channel and (2) a shortcut hypothesized to connect Quinault Canyon to a middle reach of Juan de Fuca Channel.

\section{Backflooding of Side Valleys}

Holocene turbidity currents in Cascadia Channel backed into as many as three side valleys (fig. 2B, " $b$ "; fig. 4E). The backflooding subverts the confluence test by providing evidence that that Quinault-Willapa flows readily reached lower Cascadia Channel, whereas Juan de Fuca flows did not (see "Inequality Between Juan de Fuca and Quinault-Willapa Flows," below). Additionally, it confounds the counting of turbidites of strictly Juan de Fuca origin in core 6705-6, for this core is from a reach of Juan de Fuca Channel that Quinault-Willapa flows probably ascended.

Direct evidence for backflooding of lower Juan de Fuca Channel is provided by thick, sandy, complex turbidites of core 6705-6 ("c" in fig. 4A,D). In thickness and grain size they have more in common with complex turbidites in Quinault-Willapa cores 6705-1, -4, and -5, and in junction core $6508-\mathrm{K} 1$, than with the thin, muddy turbidites of Juan de Fuca Channel in core 6705-2. They are also thicker than the turbidites in the Juan de Fuca cores M9907-5, -11, and -12 of Goldfinger and others (in press, fig. 19) (gray at upper left in our fig. 4A).

Evidence for backflooding extends downstream from the $6508-\mathrm{K} 1$ junction. An unnamed side valley near latitude $45^{\circ}$ contains Holocene turbidites in core 6705-10. These have the thickness of the post-Mazama turbidites of lower Cascadia Channel (fig. 4D). The unnamed valley is probably an ice-age relict (Carson, 1971, p. 20), although some maps give the 
impression that it remains active today (Adams, 1990, his fig. 1; Goldfinger and others, in press, fig. 51). Backflooding still farther down Cascadia Channel has been documented from the lower reach of Vancouver Valley (Vancouver Sea Valley of Griggs and Kulm, 1970b). This side valley contains at least ten Holocene turbidites $17 \mathrm{~km}$ upvalley from its junction with Cascadia Channel but no Holocene turbidites tens of kilometers farther upvalley (Griggs and Kulm, 1970b, fig. 11 and p. 1376). The Vancouver Valley turbidites of core 6609-27 (figs. 2A, 4D) are about $90 \mathrm{~m}$ higher than the valley's junction with Cascadia Channel.

At least three factors probably helped flows to ascend the three side valleys. First, all three are on the outer side of a channel bend (fig. 2B). A bend can produce a transverse slope on a flow surface; the flow banks as it rounds the bend, its surface rising toward the bend's outer side (Middleton, 1993, p. 92). Such a transverse slope is evidenced by natural levees that are typically $30 \mathrm{~m}$ higher on the outer (west) side of Cascadia Channel than on the east where the channel bends westward between the junction at core 6508-K1 and Vancouver Valley (Griggs and Kulm, 1970b, p. 1363 and fig. 16). Rounding a bend can cause a turbidity current to send most of its sediment overbank as on the Navy Submarine Fan offshore southern California, where the overbank part accounts for an estimated 80 percent of the Holocene turbidite volume (Piper and Normark, 1983).

Second, Cascadia Channel levees were repeatedly overtopped by late Holocene turbidity currents. Post-Mazama turbidites are intercalated with hemipelagic deposits in levee-top cores (Griggs and Kulm, 1970b, p. 1377), including 6705-7 (fig. 4C) and 6705-9, which were collected 86 and $77 \mathrm{~m}$, respectively, above the intervening Cascadia Channel floor. Both contain thin turbidites interbedded with hemipelagic clay. Core 6705-14, from a west-side levee $68 \mathrm{~m}$ above the floor but farther downstream, contains a similar sequence.

Third, turbidity currents can ascend submarine slopes. This capability is known from ancient examples in rocks, modern examples on submarine highs, laboratory experiments, and mathematical simulations (Muck and Underwood, 1990).

\section{Shortcuts from Quinault Canyon to Lower Juan de Fuca Channel}

Did flows originating from Quinault Canyon, taking a shortcut, contaminate the main turbidite sequences previously ascribed to Juan de Fuca Channel alone? According to Barnard (1973, p. 20-30; 1978, fig. 17), Juan de Fuca Channel has a secondary flow path through basins and ridges of the lower continental slope, as do flows exiting Quinault Canyon. The two paths likely merge in a channel that feeds the main stem of Juan de Fuca Channel just beyond the continental slope, $100 \mathrm{~km}$ north of the 6508-K1 junction (figs. 2A,D; $3 E$ ).

Did this routing allow muddy parts of the largest Quinault-derived flows, following the dotted line in the Q profile in figure 2D, to feed Juan de Fuca Channel upstream of cores M990711, M9907-12, 6705-2, and 6705-6? David Piper (Geological Survey of Canada, written commun., 2011) points out that a large Quinault flow, going through a hydraulic jump below headwalls of Quinault Canyon, might thicken by entrainment of seawater near the southward bend in Quinault Channel near core 53-18. From there an upper part of the thickened flow might continue westward along Barnard's secondary path, while a lower residual follows the main channel southward.

\section{Observed Counts}

The confluence test of Adams (1990) compares counts of post-Mazama turbidites above and below the junction of Cascadia Channel's two main active tributaries (fig. 3C). Adams (1990, p. 573) reckoned 14-16 (or as many as 19) post-Mazama turbidites in Juan de Fuca core 
6705-2, 14 in Quinault core 53-18 (Barnard, 1978), 15 in Quinault-Willapa core 6705-5 (Griggs and Kulm, 1970b, table 3), 14 in junction core 6508-K1, and 13 farther downstream in cores 6509-15 and 6609-24.

Goldfinger and others (in press) reported more nearly uniform counts from new cores in Juan de Fuca Channel (M9907-05, -11, -12) and, about $350 \mathrm{~km}$ downstream, in lower Cascadia Channel (M9907-22, -23, -25; locations, fig. 2A,D). They noted 13 or 14 post-Mazama turbidites in the Juan de Fuca cores and 13 in lower Cascadia Channel (fig. 3D).

Adams (1990, p. 574) attributed most or all of the 13 post-Mazama turbidites of lower Cascadia Channel to flows that descended both tributary branches simultaneously. He reasoned that the number of post-Mazama turbidites below the 6508-K1 junction, if produced by discordant flows from the tributaries, would otherwise approach the sum of the tributary counts. Goldfinger and coworkers concurred. "The number of events present above the Mazama ash remains constant between the main tributaries and the main stem" (Goldfinger, 2011, p. 47). "This simple observation demonstrates synchronous triggering of turbidity currents in tributaries whose headwaters are separated by 50-150 km" (Goldfinger and others, 2008, p. 866).

In the alternatives below, the position of the lowest Mazama ash has not been established in several key cores, and complex turbidites may record multiple, discordant flows. Figures 1-3 summarize these possibilities by plotting turbidite counts as ranges or limiting values in some cases and as unknown in others and by flagging counts from sites perched above channel thalwegs. To evaluate the options, it is better to consult the monograph's figures 19 and 24 and our figure 4 , for these depict the stratigraphy from which the counts were derived.

\section{Mazama Datum}

Some of the difficulty with counting post-Mazama turbidites can be traced back to a table of recurrence intervals that Griggs and Kulm (1970b, p. 1375) computed from post-Mazama turbidite counts. Two of the intervals imply that Griggs (1969, p. 37) established the lowest level of the Mazama ash in cores from Juan de Fuca Channel (6705-2) and Quinault-Willapa Channel (6705-5). A third implies that the lowest Mazama-rich turbidite in junction core 6508-K1 is the 13th from top. In Griggs's coarse-fraction analyses or detailed logs, we are unable to find grounds for identifying the lowest Mazama-rich turbidite in cores 6705-2 or 6705-5. In 6705-5, 13 is the probable total for all turbidites of Holocene age (table 2). As for 6508-K1, coarsefraction data of Griggs (1969, appendix III) confirms the presence of Mazama in the 13th turbidite from the top, but notes on Griggs's core log show plenty of ash in the 14th turbidite as well (fig. 4A,B). Adams (1990, p. 573), recognizing these problems, made corrections to turbidite counts for 6705-2 and 6508-K1 but not for 6705-5 (table 2).

Goldfinger and others (in press) found the lowest Mazama ash in many of their cores from Cascadia and Juan de Fuca Channels but not in Juan de Fuca core M9907-05. The reported tally of 13 post-Mazama turbidites in M9907-05 depends on its correlation with M9907-11 and 12 by means of the geophysical logs plotted in figure 5. Given this correlation, the number of post-Mazama turbidites in M9907-05 is in the range 13-20 and depends on interpretation of complex turbidites (next section).

The revised counts in table 2 leave Quinault-Willapa tributaries without secure estimates of the number of large post-Mazama turbidity currents that ran down them. We treat the count of 14 in 6508-K1 as a minimum because this core contains several complex turbidites, each of which may represent either a single earthquake or multiple earthquakes. 


\section{Complex Turbidites}

In the confluence test, distal sites where turbidite counting is straightforward are compared with proximal sites where complex turbidites make such counting difficult. Among the deep-sea channels that head offshore Washington, cores that contain 13 simple post-Mazama turbidites are limited to a distal reach of Cascadia Channel (6609-24, fig. 4B; and M9907-23 and -25). By contrast in upper Cascadia Channel and its tributaries, some turbidites are complex enough to represent more than one triggering earthquake.

Each of two complex turbidites in Quinault-Willapa core 6705-1 contains internal evidence for a hiatus that probably lasted decades or even centuries. This evidence consists of a contact at which bioturbated silty clay is abruptly overlain by sand (unconformity, fig. $4 A$ ). The silty clay, after having been deposited by a turbidity current, was bioturbated before another turbidity current laid down the sand after removing any hemipelagic clay that had accumulated while the burrows were being formed.

Complex turbidites have been sketched from several other cores. Griggs logged one complex turbidite in Quinault-Willapa core 6705-4; two complex turbidites in Juan de Fuca core 6705-6; four complex turbidites in junction core 6508-K1; two complex turbidites with enigmatic fine-grained bases in core $6509-10,130 \mathrm{~km}$ downstream from the junction (interpreted by Griggs and Kulm, 1970b, p. 1372-1373, as evidence for a "pre-phase"); and one complex turbidite high in core 6509-15, another $90 \mathrm{~km}$ farther downstream in lower Cascadia Channel (fig. 4). Goldfinger and others (in press, figs. 19, 20) sketched two Juan de Fuca candidates in piston core M9907-12PC, and they identified one of these as a potentially separate turbidite.

Still other complex turbidites may be present farther up Juan de Fuca Channel, in the upper $1.5 \mathrm{~m}$ of trigger core M9907-05TC. As sketched by Goldfinger and others (in press, Fig. 19), it contains as many as seven silt or sand beds in the middle or upper parts of named turbidites with which they have been lumped (ball and bar symbol, fig. 5). The main basis for this lumping is correlation of geophysical logs with those named turbidites in cores M9907-11 and -12 . The monograph makes clear that this correlation requires assuming that the highest few turbidites are missing from trigger core M9907-05TC but were recovered in the adjacent piston core M9907-05PC. A trigger core usually recovers the topmost deposits more fully than does the adjacent piston core (examples, Piper and Normark, 1983, p. 684).

\section{Time Lags in Cascadia Channel}

Nested within the confluence test may be an internal one: whether flows traveling different distances reached Cascadia Channel at different times. Adams (1990, p. 574) described this possibility but apparently overlooked the evidence that complex turbidites may provide in cores 6508-K1, 6509-10, and 6509-15 ("c" in fig. 4A,B). Do any of these complex turbidites record sequential passage of turbidity currents from different tributaries? Stacked sand beds of differing provenance offshore California illustrate the idea (Goldfinger and others, 2007). But at least three different earthquake scenarios may be difficult to tell apart in a complex turbidite at the 6508-K1 junction:

- Long rupture all along the Washington coast (fig. 3A)—Sediment gravity flows are triggered only during a few minutes of earthquake shaking. A late-arriving Juan de Fuca current, having traveled farthest, builds a thin, silty turbidite atop silty clay that settled out of the tail of a Quinault-Willapa flow. Candidates for such couplets form complex turbidites at backflooded site 6705-6 and at the 6508-K1 junction (fig. 4A). 
- A swift series of ruptures that break this part of the fault (fig. 3B)—Hours, years, or even a few decades separate the individual breaks of adjoining fault patches ("Serial rupture and triggering distance," below).

- A rupture offshore southern Washington that does not extend farther north-Flows traveling various distances from Quinault and Willapa sources yield multiple pulses at the 6508-K1 junction $(Q$ versus $W$, fig. $2 D)$. Coincident flows from the Juan de Fuca side die out upstream of the junction.

The sedimentary record of these scenarios at the 6508-K1 junction would depend on several unknowns that further complicate the confluence test:

- Duration at canyon head-Initiation of sediment gravity flows can continue for hours after an earthquake. Such prolonged initiation has been inferred from retrogressive slumps in the source area of turbidity currents from the 1929 Grand Banks earthquake (Piper and others, 1999).

- Prior flushing of tributaries - Because a turbidity current can maintain itself by entraining sediment along its path (Parker, 1982), whether a flow reaches the 6508-K1 confluence may depend, in part, on the time that has elapsed since the last flushing of the conduit.

- Time lags between canyon and junction-Flows from the most distant Juan de Fuca sources lag their Quinault-Willapa counterparts by 6-8 hours if all are triggered both briefly and synchronously, and if the flow speed averages $20 \mathrm{~km} / \mathrm{hr}$. The most distant of the QuinaultWillapa canyon heads are 120-160 km nearer the head of Cascadia Channel (marked by junction core 6508-K1) than are its Juan de Fuca equivalents (fig. 2D). The top speed inferred by Griggs and Kulm (1970b, p. 1378) is $5.8 \mathrm{~m} / \mathrm{s}(\sim 20 \mathrm{~km} / \mathrm{hr})$. By comparison, the speeds estimated for 1979 Nice turbidity current diminish from about $30 \mathrm{~m} / \mathrm{s}$ at its transformation from a debris flow to about $1-2 \mathrm{~m} / \mathrm{s}$ at its passage onto a nearly flat abyssal plain (Mulder and others, 1997, p. 307, 323).

- Settling from thick flows-The largest post-Mazama flows in Cascadia Channel aggraded natural levees 80-100 $\mathrm{m}$ above the channel thalweg (Griggs and Kulm, 1970b, p. 13761377). Suppose that a Quinault-Willapa flow is $100 \mathrm{~m}$ thick at the 6508-K1 junction. May sediment in the flow's tail settle out before a flow of distant Juan de Fuca origin arrives 6-8 hours later? That it can, in the absence of strong currents, is suggested by findings from a November 1981 storm that swept particles off the continental shelf into Quinault Canyon, where they were collected in sediment traps on the canyon bottom. The particles settled through the water column by 100-200 m/day (Baker and Hickey, 1986, p. 30-31).

- Self-organization of flows - A turbidity current "is more likely to show a simple waning flow history farther from its source; this is because faster-moving parts of the flow overtake slower moving parts, and the flow organizes itself over time so that the fastest parts are at the front" (Kneller and McCaffrey, 2003, p. 706). Such self-organization may help a complex proximal turbidite serve as the record of a single earthquake. But it may also prevent sand beds of the correlative, distal turbidite from serving as a strong-motion record (see "Sedimentary Shredding of Seismological Signals," below).

\section{Inequality Between Juan de Fuca and Quinault-Willapa Flows}

For a tributary channel to be subject to the confluence test of Adams (1990), its sediment gravity flows need the ability to lay down a distinct deposit in Cascadia Channel. Accordingly, Adams (1990, p. 574) asked whether turbidity currents in one or the other of the main Cascadia Channel tributaries petered out above or a short distance below their $6508-\mathrm{K} 1$ junction. He 
discounted the idea on the grounds that it "would require a higher rate of attrition than is evident [from counts of post-Mazama turbidites] in either the upper tributaries or in the lower Cascadia Channel."

Alternatively, Juan de Fuca flows were small as they approached the 6508-K1 junction, in contrast with flows of Quinault-Willapa origin. It was the Quinault-Willapa flows alone that laid down the well-known rhythmic sequences of 13 post-Mazama turbidites of lower Cascadia Channel. Viewed this way, the confluence test loses sensitivity to fault rupture beneath the Juan de Fuca canyon heads offshore northern Washington.

\section{Attrition of Juan de Fuca Flows}

Flows probably were petering out in lower Juan de Fuca Channel as they approached the 6508-K1 junction. The thin, sand-poor turbidites typical of Juan de Fuca core 6705-2 are diminutive compared with the Quinault-Willapa deposits in cores 6705-5, -4, and -1 (fig. 4A). Some of this contrast may result from local facies changes such as those shown by differences downstream between channel-bottom core 6509-15A (fig. 4B) and channel-wall core 6509-15 (fig. 4C). But the turbidites at upstream Juan de Fuca sites M9907-05, -11, and -12 (Goldfinger and others, in press, figs. 19, 24), though sandy, are as thin as those in Juan de Fuca core 6705-2, in contrast with the thick, sandy turbidites of Quinault-Willapa cores 6705-4 and 6705-1 (fig. 4A).

The proposed shortcuts from Quinault Canyon to lower Juan de Fuca Channel may further limit the Cascadia Channel record of flows derived from the upper reaches of Juan de Fuca Channel. The shortcut potentially allowed flows of Quinault origin to reach Juan de Fuca Channel upstream of Juan de Fuca cores M9907-11, M9907-12, 6705-2, and 6705-6 (fig. 2A,D). The more these sites receive turbidity-current sediment from Quinault Canyon, the less Cascadia Channel monitors fault rupture beneath the upper reaches of Juan de Fuca Channel.

\section{Inferred Dominance of Quinault-Willapa Flows}

For flows that ran hundreds of kilometers down Cascadia Channel, a Quinault-Willapa source is evidenced further by signs of backflooding and erosion and by probable paths of Columbia River sediment on the Washington continental shelf.

Evidence presented above suggests that Quinault-Willapa flows backed tens of kilometers up Juan de Fuca Channel from the 6508-K1 junction (fig. 4E). Those flows, unaided by Juan de Fuca input, probably suffice to explain the similar backflooding farther down Cascadia Channel in the side valley of core 6705-10 and in Vancouver Sea Valley.

Erosion can help a large turbidity current maintain its size. Numerical modeling suggests that entrainment of loose sediment from a channel floor increases a current's weight and driving force. The turbidity current then accelerates and entrains additional sediment in a self-reinforcing cycle (Parker and others, 1986). Signs of erosion have been reported from Cascadia Channel's Quinault and Willapa tributaries, and from Cascadia Channel itself, but not from Juan de Fuca Channel. The erosion is evidenced by unconformities within complex turbidites and by thin channel-bottom sections of Holocene deposits. Unconformities confirmed by burrows, mentioned above under "Uncertainties in Turbidite Counts," are present in continental-slope cores 6705-1 and 6705-4 (fig. 4A). Thin Holocene sections are present in continental slope cores 53-19 and 63-08, and they are also present downstream of the 6508-K1 junction, in Cascadia Channel cores 6705-8, 6705-13, 6609-30, and 6609-14 (open circles, figs. 2A,D).

The Washington continental shelf receives most of its sediment from the Columbia River, the largest river on the Pacific coast of North America (Sternberg, 1986). Willapa, Grays, and 
Quinault Canyons are first to intercept Columbia River sediment that moves northward on the shelf (Nittrouer and others, 1979). These canyons, moreover, are closer to Cascadia Channel than are the canyons that feed into Juan de Fuca Channel (distances measured along the main tributary paths, fig. $2 A, D$ ). The Columbia River is a main source of clays, heavy minerals, and volcanic ash in Holocene turbidites of Cascadia Channel (Griggs, 1969, p. 115, 125, and appendix V, VI).

\section{Correlation of Individual Turbidites}

Even without a definitive confluence test, the deep sea offers uncommon opportunities for stratigraphic correlation along the direction of flow. That turbidity currents can run out for hundreds of kilometers was established long ago from cable breaks off Grand Banks (Heezen and Ewing, 1952; Kuenen, 1952) and at Cascadia Channel (fig. 2D) from deep-sea deposits derived from ice-age floods (Griggs and others, 1970; Normark and Reid, 2003). Individual turbidites have been correlated for tens to hundreds of kilometers among deep-sea cores of modern deposits beneath the Mediterranean and North Atlantic, and turbidites have been traced for tens of kilometers among outcrops arrayed parallel to flow direction in the Miocene of Italy (Amy and Talling, 2006, their table 1 and figs. 10-21, 23-27). Individual Holocene turbidites have also been traced for $80 \mathrm{~km}$ parallel to flow among three cores from Cascadia Channel by means of stratigraphically consistent differences in the depth and abundance of animal burrows (Griggs and others, 1969) (location, fig. 2A; burrows sketched, fig. 8F). Profiles of magnetic susceptibility were used to correlate late Holocene turbidites beneath the floor of Lake Washington, just east of Puget Sound (Karlin and others, 2004, Figs. DR1-DR4).

The monograph of Goldfinger and others (in press) uses geophysical logs and adjusted radiocarbon ages to derive turbidite-by-turbidite correlations. This evidence reportedly confirms that 13 post-Mazama turbidites in lower Cascadia Channel record long plate-boundary ruptures that triggered turbidity currents in both of its main tributaries. Reviewing the logs and ages from Cascadia Channel and its tributaries, we find them consistent with additional modes of fault rupture and with an alternative offshore-onshore correlation that improves agreement with earthquake history inferred from estuaries.

\section{Geophysical Logs}

Goldfinger and others (2003, p. 564) did not distinguish between long ruptures and swift series of shorter ruptures. The deep-sea turbidites, as interpreted in 2003 , lacked the time resolution to show whether shaking offshore Washington occurred during the same several minutes as did shaking offshore southern Oregon. Such fine resolution was inferred 5 years later on the basis of geophysical logs (Goldfinger and others, 2008) — wiggly curves of gamma density and magnetic susceptibility.

The monograph likens the curves to seismograms of shaking felt regionally. The peaks of high density and high susceptibility correspond to sandy beds. Each bed represents a persistent sedimentary pulse within a turbidity current. Each sedimentary pulse corresponds to a pulse of strong seismic shaking. Each seismic pulse reached different submarine canyons within the same several minutes of a great or giant plate-boundary earthquake.

In the alternative interpretations below, the monograph's evidence is consistent both with long ruptures and with swift series of shorter ruptures offshore Washington. The observed logs of correlated turbidites contain too few peaks and too much noise for confidence in bed-by-bed correlation. Sediment gravity flows, especially those with long or complicated paths, are 
susceptible to changes, generated by the paths or by the flows themselves, that would obscure or obliterate the signals from pulses of seismic shaking at canyon heads. Individual pulses of strong shaking during great earthquakes, as recently recorded by accelerometers in Chile and Japan, can be traced for only a few hundred kilometers along the fault-rupture length.

\section{Simplicity and Variability of the Inferred Signatures}

The monograph and its advance summaries describe two sets of northern cores as prime examples of correlation by means of gamma density and magnetic susceptibility curves. The sets are M9907-5, -11 and -12 from Juan de Fuca Channel and M9907-22, -23, and -25 from lower Cascadia Channel (locations, figs. 1A, 2A). Their geophysical logs for post-Mazama deposits are reproduced in figure 5. In this figure each post-Mazama turbidite and its hemipelagic cap are represented by a log segment, and each turbidite base is aligned horizontally with its correlates as depicted in figures 19 and 24 of the monograph.

The monograph identifies the deposits of Juan de Fuca and Cascadia Channels as "among the best correlation series." One channel is positioned to feed the other, their numbers of postMazama turbidites are similar, and individual beds within the turbidites have been correlated by means of the geophysical logs. The logs show that "the number of coarse fraction pulses remains the same in nearly all cases."

Alternatively, the geophysical logs show a combination of individual simplicity and local variability that makes long-distance, bed-by-bed correlation difficult (fig. 5). Few of the individual curves contain more than three peaks per turbidite - a simplicity that makes it easy for one turbidite to resemble another. The correlated curves vary locally in their numbers and sizes of peaks, and this local variability is about as great as the differences between the two channels.

On these observational grounds alone, a given peak is difficult to interpret as the geophysical trace of a widely correlatable unit. Also difficult, for reasons discussed next, is relating the peak to a regional pulse of strong seismic shaking.

\section{Sedimentary Shredding of Seismological Signals}

The monograph and its advance summaries take the confluence test of Adams (1990) a sedimentological step farther. Adams envisioned the merger, at the 6508-K1 junction, of turbidity currents delivered synchronously from canyons heading the Juan de Fuca and QuinaultWillapa tributaries of Cascadia Channel. Goldfinger and coworkers propose, in addition, the merger of individual pulses within these coeval flows. This pulse-by-pulse merger "constrains the timing and increases the significance of the stratigraphic correlations in that the structure of the multipulse turbidity current that deposited the multipulse turbidite must have been similar in separate channels above the confluence, and must have survived the merging at the confluence" (Goldfinger and others, 2008, p. 872-873). The inferred sedimentary pulses travel from source to sink: "Given the relatively little observed modification of the deposits between Juan de Fuca Channel to Cascadia Channel, over a distance of $480 \mathrm{~km}$ [from M9907-05 to -22], we suggest that modification by hydrodynamic processes is probably not of primary significance" (Goldfinger and others, in press).

Alternatively, the details of whatever triggers a sediment flow become obscured or obliterated by the time the flow reaches a distant sink. Such internal loss of an external signal, termed "shredding" (Jerolmack and Paola, 2010) or "noisy sediment transport" (Jerolmack, 2011), may be a common problem in interpreting sedimentary deposits. In a nonearthquake example, a river-flood hydrograph with a single broad maximum may yield multiple pulses in a marine turbidity current (Lamb and Mohrig, 2009). Similarly, if an earthquake is the initial 
trigger, the details of its ground motions may be subject to shredding (or shedding) as the subaqueous mass movement begins and as it progresses from canyon-head slide to abyssal turbidity current.

The initiation of subaqueous mass movement may deviate from the details of ground motions by responding to their cumulative effects and by waiting until after the shaking has finished. Landslide potential is commonly related more to the cumulative shaking from an earthquake than to an individual peak in ground motion (Jibson, 1996, p. 310; Jibson, 2007). The same holds for liquefaction (Kayen and Mitchell, 1997; Kramer and Mitchell, 2006), which like many landslides results from elevated pore pressure. As for delays, the retrogressive slumps probably continued for hours as they nourished the turbidity current from the 1929 Grand Banks earthquake (Piper and others, 1999). Intervals of hours to days have elapsed between earthquakes and some of the terrestrial slides they induced (Jibson and others, 1994, p. 967-970). In an instrumented example from southern California, excess pore pressures sufficient for liquefaction lagged the earthquake that raised them (Holzer and others, 1989).

Additional shredding of ground-motion details may await a slide or slump as it transforms downslope (Fisher, 1983; Piper and Normark, 2009, p. 358). The changes include dilution into a turbidity current at a hydraulic jump (Piper and Savoye, 1993, p. 577; Mulder and others, 1997, p. 323), the mechanisms for transferring sediment from the slide or slump to the turbidity current (Mohrig and Marr, 2003), ignition or maintenance of the turbidity current by conduit flushing (Parker, 1982), and vertical partitioning of the turbidity current at channel bends (flow stripping of Piper and Normark, 1983; Normark and Reid, 2003; Fildani and others, 2006).

Suppose an earthquake sets off a slides or slumps in Quinault Canyon. Sedimentary shredding begins there if initiation of the slides or slumps lasts longer than the earthquake does. Even if the initial mass movement manages to synchronize with a series of strong-motion pulses, the resulting sedimentary pulses are likely to undergo dilution by hydraulic jumps, enrichment by conduit flushing, and vertical division by channel bends as the flow proceeds toward lower Cascadia Channel (figs. 1A, 2A,D). An initial sedimentary pulse from multiple canyons may still become a series of pulses by reaching channel junctions at different times (see "Time Lags in Cascadia Channel," above; Trinidad example of Goldfinger and others, in press). A QuinaultWillapa flow alternates between erosion and deposition in the reach between Quinault Canyon and lower Cascadia Channel (see "Inferred Dominance of Quinault-Willapa Flows," above). Along the way it ascends lower Juan de Fuca Channel from the 6508-K1 junction, where it may lay down multiple graded beds (fig. 4A). By the time it reaches lower Cascadia Channel it has reorganized enough to register as a comparatively simple turbidite of cores 6609-24 (fig. 4B) and M9907-22, -23, and -25 (fig. 5).

\section{Along-strike Variation in Seismic Shaking}

In the monograph and its advance summaries, sandy-bed correlation broadly consistent with radiocarbon ages provides the decisive evidence that ruptures offshore Washington extended along most of the rest of the subduction zone as well. The sandy-bed correlations reportedly hold among "channels where the geology, mineralogy, physiography, channel gradients and morphology, sediment sources and transport mechanisms are different." The "fingerprints" identified in geophysical logs "sometimes retain a remarkable similarity at sites along strike but also commonly evolve somewhat along strike in subtle ways that can be traced from one site to another."

The monograph accordingly likens the geophysical logs to strong-motion records of seismic pulses felt widely along strike. The "only plausible commonality between correlative 
turbidites in separate channels is a common earthquake source." The correlative beds "may record elements of the unique shaking signal imparted to the sediment failure region by the earthquake itself, in effect the physical property signatures may be crude 'paleoseismograms', imparting some information about magnitude, source character, or aftershocks to the depositional history of each turbidite. In the case of a subduction zone such as Cascadia, the source may last 3-8 minutes, and may consist of multiple rupture patches linked together, but separated in time by several minutes... Rupture of these source patches imparts a waxing and waning shaking signal to the canyon systems, and may result in multiple turbidity currents initiated within minutes of each other traveling the canyon-channel system to depocenters in the distal channels . . This may be a controversial interpretation, but we are led to it out of a need to explain the observed data."

When this idea was introduced a few years ago (Goldfinger and others, 2008), there was no possibility of testing it against to strong-motion records of earthquakes larger than $M 8.3$. The giant 2004 Aceh-Andaman earthquake had provided far-field seismological evidence for patches of large seismic slip (Chlieh and others, 2007) and high-frequency energy release (Ishii and others, 2007) that does not show how far along-strike, in the near field, strong shaking from the individual patches extended. Strong motions had been measured in Chile during earthquakes in 1985 and 2007, and pulses of strong shaking from these earthquakes have now been ascribed to asperities (Ruiz and others, 2011), but the fault ruptures were less than $200 \mathrm{~km}$ long.

Today, the idea of turbidites as strong-motion records can be tested against along-strike patterns of strong shaking from two patchy ruptures about $500 \mathrm{~km}$ long-from the 2010 Maule, Chile, earthquake of $M 8.8$ and the 2011 Tohoku, Japan, earthquake of $M$ 9.0. The Chilean records show two pulses in the north and a single long pulse in the south. In the seismograms compiled by Boroshek and others (2010, their figs. 3-8), two pulses about 20 seconds apart were recorded at coastal stations Viña and Llolleo, whereas only one pulse is evident farther south at Constitución and Concepción. The two northern pulses, seen also in records from Santiago (Naeim and others, 2011), have been ascribed to asperities in the 2010 rupture (Saragoni and others, 2010), which contained two main areas of high slip (Lorito and others, 2011). But the northern pulses are not distinct in the southern records, which instead show only one long pulse. The Japanese records also vary along the length of the fault rupture. They show two dominant groups of seismic waves about 30 seconds apart in Miyagi and northern Fukushima Prefectures. The second group extends farther south and is followed there by a third group (Furumura and others, 2011b; Ide and others, 2011; Suzuki and others, 2011). The wave groups differ further in their dominant periods, with the main sources of short-period waves being located beneath the coast (Kurahashi and Irikura, 2011; Suzuki and others, 2011) — a complexity also inferred for the Maule earthquake (Koper and others, 2012).

Such spatial patterns would likely confound sandy-bed correlation as a means of showing that fault ruptures at Cascadia extended for more than a few hundred kilometers. Set aside concerns about the correlation of geophysical logs and the sedimentary transmission of seismic signals. Now suppose that a sandy bed correlates $300 \mathrm{~km}$ along strike and that it denotes a widespread pulse of strong motion. Does the bed represent a nearby part of a long rupture or the entirety of a short rupture? Or suppose that a distinctive turbidite is identified along the full length of the Cascadia Subduction Zone, and that it contains more sandy beds in one area than in another. Does the difference mark variation along the strike of a long rupture, like that seen recently in Chile and Japan? Or does it mean that the fault broke piecemeal in a swift series of shorter ruptures (see "Serial Rupture," below)? 


\section{Radiocarbon Ages and Sedimentation Rates}

In the monograph, stratigraphic correlations inferred from turbidite counts and geophysical logs are supported further by adjusted radiocarbon ages. Error terms in the adjusted ages incorporate uncertainties about turbidity-current erosion and hemipelagic sedimentation rates.

Reviewing the age adjustments, we find reasons to expand the error terms for erosion corrections and sedimentation rates. The expanded errors permit variation in rupture mode and alternative offshore-onshore correlations (subsequent sections).

\section{Converting Foraminiferal Ages into Turbidite Ages}

Goldfinger and others (in press) obtained dozens of radiocarbon ages on samples of hundreds of foraminifers from hemipelagic deposits (fig. 6A, step 1). The ages of these foraminifera, including a standard correction for the estimated age of the seawater from which their calcium carbonate was precipitated, provide secure limiting-maximum ages for the overlying turbidites (fig. 8C,D; black boxes with arrows pointing forward in time).

The monograph makes additional adjustments that are intended to bring these limiting ages closer to the times of turbidite deposition. The adjustments are mostly in the range 100-400 sidereal years for the examples considered here from Juan de Fuca and Cascadia Channels (labels in fig. $7 B$; shifts from black boxes to gray boxes in fig. $8 C, D$ ). The parameters are depicted in figure 6 and propagated in figures 7 and 8. They were introduced by Gutierrez-Pastor and others (2009) and further implemented by Goldfinger and others (in press), as follows:

- Hemipelagic thickness, preserved ( $s / 2$ and $p$ )_-Hemipelagic deposits in Cascadia Channel and its tributaries rained out of the water column in the centuries between turbidity currents. The adjustments take into account the thickness of the hemipelagic interval from which the dated foraminifers were separated. It also takes into account the thickness of any hemipelagic deposits that separate it from the overlying turbidite. These parameters are $s / 2$ and $p$, respectively, in figures $6 A$ and $7 A$.

- Hemipelagic thickness, eroded (e)-The adjustments are also intended to account for onceintervening hemipelagic deposits that were eroded by the flow that laid down that overlying turbidite ( $e$, fig. $6 A$, step 2 ). The thickness of the eroded deposits is approximated by correlating each hemipelagic interval among nearby cores (fig. $6 A$ ) and by treating, as uneroded, the interval's thickest example in these cores (thickness $h$, fig. 6A; examples, fig. $6 B)$.

- Sedimentation rate ( $r$ ) - The additional adjustments incorporate estimates of the sedimentation rate, $r$ (fig. 6A, step 3). Gutierrez-Pastor and others (2009) and Goldfinger and others (in press, appendix 1, "Sed rate curve" worksheets) estimated $r$ by dividing hemipelagic thickness $h$ by the difference, TB-TA, between the ages of the two bounding turbidites. TA and TB are so-called full-margin ages without error terms. For instance, in estimating $r$ for lower Cascadia Channel, turbidites $\mathrm{C} 2$ and $\mathrm{C} 3$ are assigned the multiplechannel average ages of turbidites $\mathrm{T} 2$ and $\mathrm{T} 3$, and each of these ages is treated as a single value, not as a range. The computed sedimentation rate $r$ commonly varies from interval to interval. Gutierrez-Pastor and others (2009) and Goldfinger and others (in press, appendix 1) reduced this variability by computing a three-point running average that smoothes the estimates of $r$ across successive recurrence intervals.

The monograph assigns blanket uncertainties of $\pm 0.2 \mathrm{~cm}$ in $s$ and $p, \pm 0.5 \mathrm{~cm}$ in $e$, and \pm 15 percent in $r$ (Goldfinger and others, in press, appendix 1, "RC data" worksheet). Spreadsheet 
entries confirm propagation of the error terms for $s, p$, and $e$. In the alternative adjustments suggested below, larger uncertainties could be assumed and propagated for sedimentation rate $r$ and erosion thickness $e$ in converting foraminiferal ages into turbidite ages for lower Cascadia Channel.

\section{Further Uncertainty About Rates of Hemipelagic Deposition}

There are several reasons to assume that uncertainty in hemipelagic sedimentation rate $r$ exceeds the monograph's \pm 15 percent:

- The hemipelagic-clay thicknesses used to estimate the rate's numerator, $h$ (fig. $6 \mathrm{~A}$, step 3), vary locally by factors of two or more in the examples in figure $6 B$ (details, next section).

- In the rate's denominator, the typical error in ТВ-TA would be the square root of the sum of the squared 2-sigma errors in TA and TB, which individually average 130-140 sidereal years in post-Mazama time (Goldfinger and others, in press, appendix 1, "Land-Marine compilation" worksheet). This error approaches 40 percent of an average recurrence interval 500 years long.

- Additional error in $\mathrm{TB}-\mathrm{TA}$ may result from combining the ages of turbidites that are not coeval. For example, having correlated turbidite C6 with J6, the monograph combines their adjusted ages in dating the widely correlated turbidite T6; but C6 aligns better with $\mathrm{J} 7$ in an alternative correlation inferred below (fig. 8D,E, minimally adjusted ages).

- Little is known about spatial variation in hemipelagic sedimentation in lower Cascadia Channel. The nearest clues are upstream, where shelf-derived sediment forms a cloudy nearbottom layer several hundred meters thick - a bottom nepheloid layer — with particle concentrations as much as three times greater in Willapa Canyon than on the adjoining slope (Baker, 1976b). Similarly, offshore northern Washington, the bottom nepheloid layer is thickest and densest above Juan de Fuca Channel, and Holocene hemipelagic deposits are thicker in the channel than on the adjacent abyssal plain (Stokke and others, 1977). Stokke and coworkers concluded that the cloudy water moves continuously down Juan de Fuca Channel, and that silt-size detritus concentrates and probably rains out there. Does this process extend down Cascadia Channel? Does hemipelagic sedimentation there vary with proximity to the channel wall?

In a probably conservative propagation of these further uncertainties, we doubled the error term for $r$ to \pm 30 percent. The resulting errors are plotted in figure $7 B$. Combined with other errors by using the square root of the sum of the squared errors, the added uncertainty extends each half of a 95-percent confidence interval for turbidite age by an amount that is compared in figure $7 C$ with the lesser amount of the uncertainty propagated in the monograph.

The added uncertainty increases with the size of the hemipelagic adjustment plotted in figure $7 B$. It ranges from a decade or less if that adjustment is under 200 years, through several decades if the hemipelagic adjustment is 300-400 years, to nearly a century for the monograph's hemipelagic adjustment of 680 years for turbidite J8. The hemipelagic adjustments that exceed 240 years contain corrections for erosion of the hemipelagic deposits (fig. 7A). For uncertainty in this erosion correction, figure $7 C$ and figure $8 C, D$ follow the monograph in propagating only the monograph's estimate of $\pm 0.5 \mathrm{~cm}$, which is probably an underestimate in lower Cascadia Channel (see next section). 


\section{Further Uncertainty About the Thickness of Hemipelagic Deposits Lost to Erosion}

Local variability in hemipelagic thickness in lower Cascadia Channel probably pushes the error term for erosion parameter $e$ beyond the quoted $\pm 0.5 \mathrm{~cm}$ and, in some cases, probably adds hundreds of years of uncertainty to turbidite ages. Among cores from lower Cascadia Channel, the hemipelagic intervals from the past 4,000 years that show the greatest variability in thickness are those beneath turbidites $\mathrm{C} 4, \mathrm{C} 6$, and $\mathrm{C} 8$ (fig. $6 \mathrm{~B}$ ). Measured thickness differs more than twofold between trigger core and piston core, both for the hemipelagic interval below turbidite $\mathrm{C} 4$ at site 25 (difference $3.5 \mathrm{~cm}$ ) and beneath $\mathrm{C} 6$ at site 23 (difference $4 \mathrm{~cm}$ ). Thickness also differs more than twofold among measurement methods for the hemipelagic intervals beneath $\mathrm{C} 6$ at site 25 (difference as great as $4 \mathrm{~cm}$ ) and beneath $\mathrm{C} 8$ at site 23 (difference $7.5 \mathrm{~cm}$ ). These differences in thickness correspond to hundreds of years' worth of deposits, given hemipelagic sedimentation rates of 1-2 centimeters per century (100-yr brackets, figs. $6 B, 7 A)$.

The monograph ascribes the core-to-core variability to local differences in erosion by turbidity currents. In an alternative interpretation, the variability also results from coring-induced distortion of the hemipelagic deposits and from the difficulty of measuring the thickness of distorted deposits. Hemipelagic deposits that appear distorted by coring can be seen in core sketches and core photos of Cascadia Channel turbidites 4, 5, and 7 of the monograph's figure 25 . The thicknesses in examples above vary greatly with the measurement method.

If mainly an artifact of coring and measurement, the core-to-core variability in hemipelagic thickness provides hundreds of years of additional leeway in adjustments to the foraminferal ages. That leeway, in turn, permits the offshore-onshore correlation marked by solid lines that link parts $D$ and $E$ of figure 8-an alternative discussed below under "Correlation with onshore evidence in southern Washington and northernmost Oregon."

The monograph appears to offer conflicting estimates of erosion in lower Cascadia Channel. On the one hand, the monograph describes erosion of hemipelagic deposits in lower Cascadia Channel as "minimal or absent due to the distal location." The statement is based on a comparison by Gutierrez-Pastor and others (2009) that showed the summed thickness of Holocene hemipelagic deposits to be about as great inside the channel as on the adjacent abyssal plain. On the other hand, the monograph's erosion index groups lower Cascadia Channel with channels in which hemipelagic deposits were eroded most deeply (Goldfinger and others, in press, Appendix 5). That index is based on local variability in the thickness of correlated hemipelagic deposits, extreme examples of which are plotted in our figure $6 B$.

\section{Serial Rupture}

None of the ruptures inferred in the monograph are serial (Goldfinger and others, in press, their figs. 52, 55). Those from the late Holocene extend greater or lesser distances northward from southern limits offshore northern California. The same holds for the early Holocene ruptures except that their southern limit is offshore Oregon because the California records span less time.

The monograph apparently finds serial rupture incompatible with evidence that multiple canyon heads were shaken at the same time. This is the coevality inferred mainly from the confluence test, geophysical logs, and radiocarbon dating (above), and inferred further from triggering distance (below).

Alternatively, serial ruptures are expectable at Cascadia, and this expectability trumps the turbidite evidence against them. Serial rupture is expectable by geophysical analogies. None of the evidence for coevality, onshore or offshore, suffices to show whether a rupture was long or 
short. Turbidites matched along the subduction zone's strike may correlate as lithostratigraphic units, whether they represent a single long rupture or a series of shorter ones. Whatever Cascadia's mix of long ruptures and serial ruptures, is the turbidite evidence sensitive to it?

\section{Reasons to Expect Serial Rupture}

Cascadia has long been considered capable of serial rupture. A quarter century ago it was likened to subduction zones where series of short ruptures have rebroken areas of long ruptures (Heaton and Hartzell, 1986, p. 702-703): along the Nankai Trough, where the long rupture area of 1707 (Furumura and others, 2011a) broke piecemeal in 1854 and again in the 1940s (Ando, 1975); and offshore Colombia and Ecuador, where the long rupture area of 1906 failed next in the series of shorter ruptures of 1942, 1958, and 1979 (Kanamori and McNally, 1982).

Additional analogies suggest that serial rupture at Cascadia could result from changes in stress. A small increase in stress from the Aceh-Andaman rupture in 2004 may have hastened the adjacent Nias earthquake of 2005 (Nalbant and others, 2005). Similarly, stress changes from Cascadia ruptures may have hastened earthquakes on the northern San Andreas Fault (Goldfinger and others, 2008).

\section{Consistency with Coastal Geology}

Serial rupture at Cascadia has been inferred onshore from a superposed pair of sand sheets at Bradley Lake, southern Oregon (location, fig. 1B). These were interpreted to represent a pair of near-field tsunamis within a half century of one another (Kelsey and others, 2005, p. 1030; Nelson and others, 2006, p. 462).

Long rupture at Cascadia has also been inferred onshore, but the evidence is compatible with serial, shorter ones. Nelson and others (2006) inferred rupture length from similarities in radiocarbon age and in relative amounts of coseismic subsidence and tsunami deposition. They concluded that eight late Holocene ruptures probably extended at least $460 \mathrm{~km}$ from southern Washington to southern Oregon, but series of shorter ruptures can explain the combination of approximate coevality and lithostratigraphic similarity (see Nankai examples under "Stratigraphic Code," below).

A long rupture looked geologically indistinguishable from a swift series of short ruptures in a 1995 attempt to estimate the size of what was soon to become known as the 1700 Cascadia earthquake. Radiocarbon dating showed that tree death from coseismic subsidence had occurred during the same few decades (Nelson and others, 1995) - a time window wider than those of the Japanese and Indonesian rupture series above. It took Japanese accounts of flooding and damage to give confidence that the full 1,100-km length of the Cascadia Subduction Zone can rupture in a single earthquake (Satake and others, 1996; Satake and others, 2003; Atwater and others, 2005). High-slip ruptures less than $500 \mathrm{~km}$ long were found compatible with this far-field evidence but not with amounts or directions of land-level changes at Cascadia estuaries (Satake and others, 2003, their table 4 and section 6).

\section{Triggering Distance}

Triggering distance is the maximum distance between an earthquake source and a place where the earthquake shaking sets off mass movements that yield an abyssal turbidite. Suppose, as assumed by Goldfinger and others $(2008$, p. 873 ), that the triggering distance at Cascadia is 90 $\mathrm{km}$. If a submarine canyon is within $90 \mathrm{~km}$ of the boundary between a pair of contiguous fault ruptures, the canyon in principle yields one turbidite for each rupture. If a sequence of turbidites 
lacks such doublets, no boundary between serial ruptures lies within $90 \mathrm{~km}$ of its channel's upper reaches.

In an alternative view, triggering distance at Cascadia is a range that is specific to place and time and which is still to be determined. It may vary with proximity to steep slopes and canyon heads (fig. 1A), directivity of fault rupture, aftershocks, and recency of conduit flushing. Its stratigraphic records may include complex turbidites from serial ruptures (see "Time lags in Cascadia Channel," above). If it must be quantified, better as a broad range.

\section{Stratigraphic Code}

Turbidites may correlate without being coeval. In a sequence of many successive turbidites, geophysical logs provide numerous peaks that can support correlation of the sequence as a whole without requiring coevality of its parts. The sequence forms a lithostratigraphic unit, like a geologic formation.

Under stratigraphic code (North American Commission on Stratigraphic Nomenclature, 2005), a lithostratigraphic unit is defined without regard for inferred geologic history, though "considerations of well-documented geologic history properly may influence the choice of [its] vertical and lateral boundaries." The unit's definition is also independent from concepts of time, though the sequence boundaries "may be approximately synchronous" and "evidence of age may aid recognition of similar lithostratigraphic units at localities far removed from the type sections or areas."

An individual turbidite, correlated widely as a lithostratigraphic unit, is either synchronous or diachronous. It may represent a single long rupture or multiple shorter ones. In the monograph, one correlated turbidite is distinctly sand rich (T11, which includes C11 and J11) and another is distinctly sand poor (T10). Turbidites assigned to T11 may indeed record an unusually large earthquake like the one from a full-length rupture along the Nankai Trough in 1707. But they may also represent a swift series of shorter ruptures like those that produced, 32 hours apart, the pair of Nankai Trough earthquakes in 1854. Similarly, sand-poor turbidites assigned to T10 may record a pair of lesser earthquakes, like the Nankai pair of 1944 and 1946. As rated in a comprehensive catalog of Japanese earthquakes, the two 1854 earthquakes were 0.5 magnitude units larger, and one Japanese-intensity unit stronger, than were their successors of 1944 and 1946 (Usami, 1996, p. 123, 136, 294, 299).

\section{Correlation with Onshore Evidence in Southern Washington and Northernmost Oregon}

Uncertainties in stratigraphic correlation allow two contrasting scenarios for the next-tolast (penultimate) rupture, or ruptures, of a northern part of the Cascadia plate boundary. Only the second correlates well with evidence onshore.

In the first scenario, advanced by the monograph and its advance summaries, northern Cascadia breaks with most of the rest of the fault in a single long rupture. This rupture yields turbidites $\mathrm{J} 2$ and $\mathrm{C} 2$ and their correlates elsewhere, T2. The T2 earthquake, uncommonly small for its rupture length, has few onshore correlates because these form less readily and get erased more easily than do continuous stratigraphic sequences in the deep sea.

In the second scenario, not considered previously, $\mathrm{J} 2$ records a rupture that was limited to the northernmost part of the subduction zone; $\mathrm{C} 2$ represents a rupture several centuries earlier that originated or reached farther south; and the inferential T2 conflates the two. This alternative improves correlations onshore by agreeing with the geographic distribution of potential onshore correlates of $\mathrm{J} 2$, and by avoiding glaring mismatches between the spread and maturing of forests onshore and the depth and density of burrows offshore. 


\section{Onshore Evidence Correlative with Turbidite J2}

The earthquake inferred from turbidite $\mathrm{J} 2$ probably predates the 1700 Cascadia earthquake by just a few centuries (fig. 8B). It has potential onshore correlates in southern British Columbia and northern Washington but none evident in southern Washington.

The northern onshore provides evidence for subsidence, shaking, and a tsunami with age ranges that overlap with the likely time of $\mathrm{J} 2$. The subsidence is marked by a buried soil near the Pacific coast at Tofino, British Columbia (at site 1 of Clague and Bobrowsky, 1994). The shaking can be inferred from either of two debris flows among varves at Saanich Inlet, British Columbia (deposit 1 or 2 of Blais-Stevens and others, 2011). As for a tsunami, a sand sheet in the $\mathrm{J} 2$ age range is present along the Strait of Juan de Fuca $60 \mathrm{~km}$ inland from the open ocean at Discovery Bay, Washington (Williams and others, 2005) (unit 2 of fig. 8B).

By contrast, buried soils and sand sheets of $\mathrm{J} 2$ age are unknown farther south among widely exposed, well-dated evidence for subsidence, tsunamis, and shaking at estuaries of southern Washington and northernmost Oregon (map, fig. 1B; graph, fig. 8E,F). Western red cedar in southern Washington, though sensitive to salt, lived through J2 time (preserved tree rings; fig. $8 E$ ) but died later from the tidal submergence in the first months after the A.D. 1700 Cascadia earthquake (Jacoby and others, 1997; Yamaguchi and others, 1997).

The penultimate plate-boundary rupture inferred at estuaries of southern Washington and northernmost Oregon predates turbidite $\mathrm{J} 2$. The rupture is evidenced by subsided soil W, which has been difficult to date because it rarely retains growth-position remains of plants that had been rooted in it at the time of subsidence. A liquid-scintillation radiocarbon age on a shrub root in growth position in the uppermost few centimeters of soil W opposite Fort Clatsop, near the mouth of the Columbia River provided a broad two-sigma range of 730-1,140 calibrated years before A.D. 1950 (cal yr BP) (Atwater and others, 2004, p. 349, Beta-121421). Further dating of three bark-bearing roots, probably all from the previously dated shrub, has now yielded accelerator-mass-spectrometry ages of $895 \pm 30,915 \pm 30$, and $990 \pm 35{ }^{14} \mathrm{C}$ yr BP (NOSAMS88065 through -88067$)$. Each of these roots was collected $2 \mathrm{~cm}$ below the top of the soil. Their mean age, $928 \pm 18{ }^{14} \mathrm{C}$ yr BP, corresponds to A.D. 1037-1157 (793-913 cal yr BP) at two standard deviations - distinctly older than $\mathrm{J} 2$ (fig. 8A,E).

The penultimate great earthquake along the southern Washington and northernmost Oregon coast is probably closer in age to $\mathrm{J} 3$ than to $\mathrm{J} 2$, as judged from these new ages and the red-cedar rings (fig. 8C,E). It preceded the 1700 earthquake by about 540-660 years, or by slightly more than the average of the recurrence intervals in figure $8 F$. And if turbidity-current deposition in lower Cascadia Channel records fault rupture offshore southern Washington, the penultimate turbidite in in lower Cascadia Channel, $\mathrm{C} 2$, is probably more similar in age to J3 than to $\mathrm{J} 2$.

\section{Passage of Time Inferred from Burrowed Turbidites and Forested Tidelands}

According to the monograph, the depth and abundance of the preserved burrows of deepsea animals offers an unreliable guide to the relative lengths of earthquake-recurrence intervals. This view accords with the monograph's conclusion that the northern third of the Cascadia plate boundary broke all together just a few centuries before 1700, as part of a long T2 rupture. Reviewing related literature, the monograph cites evidence from elsewhere that deep-sea bioturbation depends on the organic content of the burrowed sediment and need not deepen with time. Further, using cores along the Cascadia Subduction Zone, the monograph compares a bioturbation index with time intervals between the widely correlated earthquakes dated as in 
figure $8 A$ (Goldfinger and others, in press, their table 2). In this comparison, the deep and abundant bioturbation of turbidite $\mathrm{C} 2$ (fig. $8 F$ ) corresponds to the short interval between $\mathrm{T} 2$ and T1 (fig. 8A) in lower Cascadia Channel.

In the alternative earthquake history proposed above, deep and abundant bioturbation corresponds to long recurrence intervals of the past 3,500 years in lower Cascadia Channel, and these intervals correspond to times when tidal-spruce forests expanded in southern Washington and northernmost Oregon (fig. 8D-F). The resulting offshore-onshore correlation supports the conclusion that $\mathrm{C} 2$ preceded $\mathrm{J} 2$ by several centuries, and that the plate boundary offshore southern Washington probably did not break as part of a long T2 rupture around A.D. 1500 .

That some Cascadia Channel turbidites are consistently burrowed more abundantly and deeply than others was recognized more than 40 years ago among three cores along $80 \mathrm{~km}$ of channel length (Griggs and others, 1969; core locations on our fig. 2A). Griggs and others (1969, p. 167) puzzled over this correlatable pattern, illustrated in the lower part of figure $8 F$. They thought the successive turbidites might differ in particle size and organic content but judged them "quite uniform" in these respects and further noted that "no significant change in either is associated with the lower limit of burrow penetration." They also imagined that the burrowing could vary with the time interval between turbidites, but they found time difficult to evaluate in hemipelagic deposits showing signs of erosion.

Those offshore intervals ought to coincide with times between the great plate-boundary earthquakes that have been inferred from buried soils in southern Washington and northernmost Oregon. Such a correlation makes sense because the plane of fault rupture probably responsible for the subsidence of the soils largely underlies the heads of what are likely the main sources of Holocene turbidity currents in lower Cascadia Channel—its Quinault-Willapa tributaries (figs. $1 B, 3 A)$.

The recurrence intervals onshore vary in length among the intervals labeled $\mathrm{J}-\mathrm{L}, \mathrm{L}-\mathrm{N}$, and so on in figure $8 F$. The differences are shown qualitatively by the profiles of soils that developed during the intervals and by the extent and maturity of forests that spread across those soils as they emerged interseismically. The quantified differences are based on radiocarbon dating of the remains of plants the earthquakes killed by means of tidal submergence, probably in the first years after coseismic subsidence (Atwater and others, 2004, p. 339).

Atwater and Hemphill-Haley (1997, p. 100-103) noted that these unequal time intervals onshore appear to align with the unequal depths and densities of bioturbation that Griggs and coworkers had noted offshore. In a current version of this correlation (fig. $8 F$ ), the burrows into turbidite $\mathrm{C} 2$ represent the long onshore interval $\mathrm{W}-\mathrm{Y}$ and correspond to expansion of the forests that the A.D. 1700 earthquake killed.

\section{Consistency with Confluence Test, Geophysical Logs, and Radiocarbon Ages}

In the introduction to this report we highighted the monograph's hypothesis that a rupture around A.D. 1500, extending along the full length of the Washington coast and beyond, produced the next-to-last turbidite in the lower reaches of Juan de Fuca and Cascadia Channels. We proceeded to review the main turbidite evidence for this hypothesis: confluence test, geophysical logs, and radiocarbon dating. We found reasons to retain a previous view in which the plate boundary offshore southern Washington produces no great earthquake around A.D. 1500 .

Checked first were counts of post-Mazama turbidites in the confluence test of Adams (1990). We found that few cores from Juan de Fuca and Cascadia Channels, and none from the Quinault-Willapa tributaries, define the count of post-Mazama turbidites as 13. Further, we 
found that the 13 turbidites of lower Cascadia Channel are probably insensitive to flows from the upper reaches of Juan de Fuca tributaries. We concluded that the next-to-last turbidite of lower Cascadia Channel (C2) probably monitors fault ruptures offshore southern Washington only. A flow in Juan de Fuca Channel may produce a later turbidite (J2) without registering in lower Cascadia Channel.

Turning next to the geophysical logs, we found them difficult to correlate uniquely, let alone to interpret as strong-motion records. In the logs of gamma density, we found that $\mathrm{C} 2$ is not dissimilar to $\mathrm{J} 3$ and $\mathrm{J} 2$ (fig. 5A). In the logs of magnetic susceptibility, we found the peaks too few, and too variable within Cascadia Channel, for strong correlation between the channels. Beyond these observational problems, we wondered whether sediment gravity flows that manage to match pulses of seismic shaking at canyon heads would survive the sedimentary processes that yield a turbidite, and whether a sequence of seismic pulses is likely to correlate more than a few hundred kilometers along the plate boundary's strike.

Finally we dug into the monograph's appendixes for details about radiocarbon ages and erosion corrections. In principle, the dating has the ability to show that Cascadia Channel turbidite $\mathrm{C} 2$ is too young to match either with Juan de Fuca turbidite J3 or with the onshore subsidence marked by soil $\mathrm{W}$. We found instead that the ages and corrections permit the C2-J3 and $\mathrm{C} 2-\mathrm{W}$ matches (fig. 8D-F). The sole foraminiferal age for $\mathrm{C} 2$ is one of the five ages, among the nine Cascadia Channel ages from hemipelagic intervals assigned to the past 4,000 years, that Goldfinger and others (in press, figs. 19, 24) discounted as stratigraphically inconsistent (fig. 8d). Among the four ages retained, three have been shifted forward by 360-390 years (gray ranges for $\mathrm{C} 8$, C6, and C4, fig. 8D), mainly to correct for erosion estimates that may be compromised by deformation from coring (fig. $6 \mathrm{E}$ ). Smaller, plausible corrections for erosion allow C6 and C4 to correlate with coastal events $\mathrm{L}$ and $\mathrm{S}$, respectively (solid lines linking fig. $8 D$ and $E$ ). These correlations, by leaving room for offshore $\mathrm{C} 3$ to correlate with onshore $\mathrm{U}$, permit $\mathrm{C} 2$ to correlate with $\mathrm{J} 3$ and $\mathrm{W}$. Juan de Fuca turbidite $\mathrm{J} 2$ then marks a later rupture offshore northern Washington that did not extend farther south.

\section{Consistency with Coastal Land-Level Changes}

The relative ages of turbidites $\mathrm{J} 2$ and $\mathrm{C} 2$ may bear on a geographic difference in amounts of subsidence during the 1700 Cascadia earthquake. The amounts were estimated mainly from studies of microfossils within and above subsided soils. The estimates are about half as large for Tofino, British Columbia (Guilbault and others, 1995; Guilbault and others, 1996; Hughes and others, 2002), as they are for estuaries in southwest Washington (Shennan and others, 1996; Atwater and Hemphill-Haley, 1997, p. 83) (locations, fig. 1B).

The difference presents a quandary regarding the length of the recurrence interval that the 1700 earthquake ended (Leonard and others, 2010). The Tofino subsidence corresponds to 200 years' worth of accumulated strain from plate convergence, whereas the southwest Washington subsidence represents more than 500 years' worth. If turbidites J2 and C2 both represent a fullmargin T2 earthquake that occurred about 200 years before A.D. 1700, the Tofino subsidence is easier to explain than the southwest Washington subsidence. The large amount of A.D. 1700 subsidence in southwest Washington might be explained by analogy with the giant 1960 Chile earthquake (Leonard and others, 2010, p. 2087), in which the average slip exceeded the plate convergence of the preceding recurrence interval (Stein and others, 1986; Cisternas and others, 2005).

The alternative earthquake history proposed here solves the quandary more simply. It preserves the short recurrence interval before the 1700 earthquake at the latitude of Tofino by 
leaving $\mathrm{J} 2$ young, while providing a long recurrence interval offshore southern Washington that begins with a C2 earthquake in the range A.D. 1000-1200.

\section{Mud Turbidites}

Turbidite-based estimates of great-earthquake frequency at Cascadia have evolved since Goldfinger and others (2003) reported evidence for 13 post-Mazama earthquakes offshore both Washington and southern Oregon. Today, the in-press monograph gives the total as 30 or 31 offshore southern Oregon while leaving the Washington (lower Cascadia Channel) tally at 13 (fig. 1A).

These new earthquake rates for southern Cascadia exceed those inferred onshore. Among the post-Mazama earthquakes now inferred from the Rogue cores offshore southern Oregon, 14 date from the past 3,000 years (Goldfinger and others, in press, fig. 52). By contrast the number of great plate-boundary earthquakes inferred for the past 3,000 years is 7 or 8 in southern Oregon (Nelson and others, 2006, p. 356) and 5 or 6 in northern California (Peterson and others, 2011).

What mainly accounts for these differences are sand-poor or sand-free beds that had been previously lumped with hemipelagic mud. First reported in 2008 (Goldfinger and others, 2008, p. 871), they have been called mud turbidites. Few are easy to see in the monograph's core photos, and many are also invisible in its geophysical logs. What they mean for earthquake hazards depends on whether they are limited to southern Cascadia and on whether they represent great plate-boundary earthquakes.

\section{Apparent Absence Offshore Washington}

Texts of the monograph and its advance summaries treat mud turbidites as scarce or absent in channels that head offshore southern British Columbia and Washington. Hyndman and Rogers (2010, p. 806) accordingly stated, "There is little evidence for additional events in the northern part offshore Washington and southern Vancouver Island.” More attention could be given to the northern evidence that has been found and to physiography as a reason for its sparseness.

Muddy turbidites have been reported offshore Washington from a wall of Quinault Canyon and the floor of Juan de Fuca Channel. Barnard (1973, p. 162; 1978, p. 111) counted 14 turbidites of post-Mazama age in Quinault core 53-18 (location, fig. 2A,D), 12 of which he logged as sandy and 2 of which he logged as silt (table 2). Goldfinger and others (in press, figs. 19,20) sketched silty beds in complex turbidites of Juan de Fuca cores M9907-05TC and M9907$12 \mathrm{TC}$ (fig. 5, table 2). Griggs noted coarse-silt partings in thick hemipelagic units farther down Juan de Fuca Channel (fig. 4A, at a depth of 1-2 $\mathrm{m}$ in core 6705-6).

Gentle slopes and a broad continental shelf may put northern Cascadia cores at a disadvantage in the recording of small sediment gravity flows (fig. 1). The monograph's key cores in the Cascadia Channel system are situated tens to hundreds of kilometers down-channel from submarine canyon heads that indent the broad continental shelf offshore Washington (M9907-11, -12, -22, -23, and -25). By contrast, most of the core sites offshore southern Oregon and northern California adjoin steeper slopes and a narrower continental shelf (Rogue, Smith, Klamath, Trinidad, and Eel).

\section{Initiation of Flows Offshore Oregon and Northern California}

What triggered the flows that deposited mud turbidites at the foot of steep slopes offshore Oregon and California? The monograph, weighing various explanations for them, cites 
sedimentology, stratigraphic correlation, and infrequent recurrence as reasons to invoke great earthquakes in all cases offshore Oregon and in many cases offshore northern California.

The appendix in this report continues the discussion. It considers three main alternatives: (1) regionally heavy winters during which fluid mud moves across the continental shelf, (2) outbursts from landslide-dammed lakes, and (3) moderate earthquakes on other faults or on the plate boundary itself.

\section{Recommendations for Mapping of Seismic Hazards}

Deep-sea turbidites command attention as guides to the sizes and rates of great earthquakes at the Cascadia subduction zone. No other paleoseismological evidence shows as much potential for quantifying earthquake hazards through reconstruction of earthquake histories going back 10,000 years or more. This potential is already widely known from advance summaries of the monograph of Goldfinger and others (in press). How much weight should the monograph's findings receive in current efforts to update national seismic-hazard maps?

According to turbidite paleoseismology we review in this report, rupture along most or all the length of the Cascadia Subduction Zone produces $M 9$ earthquakes at intervals averaging about 500 years. In addition, southern parts of the zone are inferred to face the further hazard of additional, lesser earthquakes that halve the average interval between earthquakes of $M$ 8-9. These interpretations provide, for the first time, size and rate estimates that cover the entire length of the subduction zone. Further, the turbidite evidence commonly spans twice as much time as does the coastal evidence for great Cascadia earthquakes. The turbidite evidence has thus provided grounds for estimates of tsunami size (Priest and others, 2010) and for statistical tests of patterns in earthquake recurrence (Goldfinger and others, in press).

Alternatively, turbidite evidence need not warrant much redrawing of seismic-hazard maps at this time. Our review provides three reasons for such caution. First, although turbidite evidence provides grounds for inferring a prevalence of $M 9$ earthquakes along the southern Washington part of the subduction zone, it does so more convincingly by confirming an average recurrence interval of about 500 years for turbidity currents in lower Cascadia Channel, than by suggesting simultaneous shaking of multiple canyon heads. Second, prevalence of infrequent $M$ 9 earthquakes need not extend to the plate boundary offshore northern Washington and southern British Columbia, where earthquake-recurrence intervals may average as little as 300 years. Third, turbidite paleoseismology at the Cascadia Subduction Zone could be clarified through greater attention to turbidite sedimentology and chronological uncertainty.

\section{Earthquakes of $M 9$ offshore Southern Washington and Beyond}

In 1996, U.S. National Seismic Hazard Maps began treating the Cascadia plate boundary as a source of two kinds of earthquakes: (1) giant earthquakes of about $M 9.0$ from rupture along most or all of the subduction zone, and (2) lesser but still great earthquakes of $M 8.0$ and larger from shorter ruptures. Each of these two earthquake types formed a branch in a so-called logic tree of the hazards that the mapmakers incorporated. For the 1996 maps the full length of the subduction zone was judged half as likely to break in giant earthquakes as in earthquakes that are merely great (Frankel and others, 1996). Since then the weights have shifted: in 2002, giant and great earthquakes received equal weight (Frankel and others, 2002); in 2008, giant earthquakes received twice the weight of merely great earthquakes (Petersen and others, 2008). Turbidite paleoseismology apparently contributed to this shift; Frankel and Peterson (2008, p. K1) cited 
the findings of Goldfinger and others (2003) as "evidence that great earthquakes usually rupture most of the Cascadia subduction interface."

The evidence reviewed here, onshore as well as offshore, places few constraints on the mixes of long and short ruptures that have included the plate-boundary off the Washington coast. The 13 post-Mazama turbidites of lower Cascadia Channel are probably sensitive to fault rupture offshore southern Washington only. The turbidites include records of long ruptures (fig. 3A), like the long A.D. 1700 rupture inferred with help from written records in Japan (Satake and others, 2003), but these turbidites can also be explained by shorter ruptures (fig. 3B) within uncertainties of the confluence test, geophysical logs, and radiocarbon ages reviewed here. Stronger paleoseismological cases for $M 9$ earthquakes offshore southern Washington depend on the Japanese evidence from 1700 and on an average recurrence interval, estimated both offshore and onshore, of about 500 years. The 5-century interval, in combination with plate convergence at 4 $\mathrm{m}$ per century, allows for a total slip of $20 \mathrm{~m}$ if seismic slip accounts for all the plate convergence.

Even with reliable geological estimates of the length of a Cascadia plate-boundary rupture, earthquake size may be difficult to estimate from rupture length alone. The difficulty is shown by the compactness of the plate-boundary rupture that produced the giant 2011 Tohoku earthquake. Maximum seismic slip on the order of $50 \mathrm{~m}$ helped this earthquake attain magnitude 9 despite a rupture length of about $500 \mathrm{~km}$ (Ide and others, 2011; Suzuki and others, 2011; Yamazaki and others, 2011; Yue and Lay, 2011). For the giant A.D. 1700 Cascadia earthquake, such combinations of slip and rupture length at Cascadia can explain the historical accounts of flooding and damage in Japan but appeared, as of 2003, to be inconsistent with the sense and amounts of coseismic deformation inferred from paleoecological estimates of before-and-after land levels at Cascadia estuaries (Satake and others, 2003). Additional paleoecology (Hawkes and others, 2011), along with tsunami models fit to tsunami geology (MacInnes and others, 2010), may help clarify the possibility of compact giant earthquakes at Cascadia.

Uncertainties in the geophysical logs limit their usefulness in estimating the relative sizes of earthquakes. Measuring the areas under gamma-density spikes, Goldfinger and others (in press) derived a parameter they called "scaled turbidite mass." They used it to check correlation between Juan de Fuca core M9907-12PC and Cascadia Channel core M9907-23PC (Goldfinger, 2011, p. 53-54) and to relate the relative size of an earthquake to the lengths of the recurrence intervals that preceded and followed it (Goldfinger and others, in press, figs. 60-62). This reliance on single cores neglects the variability in gamma density among nearby cores that is evident in figure $5 A$. The use of scaled turbidite mass as a guide to relative earthquake size may be further complicated by sedimentological controls on turbidity-current size, such as the prior history of erosion and deposition in conduits that a flow flushes.

\section{Earthquake Recurrence Offshore Southern British Columbia and Northern Washington}

During the past 2,500 years, the Cascadia plate boundary may have broken more often offshore southern British Columbia and northern Washington than offshore southern Washington. Northern turbidites J5 and J2 were each deposited during a long southern recurrence interval inferred from onshore geology (intervals N-S and W-Y, respectively; fig. $8 B, F$ ). The earlier of these long intervals has also been inferred from turbidites T6 and T5 (fig. $8 D)$.

A greater frequency of far-northern plate-boundary earthquakes would help explain the roughly 300-year average interval between inferred tsunamis at Discovery Bay, northern Washington. Williams and others (2005) correlated several of these tsunamis with southern 
Washington coseismic subsidence plotted in figure $8 E$. They assigned the remainder, including tsunamis 2 and 3 in figure $8 A$, to hypothetical tsunami sources other than the plate boundary-to faulting in the North America plate beneath the Strait of Juan de Fuca and northern Puget Sound. But as pointed out by Goldfinger and others (in press), one could just as well invoke independent rupture of the plate boundary off the mouth of the Strait.

It may be early to conclude that the deep sea off Washington lacks muddy gravity-flow deposits like those offshore southern Oregon and northern California. They might be sought in the vicinity of Juan de Fuca Channel core M9907-05, for it contains several candidates (bar-andball symbol, fig. 5). Such deposits might also be sought through surveys that build on Barnard's $(1973 ; 1978)$ studies of continental-slope basins offshore Washington and that target sites as near to steep slopes and canyon heads as those of the southern Cascadia cores (fig. 1A).

\section{Further Research}

Greater attention to sedimentology and uncertainty may help improve the quantification of earthquake hazards at the Cascadia Subduction Zone by means of deep-sea turbidite evidence.

\section{Relating Turbidites to Earthquakes}

Further attention to sedimentology could aid in clarifying the earthquake history that is embedded in the turbidite history. Specific objectives could include:

- Seeking criteria for identifying the deposits of sediment gravity flows that were initiated apart from great earthquakes, especially those deposits resembling the mud turbidites offshore Oregon and northern California;

- Tagging turbidites by level of confidence in inferring that they represent earthquakes;

- Investigating complex turbidites for subtle signs of time breaks between serial earthquakes;

- Anchoring seismological inferences in modern analogs by comparing turbidites offshore central Chile and northeast Japan with nearby strong-motion records of the 2010 Maule and 2011 Tohoku earthquakes.

Outsiders might help through sedimentological study of existing cores. Onshore paleoseismology at Cascadia gained credibility as disparate groups reached similar conclusions. Opportunities for such comparison may be afforded by debris-flow evidence for earthquakes in annually laminated deposits beneath a fjord near Tofino, British Columbia (Dallimore and others, 2005; Dallimore and others, 2008; Hay and others, 2009).

An experiment on the sedimentary shedding of seismological signals could build on the two-part legacy of turbidite studies of Cascadia Channel and its tributaries. Whether individual sedimentary pulses persist from canyon-head source to distal-channel sink might be tested by combining cores at least as numerous and diversely sited as those from the 1960s (fig. 2A) with modern profiling and logging methods reviewed by Goldfinger (2011, p. 52). Specific goals could include learning whether flows from upper reaches of Juan de Channel aggraded lower Cascadia Channel (fig. 3); whether flows from Quinault Canyon used the shortcut (discussed above) to lower Juan de Fuca Channel (fig. 2A,D); and whether routine flows primed the conduit of catastrophic flows, as has been inferred for the Navy Submarine Fan (Piper and Normark, 1983, p. 691) and Monterey Canyon (Johnson and others, 2006).

Sedimentology also has a role in evaluating mud turbidites as evidence for the inferred doubling of great-earthquake rates offshore southern Oregon and northern California. Attention could focus on how physiography affects runout distances (fig. 1A), on whether the mud represents turbidity currents, and on triggers apart from great plate-boundary earthquakes 
(appendix). In addition, the mud turbidites need fuller depiction than they receive in the monograph's photos and geophysical logs, and their correlation from channel to channel could be revisited in light of uncertainties in correlation by means of geophysical logs and radiocarbon ages from Juan de Fuca Channel and Cascadia Channel.

\section{Putting Numbers on Hazards}

With its extensive coverage in space and time, turbidite evidence along the Cascadia Subduction Zone is helping to meet demand for numerical estimates of earthquake and tsunami hazards. The estimates could be improved by measuring and expressing uncertainty more fully than has been done to date, as in the following suggestions:

- Clarify counts of post-Mazama turbidites by using archived cores to fill important gaps in Griggs's (1969) analyses of volcanic ash (fig. 4);

- Display complete sets of geophysical logs in uncluttered diagrams that help readers assess the uniqueness and local variability of correlated curves, as in figure 5;

- Plot adjustments to foraminiferal ages, as in figures 6-8, to make the associated uncertainties more apparent than they are in the monograph's appendix 1;

- Using full uncertainties, rebuild turbidite chronologies channel-by-channel, compare them with the aid of local names, and use the results to help reassess estimates of earthquake size and frequency.

\section{Acknowledgments and Author Responsibilities}

The November 2010 workshop was convened by Arthur Frankel and hosted by Chris Goldfinger (Frankel, 2011). John Adams helped Atwater with pre-workshop discussions and with copies of some of Griggs's core logs. Ann Morey provided additional logs to Griggs. Colleagues whose comments improved the report include Jacob Covault, James Hendley, Samuel Johnson, Harvey Kelsey, Patricia McCrory, Alan Nelson, James Phipps, David Piper, Uri ten Brink, Kelin Wang, Craig Weaver, and Ivan Wong. Atwater prepared most of the manuscript, and Griggs contributed the previously unpublished findings in figure 4.

\section{Appendix-Generating Mud Turbidites Apart from Great Earthquakes}

The monograph of Goldfinger and others (in press) interprets the so-called mud turbidites offshore Oregon as proxy records of great plate-boundary earthquakes, and the monograph makes the same interpretation for many of the mud turbidites offshore northern California as well. These interpretations halve the average recurrence interval for great plate-boundary earthquakes along the southern half of the Cascadia Subduction Zone.

This appendix asks whether turbidity currents laid down these deposits, and whether the flows were triggered apart from great plate-boundary earthquakes. Alternative triggers considered include heavy winters, episodic hillslope failures, dam-break floods, moderate earthquakes, and fluid expulsion.

Muddy gravity flows-Did the mud settle out of a turbidity current, in which the upward component of fluid turbulence supports the particles? Or was it deposited by another kind of sediment gravity flow, in which abundant mud dampened fluid turbulence and enhanced interparticle cohesion?

Heavy winters - A heavy winter in 1997-98 produced a bottom-hugging flow of fluid mud that crossed the continental shelf offshore northern California (Traykovski and others, 2000; Puig and others, 2004; Guerra and others, 2006) and spilled into the upper reaches of Eel Canyon 
(Mullenbach and others, 2004). Such a winter, felt regionally, might produce muddy gravity flows in multiple submarine canyons. These deposits would then correlate among the canyons, much as if the deposits had been produced by regional seismic shaking.

For deposits that extend beyond canyon mouths, the monograph uses frequency of occurrence to help distinguish between heavy winters and seismic shaking (Goldfinger and others, in press). A heavy winter ordinarily fails to ignite catastrophic flows that reach the abyssal core sites along the Cascadia Subduction Zone. Centuries' worth of hemipelagic deposits typically bracket a mud turbidite offshore southern Oregon. During those centures, heavy-winter deposits may prime a canyon for flushing. But it takes an earthquake to set off the catastrophic flow. Such catastrophic triggering by infrequent earthquakes has also been inferred from differences in extent among turbidites of the Navy Submarine Fan offshore southern California and of Monterey Canyon offshore central California (Piper and Normark, 1983; Johnson and others, 2006).

The frequency criterion might be evaluated further by asking how long a canyon may accumulate heavy-winter deposits before these become unstable enough to flush themselves, and by considering terrestrial sources that yield most of their sediment in episodes centuries apart. Earthflows in the drainage basin of the Eel River in California are inferred to activate after dormant periods centuries long (Mackey and Roering, 2011). Similarly in the Oregon Coast Ranges, debris flows flush colluvium from hollows after it has built up for centuries (Benda and Dunne, 1997), and forest fires centuries apart may help trigger the episodic erosion (Jackson and Roering, 2009, p. 1140-1141).

Dam-break floods-Infrequent suppliers of terrestrial sediment also include outbursts from lakes that have been dammed by landslides. Hundreds of examples of landslide-dammed lakes have been documented worldwide (Korup, 2002).

A dam-break flood about six centuries ago originated at The Bridge of the Gods. The name derives from a Native American legend about walking across the Columbia River in an area $150 \mathrm{~km}$ east of the Pacific coast. The legend corresponds to a landslide that dammed this mighty river in the 15th century A.D. (O'Connor, 2004). An ensuing outburst likely accounts for a unit of gray mud commonly a few centimeters thick that coated tidal marshes of the Columbia River estuary, 30-60 km from the coast, several decades before they were blanketed by waterborne ash and pumice from an A.D. 1479 eruption of Mount St. Helens (Takada and Atwater, 2004, p. 555 and appendix A). The gray mud is thicker and more widespread than any other in Columbia River tidal-marsh sections that span the past 1,000 years.

Dam-break floods may also have occurred farther south along the Cascadia Subduction Zone. A river basin in the northern Oregon Ranges contains alluvial fills inferred to have formed behind landslide dams (Turner and others, 2007). Deep-seated landslides cover much of the southern Oregon Coast Ranges and flank the Rogue River (Burns and others, 2011). A lake with an estimated volume of 1.3 million cubic meters backed up behind a landslide dam across the Eel River about 22,000 years ago (Mackey and others, 2010).

A flood can convert directly into a turbidity current by being denser than the seawater that it enters (Mulder and Syvitski, 1995). Alternatively, it may form a surficial plume that delivers unusually large amounts of sediment to the shelf and beyond.

Moderate earthquakes and fluid expulsion-Moderate earthquakes and fluid expulsion may complicate the paleoseismology of mud turbidites in a basin offshore central Oregon. The basin adjoins Hydrate Ridge, which crests about $20 \mathrm{~km}$ east of the foot of the continental slope. Its deposits are bathymetrically isolated from the continental shelf (fig. 1A), and they provide the 
sole turbidite evidence for earthquake shaking along the $400-\mathrm{km}$ stretch between Astoria Canyon and Rogue Canyon (fig. 1B).

Potential triggers for sediment gravity flows into Hydrate Ridge basin include regional earthquakes, local earthquakes, destabilization of gas hydrates, and self-induced failure of bottom sediment (Goldfinger and others, in press). The case for regional shaking rests on stratigraphic correlation with deposits derived from Rogue Canyon; sandy turbidites have been correlated by means of geophysical logs and radiocarbon ages, intervening mud turbidites by their fit within this framework (Goldfinger and others, in press, figs. 30, 45). Local earthquake sources in the vicinity of Hydrate Ridge include the Alvin Canyon Fault, which projects into the ridge; the Daisy Bank Fault, passing $10 \mathrm{~km}$ to the north; and a thrust fault inferred to core the ridge itself (Johnson and others, 2003, p. 82-84). The Alvin Canyon and Daisy Bank Faults, with average slip rates $4-8 \mathrm{~mm} / \mathrm{yr}$, are among nine left-lateral faults active in the past half-million years at the foot of the continental slope offshore of Washington and Oregon (Goldfinger and others, 1996; Goldfinger and others, 1997). Local earthquakes approaching $M 5$ occurred $70 \mathrm{~km}$ to the east of Hydrate Ridge in 2004, apparently on the plate boundary (Williams and others, 2011). Evidence for fluid expulsion is common on the ridge, and mud volcanoes have been mapped near the crest, although not on its basin-facing slopes (Johnson and others, 2003, fig. 9).

\section{References Cited}

Adams, J., 1990, Paleoseismicity of the Cascadia subduction zone-Evidence from turbidites off the Oregon-Washington margin: Tectonics, v. 9, no. 4, p. 569-583.

Amy, L.A., and Talling, P.J., 2006, Anatomy of turbidites and linked debrites based on long distance $(120 \times 30 \mathrm{~km})$ bed correlation, Marnoso Arenacea Formation, Northern Apennines, Italy: Sedimentology, v. 53, no. 1, p. 161-212, doi:10.1111/j.13653091.2005.00756.x.

Ando, M., and Balazs, E.I., 1979, Geodetic evidence for aseismic subduction of the Juan de Fuca Plate: Journal of Geophysical Research, v. 84, no. B6, p. 3023-3028.

Ando, M., 1975, Source mechanisms and tectonic significance of historical earthquakes along the Nankai Trough, Japan: Tectonophysics, v. 27, no. 2, p. 119-140.

Atwater, B.F., and Hemphill-Haley, E., 1997, Recurrence intervals for great earthquakes of the past 3,500 years at northeastern Willapa Bay, Washington: U.S. Geological Survey Professional Paper 1576, 108 p., http://pubs.usgs.gov/pp/1576/.

Atwater, B.F., Tuttle, M.P., Schweig, E.S., III, Rubin, C.M., Yamaguchi, D.K., and HemphillHaley, E., 2004, Earthquake recurrence inferred from paleoseismology, in Gillespie, A.R., Porter, S.C., and Atwater, B.F., eds., The Quaternary Period in the United States, Elsevier, p. 331-350.

Atwater, B.F., Musumi-Rokkaku, S., Satake, K., Tsuji, Y., Ueda, K., and Yamaguchi, D.K., 2005, The orphan tsunami of 1700 - Japanese clues to a parent earthquake in North America: U.S. Geological Survey Professional Paper 1707, 133 p. (Also available at http://pubs.usgs.gov/pp/pp1707/.)

Bagnold, R.A., 1962, Auto-suspension of transported sediment; turbidity currents: Proceedings of the Royal Society of London; Series A-Mathematical and Physical Sciences, v. 265, no. 1322 , p. 315-319.

Baker, E.T., 1976a, Temporal and spatial variability of bottom nepheloid layer over a deep-sea fan: Marine Geology, v. 21, no. 2, p. 67-79. 
Baker, E.T., 1976b, Distribution, composition, and transport of suspended particulate matter in vicinity of Willapa Submarine Canyon, Washington: Geological Society of America Bulletin, v. 87, no. 4, p. 625-632.

Baker, E.T., and Hickey, B.M., 1986, Contemporary sedimentation processes in and around an active West Coast submarine canyon: Marine Geology, v. 71, no. 1-2, p. 15-34, doi:10.1016/0025-3227(86)90031-9.

Barnard, W.D., 1978, The Washington continental slope; Quaternary tectonics and sedimentation: Marine Geology, v. 27, no. 1-2, p. 79-114.

Barnard, W.D., 1973, Late Cenozoic sedimentation on the Washington continental slope: Seattle, University of Washington, Ph.D. dissertation, $255 \mathrm{p}$.

Beck, C., Mercier, d.L., Schneider, J., Cremer, M., Cagatay, N., Wendenbaum, E., Boutareaud, S., Menot, G., Schmidt, S., Weber, O., Eris, K., Armijo, R., Meyer, B., Pondard, N., Gutscher, M., Turon, J.L., Labeyrie, L., Cortijo, E., Gallet, Y., Bouquerel, H., Gorur, N., Gervais, A., Castera, M.H., Londeix, L., de Resseguier, A., and Jaouen, A., 2007, Late Quaternary co-seismic sedimentation in the Sea of Marmara's deep basins: Sedimentary Geology, v. 199, no. 1-2, p. 65-89, doi:10.1016/j.sedgeo.2005.12.031.

Benda, L., and Dunne, T., 1997, Stochastic forcing of sediment routing and storage in channel networks: Water Resources Research, v. 33, no. 12, p. 2865-2880, doi:10.1029/97WR02387.

Blais-Stevens, A., Rogers, G.C., and Clague, J.J., 2011, A revised earthquake chronology for the last 4,000 years inferred from varve-bounded debris-flow deposits beneath an inlet near Victoria, British Columbia: Bulletin of the Seismological Society of America, v. 101, no. 1, p. $1-12$.

Boroschek, R., Soto, P., and Leon, R., 2010, Maule region earthquake February 27, $2010 \mathrm{Mw}=$ 8.8: Renadic Report 10/08 rev. 2, 100 p., accessed February 25, 2012, at http://www.renadic.cl/red_archivos/RENAMAULE2010IR2.pdf.

Bouma, A.H., 1962, Sedimentology of some Flysch deposits; a graphic approach to facies interpretation: Amsterdam and New York, Elsevier, 168 p.

Bouma, A.H., Normark, W.R., and Barnes, N.E., 1985, Submarine fans and related turbidite systems: New York, Springer Verlag, 351 p.

Bourget, J., Zaragosi, S., Ellouz-Zimmermann, S., Ducassou, E., Prins, M.A., Garlan, T., Lanfumey, V., Schneider, J.L., Rouillard, P., and Giraudeau, J., 2010, Highstand vs. lowstand turbidite system growth in the Makran active margin; imprints of highfrequency external controls on sediment delivery mechanisms to deep water systems: Marine Geology, v. 274, no. 1-4, p. 187-208, doi:10.1016/j.margeo.2010.04.005.

Burns, W.J., Mickelson, K.A., and Saint-Pierre, E.C., 2011, SLIDO-2, statewide landslide information layer for Oregon, release 2: Oregon Department of Geology and Mineral Industries, Digital Data Series, http://www.oregongeology.org/pubs/dds/p-slido2.htm, accessed February 25, 2012.

Carson, B., 1971, Stratigraphy and depositional history of Quaternary sediments in northern Cascadia Basin and Juan de Fuca Abyssal Plain, northeast Pacific Ocean: Seattle, University of Washington, Ph.D. dissertation, $249 \mathrm{p}$.

Carson, B., Baker, E.T., Hickey, B.M., Nittrouer, C.A., DeMaster, D.J., Thorbjarnarson, K.W., and Snyder, G.W., 1986, Modern sediment dispersal and accumulation in Quinault submarine canyon-A summary: Marine Geology, v. 71, no. 1-2, p. 1-13, doi:10.1016/0025-3227(86)90030-7. 
Chlieh, M., Avouac, J., Hjorleifsdottir, V., Song, T.A., Ji, C., Sieh, K., Sladen, A., Hebert, H., Prawirodirdjo, L., Bock, Y., and Galetzka, J., 2007, Coseismic slip and afterslip of the great Mw 9.15 Sumatra-Andaman earthquake of 2004-The 2004 Sumatra-Andaman earthquake and the Indian Ocean tsunami: Bulletin of the Seismological Society of America, v. 97, no. 1A, p. S152-S173, doi:10.1785/0120050631.

Cisternas, M., Atwater, B.F., Torrejon, F., Sawai, Y., Machuca, G., Lagos, M., Eipert, A., Youlton, C., Salgado, I., Kamataki, T., Shishikura, M., Rajendran, C.P., Malik, J.K., Rizal, Y., and Husni, M., 2005, Predecessors of the giant 1960 Chile earthquake: Nature, v. 437, no. 7057, p. 404-407, doi:10.1038/nature03943.

Clague, J.J., and Bobrowsky, P.T., 1994, Evidence for a large earthquake and tsunami 100-400 years ago on western Vancouver Island, British Columbia: Quaternary Research, v. 41, no. 2, p. 176-184.

Covault, J.A., 2011, Submarine fans and canyon-channel systems-A review of processes, products, and models: Nature Education Knowledge, v. 2, no. 12, p. 4.

Dallimore, A., Thomson, R.E., and Bertram, M.A., 2005, Modern to late Holocene deposition in an anoxic fjord on the west coast of Canada; implications for regional oceanography, climate and paleoseismic history: Marine Geology, v. 219, no. 1, p. 47-69, doi:10.1016/j.margeo.2005.05.003.

Dallimore, A., Enkin, R., Pienitz, R., Southon, J., Baker, J., Wright, C., Pedersen, T., Calvert, S., Ivanochko, T., and Thomson, R., 2008, Postglacial evolution of a Pacific coastal fjord in British Columbia, Canada - Interactions of sea-level change, crustal response, and environmental fluctuations; results from MONA core MD02-2494: Canadian Journal of Earth Sciences, v. 45, p. 1345-1362.

Fildani, A., Normark, W.R., Kostic, S., and Parker, G., 2006, Channel formation by flow stripping; large-scale scour features along the Monterey East Channel and their relation to sediment waves: Sedimentology, v. 53, no. 6, p. 1265-1287, doi:10.1111/j.13653091.2006.00812.x.

Fisher, R.V., 1983, Flow transformations in sediment gravity flows: Geology, v. 11, no. 5, p. $273-274$.

Frankel, A.D., 2011, Summary of meeting to evaluate Cascadia turbidite data for the National Seismic Hazard Maps: U.S. Geological Survey Open-File Report 2011-1310, 13 p., accessed February 25, 2012, at http://pubs.usgs.gov/of/2011/1310/.

Frankel, A., Mueller, C., Barnhard, T., Perkins, D., Leyendecker, E.V., Dickman, N., Hanson, S., and Hopper, M., 1996, National seismic-hazard maps-Documentation June 1996: U.S. Geological Survey Open-File Report 96-532, 71 p., accessed February 25, 2012, at http://earthquake.usgs.gov/hazards/products/conterminous/1996/documentation/.

Frankel, A.D., Petersen, M.D., Mueller, C.S., Haller, K.M., Wheeler, R.L., Leyendecker, E.V., Wesson, R.L., Harmsen, S.C., Perkins, D.M., and Rukstales, K.S., 2002, Documentation for the 2002 update of the National Seismic-Hazard Maps: U.S. Geological Survey OpenFile Report 02-420, 33 p., accessed February 25, 2012, at http://pubs.usgs.gov/of/2002/ofr-02-420/.

Frankel, A.D., and Petersen, M.D., 2008, Cascadia subduction zone, in Documentation for the 2008 update of the United States National Seismic Hazard Maps: U.S. Geological Survey Open-File Report 2008-1128, p. K1-K3, accessed February 25, 2012, at http://pubs.usgs.gov/of/2008/1128/. 
Furumura, T., Imai, K., and Maeda, T., 2011a, A revised tsunami source model for the 1707 Hoei earthquake and simulation of tsunami inundation of Ryujin Lake, Kyushu, Japan: Journal of Geophysical Research, v. 116, p. B02308, doi:10.1029/2010JB007918.

Furumura, T., Takemura, S., Noguchi, S., Takemoto, T., Maeda, T., Iwai, K., and Padhy, S., $2011 \mathrm{~b}$, Strong ground motions from the 2011 off-the Pacific-Coast-of-Tohoku, Japan $\left(M_{\mathrm{w}}=9.0\right)$ earthquake obtained from a dense nationwide seismic network: Landslides, $\mathrm{v}$. 8, no. 3, p. 333-338.

Garcia, M., and Parker, G., 1989, Experiments on hydraulic jumps in turbidity currents near a canyon-fan transition: Science, v. 245, no. 4916, p. 393-396.

Goldfinger, C., 2009, Subaqueous paleoseismology, in McCalpin, J.P., ed., Paleoseismology: Burlington, Mass., Academic Press, p. 119-170.

Goldfinger, C., 2011, Submarine paleoseismology based on turbidite records: Annual Review of Marine Science, v. 3, p. 35-66, doi:10.1146/annurev-marine-120709-142852.

Goldfinger, C., Kulm, L.D., Yeats, R.S., Appelgate, B., MacKay, M.E., and Cochrane, G.R., 1996, Active strike-slip faulting and folding of the Cascadia subduction-zone plate boundary and forearc in central and northern Oregon, in Rogers, A.M., Walsh, T.J., Kockelman, W.J. and Priest, G.R., eds., Assessing earthquake hazards and reducing risk in the Pacific Northwest: U.S. Geological Survey Professional Paper 1560, p. 223-256.

Goldfinger, C., Kulm, L.D., Yeats, R.S., McNeill, L., and Hummon, C., 1997, Oblique strike-slip faulting of the central Cascadia submarine forearc: Journal of Geophysical Research, v. 102, p. 8217-8243, doi:10.1029/96JB02655.

Goldfinger, C., Nelson, C.H., Johnson, J.E., Erickson, D., Winkler, M., Kalk, P., Pastor, J., Camarero, A., Morri, C., Dunhill, G., Ramos, L., Raab, A., Pisias, N.,Jr, Pourmanoutscheri, M., van Rooij, D., Amy, L., and Liu, C.C., 2003, Holocene earthquake records from the Cascadia subduction zone and northern San Andreas Fault based on precise dating of offshore turbidites: Annual Review of Earth and Planetary Sciences, v. 31, p. 555-577.

Goldfinger, C., Morey, A.E., Johnson, J.E., Chaytor, J., Eriksson, A., Nelson, C.H., GutierrezPastor, J., and Karabanov, E., 2007, Rupture lengths and temporal history of significant earthquakes on the offshore and north coast segments of the Northern San Andreas Fault based on turbidite stratigraphy: Earth and Planetary Science Letters, v. 254, no. 1-2, p. 927.

Goldfinger, C., Grijalva, K., Burgmann, R., Morey, A.E., Johnson, J.E., Nelson, C.H., GutierrezPastor, J., Ericsson, A., Karabanov, E., Chaytor, J.D., Patton, J., and Gracia, E., 2008, Late Holocene rupture of the northern San Andreas Fault and possible stress linkage to the Cascadia Subduction Zone: Bulletin of the Seismological Society of America, v. 98, no. 2, p. 861-889, doi:10.1785/0120060411.

Goldfinger, C., Patton, J., Morey, A., and Nelson, C.H., 2009, Reply to "Comment on 'Late Holocene Rupture of the Northern San Andreas Fault and Possible Stress Linkage to the Cascadia Subduction Zone' by Chris Goldfinger, Kelly Grijalva, Roland Burgmann, Ann E. Morey, Joel E. Johnson, C. Hans Nelson, Julia Gutierrez-Pastor, Andrew Ericsson, Eugene Karabanov, Jason D. Chaytor, Jason Patton, and Eulalia Gracia” by Ganapathy Shanmugam: Bulletin of the Seismological Society of America, v. 99, no. 4, p. 25992606, doi:10.1785/0120080297. 
Goldfinger, C., Nelson, C.H., Johnson, J.E., Morey, A.E., Guitérrez-Pastor, J., Karabanov, E., Eriksson, A.T., Gràcia, E., Dunhill, G., Patton, J., Enkin, R., Dallimore, A., Vallier, T., and Shipboard Scientific Parties, in press, Turbidite event history-Methods and implications for Holocene paleoseismicity of the Cascadia Subduction Zone: U.S. Geological Survey Professional Paper 1661-F, [draft downloaded August 1, 2011, url last accessed February 25, 2012, at http://activetectonics.coas.oregonstate.edu/Goldfinger_1661.zip].

Gràcia, E., Vizcaino, A., Escutia, C., Asioli, A., Rodés, Á., Pallàs, R., Garcia-Orellana, J., Lebreiro, S., and Goldfinger, C., 2010, Holocene earthquake record offshore Portugal (SW Iberia): testing turbidite paleoseismology in a slow-convergence margin: Quaternary Science Reviews, v. 29, no. 9-10, p. 1156-1172, doi:10.1016/j.quascirev.2010.01.010.

Griggs, G.B., 1969, Cascadia Channel: the anatomy of a deep-sea channel: Corvallis, Oregon State University, Ph.D. dissertation, 183 p.

Griggs, G.B., 2011, 1965-The recovery of the first ocean floor evidence of great Cascadia subduction zone earthquakes: Eos (Transactions, American Geophysical Union), v. 92, no. 39 , p. 325-326.

Griggs, G.B., and Kulm, L.D., 1970a, Physiography of Cascadia deep-sea channel: Northwest Science, v. 44, no. 2, p. 82-94.

Griggs, G.B., and Kulm, L.D., 1970b, Sedimentation in Cascadia deep-sea channel: Geological Society of America Bulletin, v. 81, no. 5, p. 1361-1384.

Griggs, G.B., Carey Jr., A.G., and Kulm, L.D., 1969, Deep-sea sedimentation and sedimentfauna interaction in Cascadia Channel and on Cascadia Abyssal Plain: Deep Sea Research and Oceanographic Abstracts, v. 16, no. 2, p. 157-170, doi:10.1016/00117471(69)90071-0.

Griggs, G.B., Kulm, L.D., Waters, A.C., and Fowler, G.A., 1970, Deep-sea gravel from Cascadia Channel: Journal of Geology, v. 78, no. 5, p. 611-619.

Guerra, J.V., Ogston, A.S., and Sternberg, R.W., 2006, Winter variability of physical processes and sediment-transport events on the Eel River shelf, northern California: Continental Shelf Research, v. 26, no. 17-18, p. 2050-2072, doi:10.1016/j.csr.2006.07.002.

Guilbault, J., Clague, J.J., and Lapointe, M., 1995, Amount of subsidence during a late Holocene earthquake; evidence from fossil tidal marsh foraminifera at Vancouver Island, west coast of Canada: Palaeogeography, Palaeoclimatology, Palaeoecology, v. 118, no. 1-2, p. 49-71.

Guilbault, J., Clague, J.J., and Lapointe, M., 1996, Foraminiferal evidence for the amount of coseismic subsidence during a late Holocene earthquake on Vancouver Island, west coast of Canada: Quaternary Science Reviews, v. 15, no. 8-9, p. 913-937.

Gutierrez-Pastor, J., Nelson, C.H., Goldfinger, C., Johnson, J.E., Escutia, C., Eriksson, A., and Morey, A.E., 2009, Earthquake control of Holocene turbidite frequency confirmed by hemipelagic sedimentation chronology on the Cascadia and Northern California active continental margins, in Kneller, B., Martinsen, O.J., and McCaffrey, B., eds., External controls on deep-water depositional systems: Tulsa, Okla., Society for Sedimentary Geology Special Publication 92, p. 179-197.

Hagstrum, J.T., Atwater, B.F., and Sherrod, B.L., 2004, Paleomagnetic correlation of late Holocene earthquakes among estuaries in Washington and Oregon: Geochemistry, Geophysics, Geosystems, v. 5, no. 10, p. 18, doi:10.1029/2004GC000736. 
Hallett, D.J., Hills, L.V., and Clague, J.J., 1997, New accelerator mass spectrometry radiocarbon ages for the Mazama tephra layer from Kootenay National Park, British Columbia, Canada: Canadian Journal of Earth Sciences, v. 34, no. 9, p. 1202-1209, doi:10.1139/e17-096.

Hawkes, A.D., Horton, B.P., Nelson, A.R., Vane, C.H., and Sawai, Y., 2011, Coastal subsidence in Oregon, USA, during the giant Cascadia earthquake of AD 1700: Quaternary Science Reviews, v. 30, no. 3-4, p. 364-376, doi:10.1016/j.quascirev.2010.11.017.

Hay, M.B., Calvert, S.E., Pienitz, R., Dallimore, A., Thomson, R.E., and Baumgartner, T.R., 2009, Geochemical and diatom signatures of bottom water renewal events in Effingham Inlet, British Columbia (Canada): Marine Geology, v. 262, no. 1-4, p. 50-61, doi:10.1016/j.margeo.2009.03.004.

Healy Ridge, M.J., and Carson, B., 1987, Sediment transport on the Washington continental shelf: Estimates of dispersal rates from Mount St. Helens ash: Continental Shelf Research, v. 7, no. 7, p. 759-772, doi:10.1016/0278-4343(87)90015-X.

Heaton, T.H., and Hartzell, S.H., 1986, Source characteristics of hypothetical subduction earthquakes in the northwestern United States: Bulletin of the Seismological Society of America, v. 76, no. 3, p. 675-708.

Heaton, T.H., and Hartzell, S.H., 1987, Earthquake hazards on the Cascadia subduction zone: Science, v. 236, no. 4798, p. 162-168.

Heezen, B.C., and Ewing, W.M., 1952, Turbidity currents and submarine slumps, and the 1929 Grand Banks earthquake: American Journal of Science, v. 250, no. 12, p. 849-873, doi:10.2475/ajs.250.12.849.

Heezen, B.C., and Hollister, C., 1964, Deep-sea current evidence from abyssal sediments: Marine Geology, v. 1, no. 2, p. 141-174.

Holzer, T.L., Youd, T.L., and Hanks, T.C., 1989, Dynamics of liquefaction during the 1987 Superstition Hills, California, earthquake: Science, v. 244, no. 4900, p. 56-59.

Hughes, J.F., Mathewes, R.W., and Clague, J.J., 2002, Use of pollen and vascular plants to estimate coseismic subsidence at a tidal marsh near Tofino, British Columbia: Palaeogeography, Palaeoclimatology, Palaeoecology, v. 185, no. 1-2, p. 145-161.

Hyndman, R., and Rogers, G., 2010, Great earthquakes on Canada's west coast: a review: Canadian Journal of Earth Sciences, v. 47, p. 801-820.

Ide, S., Baltay, A., and Beroza, G.C., 2011, Shallow dynamic overshoot and energetic deep rupture in the $2011 \mathrm{Mw} 9.0$ Tohoku-oki earthquake: Science, v. 332, no. 6036, p. 14261429.

Ishii, M., Shearer, P.M., Houston, H., and Vidale, J.E., 2007, Teleseismic P wave imaging of the 26 December 2004 Sumatra-Andaman and 28 March 2005 Sumatra earthquake ruptures using the Hi-net array: Journal of Geophysical Research, v. 112, p. B11307, doi:10.1029/2006JB004700.

Jackson, M., and Roering, J.J., 2009, Post-fire geomorphic response in steep, forested landscapes: Oregon Coast Range, USA: Quaternary Science Reviews, v. 28, no. 11-12, p. 1131-1146, doi:10.1016/j.quascirev.2008.05.003.

Jacoby, G.C., Bunker, D.E., and Benson, B.E., 1997, Tree-ring evidence for an A.D. 1700 Cascadia earthquake in Washington and northern Oregon: Geology, v. 25, no. 11, p. 9991002, doi:10.1130/0091-7613(1997)025<0999:TREFAA>2.3.CO;2.

Jerolmack, D.J., 2011, Causes and effects of noise in landscape dynamics: Eos (Transactions, American Geophysical Union), v. 92, no. 44, p. 385-386. 
Jerolmack, D.J., and Paola, C., 2010, Shredding of environmental signals by sediment transport: Geophysical Research Letters, v. 37, no. 19, p. L19401, doi:10.1029/2010GL044638.

Jibson, R.W., Prentice, C.S., Borissoff, B.A., Rogozhin, E.A., and Langer, C.J., 1994, Some observations of landslides triggered by the 29 April 1991 Racha earthquake, Republic of Georgia: Bulletin of the Seismological Society of America, v. 84, no. 4, p. 963-973.

Jibson, R.W., 1996, Use of landslides for paleoseismic analysis: Engineering Geology, v. 43, no. 4, p. 291-323.

Jibson, R.W., 2007, Regression models for estimating coseismic landslide displacement: Engineering Geology, v. 91, no. 2-4, p. 209-218, doi:10.1016/j.enggeo.2007.01.013.

Johnson, J.E., Goldfinger, C., and Suess, E., 2003, Geophysical constraints on the surface distribution of authigenic carbonates across the Hydrate Ridge region, Cascadia margin: Marine Geology, v. 202, no. 1-2, p. 79-120, doi:10.1016/S0025-3227(03)00268-8.

Johnson, J.E., Paull, C.K., Normark, W., and Ussler, W., 2006, The extent and recurrence of Holocene turbidity currents in Monterey Canyon and fan channel, offshore California [abs]: Eos (Transactions, American Geophysical Union), v. 87, no. 52, Fall Meeting Supplement, p. abstract OS14A-06.

Kanamori, H., and McNally, K.C., 1982, Variable rupture mode of the subduction zone along the Ecuador-Colombia coast: Bulletin of the Seismological Society of America, v. 72, no. 4, p. 1241-1253.

Karlin, R.E., Holmes, M., Abella, S.E.B., and Sylwester, R., 2004, Holocene landslides and a 3500-year record of Pacific Northwest earthquakes from sediments in Lake Washington: Geological Society of America Bulletin, v. 116, no. 1-2, p. 94-108, doi:10.1130/B25158.1.

Kastens, K.A., 1984, Earthquakes as a triggering mechanism for debris flows and turbidites on the Calabrian Ridge: Marine Geology, v. 55, no. 1-2, p. 13-33, doi:10.1016/00253227(84)90130-0.

Kayen, R.E., and Mitchell, J.K., 1997, Assessment of liquefaction potential during earthquakes by Arias intensity: Journal of Geotechnical and Geoenvironmental Engineering, v. 123, no. 12, p. 1162-1174, doi:10.1061/(ASCE)1090-0241(1997)123:12(1162).

Kelsey, H.M., Nelson, A.R., Hemphill-Haley, E., and Witter, R.C., 2005, Tsunami history of an Oregon coastal lake reveals a $4600 \mathrm{yr}$ record of great earthquakes on the Cascadia subduction zone: Geological Society of America Bulletin, v. 117, no. 7-8, p. 1009-1032, doi:10.1130/B25452.1.

Kneller, B.C., and McCaffrey, W.D., 2003, The interpretation of vertical sequences in turbidite beds: The influence of longitudinal flow structure: Journal of Sedimentary Research, v. 73, no. 5, p. 706-713.

Koper, K.D., Hutko, A.R., Lay, T., and Sufri, O., 2012, Imaging short-period seismic radiation from the 27 February 2010 Chile $\left(M_{\mathrm{W}} 8.8\right)$ earthquake by back-projection of $\mathrm{P}, \mathrm{PP}$, and PKIKP waves: Journal of Geophysical Research, v. 117, p. B02308, doi:10.1029/2011JB008576.

Korup, O., 2002, Recent research on landslide dams - a literature review with special attention to New Zealand: Progress in Physical Geography, v. 26, no. 2, p. 206-235, doi:10.1191/0309133302pp333ra.

Kramer, S.L., and Mitchell, R.A., 2006, Ground motion intensity measures for liquefaction hazard evaluation: Earthquake Spectra, v. 22, no. 2, p. 413-438, doi:10.1193/1.2194970. 
Kuenen, P.H., 1952, Estimated size of the Grand Banks turbidity current: American Journal of Science, v. 250, no. $12 ; 12$, p. 874-884.

Kuenen, P.H., and Migliorini, C.I., 1950, Turbidity currents as a cause of graded bedding: Journal of Geology, v. 58, no. 2, p. 91-127.

Kurahashi, S., and Irikura, K., 2011, Source model for generating strong ground motions during the 2011 off the Pacific coast of Tohoku earthquake: Earth, Planets and Space, v. 63, no. 7, p. 571-576, doi:10.5047/eps.2011.06.044.

Lamb, M.P., and Mohrig, D., 2009, Do hyperpycnal-flow deposits record river-flood dynamics?: Geology, v. 37, no. 12, p. 1067-1070, doi:10.1130/G30286A.1.

Leonard, L.J., Currie, C.A., Mazzotti, S., and Hyndman, R.D., 2010, Rupture area and displacement of past Cascadia great earthquakes from coastal coseismic subsidence: Geological Society of America Bulletin, v. 122, no. 11-12, p. 2079-2096, doi:10.1130/B30108.1.

Lorito, S., Romano, F., Atzori, S., Tong, X., Avallone, A., McCloskey, J., Cocco, M., Boschi, E., and Piatanesi, A., 2011, Limited overlap between the seismic gap and coseismic slip of the great 2010 Chile earthquake: Nature Geoscience, v. 4, no. 3, p. 173-177.

Lowe, D.R., 1972, Implications of three submarine mass-movement deposits, Cretaceous, Sacramento Valley, California: Journal of Sedimentary Petrology, v. 42, no. 1, p. 89-101, doi:10.1306/74D7249B-2B21-11D7-8648000102C1865D.

Lowe, D.R., 1982, Sediment gravity flows; II, Depositional models with special reference to the deposits of high-density turbidity currents: Journal of Sedimentary Petrology, v. 52, no. 1, p. 279-297.

MacInnes, B.T., Weiss, R., Bourgeois, J., and Pinegina, T.K., 2010, Slip distribution of the 1952 Kamchatka great earthquake based on near-field tsunami deposits and historical records: Bulletin of the Seismological Society of America, v. 100, no. 4, p. 1695-1709, doi:10.1785/0120090376.

Mackey, B., Roering, J., and Lamb, M.P., 2010, Evidence for a large landslide-dammed paleolake on the Eel River, California; implications for anadromous fish migration, offshore sedimentation, and landscape evolution [abs]: Geological Society of America, Abstracts with Programs, v. 42, no. 5, p. 612.

Mackey, B.H., and Roering, J.J., 2011, Sediment yield, spatial characteristics, and the long-term evolution of active earthflows determined from airborne LiDAR and historical aerial photographs, Eel River, California: Geological Society of America Bulletin, v. 123, no. 7-8, p. 1560-1576, doi:10.1130/B30306.1.

McHugh, C.M.G., Seeber, L., Cormier, M., Dutton, J., Cagatay, N., Polonia, A., Ryan, W.B.F., and Gorur, N., 2006, Submarine earthquake geology along the North Anatolia Fault in the Marmara Sea, Turkey; a model for transform basin sedimentation: Earth and Planetary Science Letters, v. 248, no. 3-4, p. 661-684, doi:10.1016/j.epsl.2006.05.038.

McHugh, C.M., Seeber, L., Braudy, N., Cormier, M., Davis, M.B., Diebold, J.B., Dieudonne, N., Douilly, R., Gulick, S.P.S., Hornbach, M.J., Johnson, H.E.I.,II, Mishkin, K.R., Sorlien, C.C., Steckler, M.S., Symithe, S.J., and Templeton, J., 2011, Offshore sedimentary effects of the 12 January 2010 Haiti earthquake: Geology, v. 39, no. 8, p. 723-726, doi:10.1130/G31815.1.

Middleton, G.V., 1993, Sediment deposition from turbidity currents: Annual Review of Earth and Planetary Sciences, v. 21, p. 89-114. 
Middleton, G.V., and Hampton, M.A., 1973, Sediment gravity flows; mechanics of flow and deposition, in Middleton, G.V., Bouma, A.H., eds., Turbidites and deep-water sedimentation: lecture notes for a short course: Los Angeles, Calif., Society of Economic Paleontologists and Mineralogists, Pacific Section, p. 1-38.

Mohrig, D., and Marr, J.G., 2003, Constraining the efficiency of turbidity current generation from submarine debris flows and slides using laboratory experiments: Marine and Petroleum Geology, v. 20, no. 6-8, p. 883-899, doi:10.1016/j.marpetgeo.2003.03.002.

Muck, M.T., and Underwood, M.B., 1990, Upslope flow of turbidity currents-A comparison among field observations, theory, and laboratory models: Geology, v. 18, no. 1, p. 54-57, doi:10.1130/0091-7613(1990)018<0054:UFOTCA>2.3.CO;2.

Mulder, T., and Syvitski, J.P.M., 1995, Turbidity currents generated at river mouths during exceptional discharges to the world oceans: Journal of Geology, v. 103, no. 3, p. 285299.

Mulder, T., Savoye, B., and Syvitski, J.P.M., 1997, Numerical modelling of a mid-sized gravity flow-The 1979 Nice turbidity current (dynamics, processes, sediment budget and seafloor impact): Sedimentology, v. 44, no. 2, p. 305-326.

Mullenbach, B.L., Nittrouer, C.A., Puig, P., and Orange, D.L., 2004, Sediment deposition in a modern submarine canyon: Eel Canyon, northern California: Marine Geology, v. 211, no. 1-2, p. 101-119.

Naeim, F., Lew, M., Carpenter, L.D., Youssef, N.F., Rojas, F., Saragoni, G.R., and Adaros, M.S., 2011, Performance of tall buildings in Santiago, Chile during the 27 February 2010 offshore Maule, Chile earthquake: The Structural Design of Tall and Special Buildings, v. 20, no. 1, p. 1-16, doi:10.1002/tal.675.

Nakajima, T., and Kanai, Y., 2000, Sedimentary features of seismoturbidites triggered by the 1983 and older historical earthquakes in the eastern margin of the Japan Sea: Sedimentary Geology, v. 135, no. 1-4, p. 1-19, doi:10.1016/S0037-0738(00)00059-2.

Nalbant, S.S., Steacy, S., Sieh, K., Natawidjaja, D., and McCloskey, J., 2005, Earthquake risk on the Sunda Trench: Nature, v. 435, no. 7043, p. 756-757.

Nelson, C.H., Kulm, L.D., Carlson, P.R., and Duncan, J.R., 1968, Mazama ash in the northeastern Pacific: Science, v. 161, no. 3836, p. 47-49.

Nelson, A.R., Atwater, B.F., Bobrowsky, P.T., Bradley, L., Clague, J.J., Carver, G.A., Darienzo, M.E., Grant, W.C., Krueger, H.W., Sparks, R.J., Stafford, T.W., and Stuiver, M., 1995, Radiocarbon evidence for extensive plate-boundary rupture about 300 years ago at the Cascadia subduction zone: Nature, v. 378, no. 6555, p. 371-374.

Nelson, A.R., Kelsey, H.M., and Witter, R.C., 2006, Great earthquakes of variable magnitude at the Cascadia subduction zone: Quaternary Research, v. 65, no. 3, p. 354-365, doi:10.1016/j.yqres.2006.02.009.

Nittrouer, C.A., Sternberg, R.W., Carpenter, R., and Bennett, J.T., 1979, The use of Pb-210 geochronology as a sedimentological tool-Application to the Washington continental shelf: Marine Geology, v. 31, no. 3-4, p. 297-316, doi:10.1016/0025-3227(79)90039-2.

Nittrouer, C.A., and Sternberg, R.W., 1981, The formation of sedimentary strata in an allochthonous shelf environment; the Washington continental shelf: Marine Geology, v. 42, no. 1-4, p. 201-232.

Noda, A., 2008, Paleoseismicity along the southern Kuril Trench deduced from submarine-fan turbidites: Amsterdam, Netherlands, Elsevier, 73 p. 
Normark, W.R., and Reid, J.A., 2003, Extensive deposits on the Pacific Plate from late Pleistocene North American glacial lake outbursts: Journal of Geology, v. 111, no. 6; 6, p. 617-637.

North American Commission on Stratigraphic Nomenclature, 2005, North American Stratigraphic Code: American Association of Petroleum Geologists Bulletin, v. 89, no. 11, p. 1547-1591, doi:10.1306/07050504129.

O'Connor, J.E., 2004, The evolving landscape of the Columbia River Gorge: Lewis and Clark and cataclysms on the Columbia: Oregon Historical Quarterly, v. 105, no. 3, p. 390-421.

Parker, G., 1982, Conditions for the ignition of catastrophically erosive turbidity currents: Marine Geology, v. 46, no. 3-4, p. 307-327, doi:10.1016/0025-3227(82)90086-X.

Parker, G., Fukushima, Y., and Pantin, H.M., 1986, Self-accelerating turbidity currents: Journal of Fluid Mechanics, v. 171, p. 145-181, doi:10.1017/S0022112086001404.

Patton, J.R., Goldfinger, C., Morey, A.E., Erhardt, M., Black, B., Garrett, A.M., Djadjadihardja, Y., and Hanifa, U., 2010, Temporal clustering and recurrence of Holocene paleoearthquakes in the region of the 2004 Sumatra-Andaman earthquake [abs]: Seismological Research Letters, v. 81, no. 2, p. 290.

Paull, C.K., Mitts, P., Ussler, W., Keaten, R., and Greene, H.G., 2005, Trail of sand in upper Monterey Canyon, offshore California: Geological Society of America Bulletin, v. 117, no. 9-10, p. 1134-1145.

Petersen, M.D., Frankel, A.D., Harmsen, S.C., Mueller, C.S., Haller, K.M., Wheeler, R.L., Wesson, R.L., Zeng, Y., Boyd, O.S., Perkins, D.M., and Luco, N., 2008, Documentation for the 2008 update of the United States national seismic hazard mapsU.S. Geological Survey Open-File Report 2008-1128, 60 p., accessed February 25, 2012, at http://pubs.usgs.gov/of/2008/1128/.

Peterson, C.D., Carver, G.A., Cruikshank, K.M., Abramson, H.F., Garrison-Laney, C.E., and Dengler, L.A., 2011, Evaluation of the use of paleotsunami deposits to reconstruct inundation distance and runup heights associated with prehistoric inundation events, Crescent City, southern Cascadia margin: Earth Surface Processes and Landforms, v. 36, no. 7, p. 967-980, doi:10.1002/esp.2126.

Piper, D.J., and Normark, W.R., 1983, Turbidite depositional patterns and flow characteristics, Navy Submarine Fan, California Borderland: Sedimentology, v. 30, no. 5, p. 681-694.

Piper, D.J.W., and Savoye, B., 1993, Processes of late Quaternary turbidity current flow and deposition on the Var deep-sea fan, north-west Mediterranean Sea: Sedimentology, v. 40, no. 3, p. 557-582, doi:10.1111/j.1365-3091.1993.tb01350.x.

Piper, D.J.W., Cochonat, P., and Morrison, M.L., 1999, The sequence of events around the epicentre of the 1929 Grand Banks earthquake-Initiation of debris flows and turbidity current inferred from sidescan sonar: Sedimentology, v. 46, no. 1, p. 79-97, doi:10.1046/j.1365-3091.1999.00204.x.

Piper, D.J.W., and Normark, W.R., 2009, Processes that initiate turbidity currents and their influence on turbidites - A marine geology perspective: Journal of Sedimentary Research, v. 79, no. 5/6, p. 347-362.

Priest, G.R., Goldfinger, C., Wang, K., Witter, R.C., Zhang, Y., and Baptista, A.M., 2010, Confidence levels for tsunami-inundation limits in northern Oregon inferred from a 10,000-year history of great earthquakes at the Cascadia subduction zone: Natural Hazards, v. 54, p. 27-73. 
Puig, P., Ogston, A.S., Mullenbach, B.L., Nittrouer, C.A., Parsons, J.D., and Sternberg, R.W., 2004, Storm-induced sediment gravity flows at the head of the Eel submarine canyon, northern California margin: Journal of Geophysical Research, v. 109, no. C3, p. C03019, doi:10.1029/2003JC001918.

Ratzov, G., Collot, J., Sosson, M., and Migeon, S., 2010, Mass-transport deposits in the northern Ecuador subduction trench; result of frontal erosion over multiple seismic cycles: Earth and Planetary Science Letters, v. 296, no. 1-2, p. 89-102, doi:10.1016/j.epsl.2010.04.048.

Reilinger, R., and Adams, J., 1982, Geodetic evidence for active landward tilting of the Oregon and Washington coastal ranges: Geophysical Research Letters, v. 9, no. 4, p. 401-403.

Reimer, P.J., Baillie, M.G.L., Bard, E., Bayliss, A., Beck, J.W., Blackwell, P.G., Ramsey, C.B., Buck, C.E., Burr, G.S., Edwards, R.L., Friedrich, M., Grootes, P.M., Guilderson, T.P., Hajdas, I., Heaton, T.J., Hogg, A.G., Hughen, K.A., Kaiser, K.F., Kromer, B., McCormac, F.G., Manning, S.W., Reimer, R.W., Richards, D.A., Southon, J.R., Talamo, S., Turney, C.S.M., van der Plicht, J., and Weyhenmeye, C.E., 2009, IntCal09 and Marine09 radiocarbon age calibration curves, 0-50,000 years cal BP: Radiocarbon, v. 51, no. 4, p. 1111-1150.

Ricci-Lucchi, F., 2003, Turbidites and foreland basins: an Apenninic perspective: Marine and Petroleum Geology, v. 20, no. 6-8, p. 727-732, doi:10.1016/j.marpetgeo.2003.02.003.

Rogers, G.C., 1988, An assessment of the megathrust earthquake potential of the Cascadia subduction zone: Canadian Journal of Earth Sciences, v. 25, no. 6, p. 844-852, doi:10.1139/e88-083.

Ruiz, S., Kausel, E., Campos, J., Saragoni, G.R., and Madariaga, R., 2011, Identification of high frequency pulses from earthquake asperities along Chilean subduction zone using strong motion: Pure and Applied Geophysics, v. 168, no. 1-2, p. 125-139.

Saragoni, G.R., Lew, M., Naeim, F., Carpenter, L.D., Youssef, N.F., Rojas, F., and Adaros, M.S., 2010, Accelerographic measurements of the 27 February 2010 offshore Maule, Chile earthquake: The Structural Design of Tall and Special Buildings, v. 19, no. 8, p. 866-875, doi:10.1002/tal.673.

Satake, K., Shimazaki, K., Tsuji, Y., and Ueda, K., 1996, Time and size of a giant earthquake in Cascadia inferred from Japanese tsunami records of January 1700: Nature, v. 379, no. 6562, p. 246-249.

Satake, K., Wang, K., and Atwater, B.F., 2003, Fault slip and seismic moment of the 1700 Cascadia earthquake inferred from Japanese tsunami descriptions: Journal of Geophysical Research, v. 108, no. B11, p. 17, doi:10.1029/2003JB002521.

Savage, J.C., Lisowski, M., and Prescott, W., 1981, Geodetic strain measurements in Washington: Journal of Geophysical Research, v. 86, no. B6, p. 4929-4940.

Shanmugam, G., 2009, Comment on "Late Holocene Rupture of the Northern San Andreas Fault and Possible Stress Linkage to the Cascadia Subduction Zone" by Chris Goldfinger, Kelly Grijalva, Roland Burgmann, Ann E. Morey, Joel E. Johnson, C. Hans Nelson, Julia Gutierrez-Pastor, Andrew Ericsson, Eugene Karabanov, Jason D. Chaytor, Jason Patton, and Eulalia Gracia: Bulletin of the Seismological Society of America, v. 99, no. 4, p. 2594-2598, doi:10.1785/0120080030. 
Shennan, I., Long, A.J., Rutherford, M.M., Green, F.M., Innes, J.B., Lloyd, J.M., Zong, Y., and Walker, K.J., 1996, Tidal marsh stratigraphy, sea-level change and large earthquakes; 1, A 5000 year record in Washington, U.S.A: Quaternary Science Reviews, v. 15, no. 10, p. 1023-1059.

Stein, S., Engeln, J.F., Demets, C., Gordon, R.G., Woods, D., Lundgren, P., Argus, D., Stein, C., and Wiens, D.A., 1986, The Nazca-South America convergence rate and the recurrence of the great 1960 Chilean earthquake: Geophysical Research Letters, v. 13, no. 8, p. 713716, doi:10.1029/GL013i008p00713.

Sternberg, R.W., 1986, Transport and accumulation of river-derived sediment on the Washington continental shelf, USA: Journal of the Geological Society, v. 143, no. 6, p. 945-956, doi:10.1144/gsjgs.143.6.0945.

Stokke, P.R., Carson, B., and Baker, E.T., 1977, Comparison of bottom nepheloid layer and late Holocene deposition on Nitinat Fan-Implications for lutite dispersal and deposition: Geological Society of America Bulletin, v. 88, no. 11, p. 1586-1592.

Sumner, E.J., Amy, L.A., and Talling, P.J., 2008, Deposit structure and processes of sand deposition from decelerating sediment suspensions: Journal of Sedimentary Research, v. 78, no. 8, p. 529-547, doi:10.2110/jsr.2008.062.

Sumner, E.[J.], Siti, M., McNeill, L.C., Talling, P.J., Wynn, R., Henstock, T., Djajadihardja, Y., and Permana, H., 2010, Testing the validity of using turbidites as an earthquake proxy on the Sumatran margin [abs]: Eos (Transactions, American Geophysical Union), Abstract T11D-2129 presented at 2010 Fall Meeting, American Geophysical Union, San Francisco, Calif., 13-17 Dec.

Suzuki, W., Aoi, S., Sekiguchi, H., and Kunugi, T., 2011, Rupture process of the 2011 TohokuOki mega-thrust earthquake (M9.0) inverted from strong-motion data: Geophysical Research Letters, v. 38, p. L00G16, doi:10.1029/2011GL049136.

Takada, K., and Atwater, B.F., 2004, Evidence for liquefaction identified in peeled slices of Holocene deposits along the lower Columbia River, Washington: Bulletin of the Seismological Society of America, v. 94, no. 2, p. 550-575.

Thompson, J., 2011, Cascadia's fault - The coming earthquake and tsunami that could devastate North America: Berkeley, Calif., Counterpoint; Publishers Group West, 352 p.

Traykovski, P., Geyer, W.R., Irish, J.D., and Lynch, J.F., 2000, The role of wave-induced density-driven fluid mud flows for cross-shelf transport on the Eel River continental shelf: Continental Shelf Research, v. 20, no. 16, p. 2113-2140, doi:10.1016/S02784343(00)00071-6.

Turner, T., Ward, J., James, P., and Reiter, M., 2007, Utilization of lidar-derived topographic data for landform mapping and slope stability analysis [abs]: Geological Society of America, Abstracts with Programs, v. 39, no. 4, p. 32.

Usami, T., 1996, Shinpen Nihon higai jishin souran, zouho kaitei-ban 416-1995 [Materials for comprehensive list of destructive earthquakes in Japan, 416-1995, revised and enlarged edition]: Tokyo, Tokyo Daigaku Shuppankai [University of Tokyo Press], 493 p.

Williams, H.F.L., Hutchinson, I., and Nelson, A.R., 2005, Multiple sources for late-Holocene tsunamis at Discovery Bay, Washington State, USA: The Holocene, v. 15, no. 1, p. 6073, doi:10.1191/0956683605hl784rp.

Williams, M.C., Tréhu, A.M., and Braunmiller, J., 2011, Seismicity at the Cascadia plate Boundary beneath the Oregon continental shelf: Bulletin of the Seismological Society of America, v. 101, no. 3, p. 940-950, doi:10.1785/0120100198. 
Witter, R.C., Zhang, Y., Wang, K., Priest, G.R., Goldfinger, C., Stimely, L.L., English, J.T., and Ferro, P.A., 2011, Simulating tsunami inundation at Bandon, Coos County, Oregon, using hypothetical Cascadia and Alaska earthquake scenarios: Oregon Department of Geology and Mineral Industries, Special Report 43 [DVD].

Yamaguchi, D.K., Atwater, B.F., Bunker, D.E., Benson, B.E., and Reid, M.S., 1997, Tree-ring dating the 1700 Cascadia earthquake: Nature, v. 389, no. 6654, p. 922-923.

Yamazaki, Y., Lay, T., Cheung, K.F., Yue, H., and Kanamori, H., 2011, Modeling near-field tsunami observations to improve finite-fault slip models for the 11 March 2011 Tohoku earthquake: Geophysical Research Letters, v. 38, p. L00G15, doi:10.1029/2011GL049130.

Yue, H., and Lay, T., 2011, Inversion of high-rate (1 sps) GPS data for rupture process of the 11 March 2011 Tohoku earthquake (Mw 9.1): Geophysical Research Letters, v. 38, p. L00G09, doi:10.1029/2011GL048700.

Zdanowicz, C.M., and Zielinski, G.A., 1999, Mount Mazama eruption: calendrical age verified and atmospheric impact assessed: Geology, v. 27, no. 7, p. 621-624, doi:10.1130/00917613(1999)027<0621:MMECAV>2.3.CO;2. 


\section{Tables}

Table 1. Examples of deep-sea turbidites that have been correlated with earthquakes outside of Cascadia.

\begin{tabular}{|c|c|c|c|}
\hline Setting & $\begin{array}{c}\text { Age } \\
\text { range }\end{array}$ & $\begin{array}{l}\text { Primary } \\
\text { reference }\end{array}$ & Notes \\
\hline $\begin{array}{l}\text { Broad basin as } \\
\text { deep as } 1,750 \mathrm{~m} \\
\text { that slopes } \\
\text { upward to the } \\
\text { vicinity of Port } \\
\text { au Prince, Haiti }\end{array}$ & $\begin{array}{l}\text { A.D. } \\
2010\end{array}$ & $\begin{array}{l}\text { McHugh } \\
\text { and others } \\
\text { (2011) }\end{array}$ & $\begin{array}{l}\text { A turbidite was sampled } 2 \text { months after the earthquake of January } 12 \text {, } \\
\text { 2010. It was linked to earthquake by association with coastal landslides } \\
\text { and lateral spreading and by dating with a short-lived thorium isotope. } \\
\text { The turbidite provides a basis for interpreting underlying turbidites as } \\
\text { evidence for earthquakes that may be difficult to identify onshore. }\end{array}$ \\
\hline $\begin{array}{l}\text { Continental- } \\
\text { slope basins and } \\
\text { trench offshore } \\
\text { northern } \\
\text { Sumatra, } \\
\text { Indonesia }\end{array}$ & $\begin{array}{l}\text { past } \\
7,500 \\
\mathrm{yr}\end{array}$ & $\begin{array}{l}\text { Meeting } \\
\text { abstracts } \\
\text { of Patton } \\
\text { and others } \\
(2010) \\
\text { and } \\
\text { Sumner } \\
\text { and others } \\
(2010)\end{array}$ & $\begin{array}{l}\text { Assessments differ. Patton and others (2010) reported turbidite evidence } \\
\text { for a } 7,500 \text {-year history of recurrent earthquakes at intervals averaging } \\
400 \text { years. By contrast, Sumner and others }(2010) \text { concluded that } \\
\text { "turbidites do not provide a simple and reliable record of large } \\
\text { earthquakes on the Sumatran margin." They cited an absence of slope- } \\
\text { basin turbidites related to the } 2004 \text { and } 2005 \text { earthquakes, difficulties with } \\
\text { stratigraphic correlation between slope and trench, and basin-to-basin } \\
\text { differences in counts of turbidites above what may be the same volcanic- } \\
\text { ash layer. }\end{array}$ \\
\hline $\begin{array}{l}\text { Abyssal basin } \\
\text { offshore Iran } \\
\text { and Pakistan }\end{array}$ & $\begin{array}{l}\text { past } \\
25,000 \\
\mathrm{yr}\end{array}$ & $\begin{array}{l}\text { Bourget } \\
\text { and others } \\
(2010)\end{array}$ & $\begin{array}{l}\text { Late Holocene turbidites were correlated among cores as much as } 200 \mathrm{~km} \\
\text { apart on the basis of grain size, thickness, and a few limiting radiocarbon } \\
\text { ages. These turbidites were ascribed to sediment gravity flows triggered } \\
\text { either by Makran Subduction Zone earthquakes or by resuspension during } \\
\text { monsoon storms. }\end{array}$ \\
\hline $\begin{array}{l}\text { Abyssal basins } \\
\text { offshore } \\
\text { Portugal and } \\
\text { Spain }\end{array}$ & $\begin{array}{l}\text { past } \\
16,000 \\
\mathrm{yr}\end{array}$ & $\begin{array}{l}\text { Gràcia } \\
\text { and others } \\
(2010)\end{array}$ & $\begin{array}{l}\text { Turbidites were interpreted as evidence for seven great earthquakes of } \\
\text { Holocene age. These include the documented earthquakes of } 1755 \\
\text { (correlation by means of two limiting-maximum }{ }^{14} \mathrm{C} \text { ages on foraminfera) } \\
\text { and } 1969 \text { (dating by }{ }^{137} \mathrm{Cs} \text { ). }\end{array}$ \\
\hline $\begin{array}{l}\text { Trench offshore } \\
\text { Ecuador }\end{array}$ & $\begin{array}{l}\text { past } \\
15,000 \\
\mathrm{yr}\end{array}$ & $\begin{array}{l}\text { Ratzov } \\
\text { and others } \\
(2010)\end{array}$ & $\begin{array}{l}\text { Intervals between turbidites were estimated as } 17 \text { to } 371 \text { years, with an } \\
\text { average of } 189 \text { years, on the basis of average sedimentation rates in a core } \\
\text { that spans the past } 5,000 \text { years. Storms were discounted as triggers on the } \\
\text { basis of water depth at the shelf edge. Earthquakes were judged more } \\
\text { probable as triggers in view of a history that includes the great Colombia- } \\
\text { Ecuador earthquake of } 1906 \text { and a lesser shock in } 1942 \text {. }\end{array}$ \\
\hline $\begin{array}{l}\text { Kuril Trench } \\
\text { offshore eastern } \\
\text { Hokkaido, } \\
\text { Japan }\end{array}$ & $\begin{array}{l}\text { past } \\
10,000 \\
\mathrm{yr}\end{array}$ & $\begin{array}{l}\text { Noda and } \\
\text { others } \\
(2008)\end{array}$ & $\begin{array}{l}\text { Calibration with historical and onshore geological records gave mixed } \\
\text { results. The turbidites found above } 17 \text { th-century volcanic-ash layers may } \\
\text { correspond with just half the nearby historical great earthquakes. No } \\
\text { widespread turbidite was found that could correlate with an outsize } 17 \text { th- } \\
\text { century earthquake and tsunami that has been inferred from coastal } \\
\text { geology of eastern Hokkaido. }\end{array}$ \\
\hline $\begin{array}{l}\text { Submarine } \\
\text { channels that } \\
\text { head offshore } \\
\text { northern }\end{array}$ & $\begin{array}{l}\text { past } \\
15,000 \\
\mathrm{yr}\end{array}$ & $\begin{array}{l}\text { Goldfinge } \\
\mathrm{r} \text { and } \\
\text { others } \\
(2007)\end{array}$ & $\begin{array}{l}\text { At least eight turbidites less than } 3,000 \text { years old were correlated along } \\
300 \mathrm{~km} \text { of the northern San Andreas Fault by methods like those of } \\
\text { Goldfinger and others (in press). The most recent of these turbidites was } \\
\text { correlated with the } 1906 \text { San Francisco earthquake. }\end{array}$ \\
\hline
\end{tabular}

California 
Table 1. Examples of deep-sea turbidites that have been correlated with earthquakes outside of Cascadia.-Continued

\begin{tabular}{|c|c|c|c|}
\hline Setting & $\begin{array}{c}\text { Age } \\
\text { range }\end{array}$ & $\begin{array}{c}\text { Primary } \\
\text { reference }\end{array}$ & Notes \\
\hline $\begin{array}{l}\text { Basins along } \\
\text { the North } \\
\text { Antaolian Fault } \\
\text { at water depths } \\
\text { of about } 1,000 \\
\text { m beneath the } \\
\text { Sea of } \\
\text { Marmara, } \\
\text { Turkey }\end{array}$ & $\begin{array}{l}\text { past } \\
2,000 \\
\text { yr }\end{array}$ & $\begin{array}{l}\text { McHugh } \\
\text { and others } \\
(2006)\end{array}$ & $\begin{array}{l}\text { Eight historical earthquakes between A.D. } 181 \text { and } 1912 \text { were correlated } \\
\text { with fining-upward beds each having "a sharp basal erosional contact" } \\
\text { overlain by "multiple millimeter to centimeter thick laminae of fine- } \\
\text { grained sand and coarse silt that grade into a thick wedge of homogenous } \\
\text { medium- to fine-grained silt." (McHugh and others, 2006, p. 667). The } \\
\text { linkage to six of these was inferred from limiting-maximum radiocarbon } \\
\text { ages that have } 95 \text {-percent confidence intervals spanning two centuries or } \\
\text { more and which were not adjusted for differences between dated-material } \\
\text { age and turbidite age. Using longer cores, Beck and others (2007) inferred } \\
\text { that the earthquake signal in Holocene basin deposits of the Sea of } \\
\text { Marmara is dominated by evidence for seiching and dewatering. }\end{array}$ \\
\hline $\begin{array}{l}\text { Submarine fan } \\
\text { at } 3,000 \mathrm{~m} \\
\text { depth in Sea of } \\
\text { Japan offshore } \\
\text { northern } \\
\text { Honshu }\end{array}$ & $\begin{array}{l}\text { past } \\
1,000 \\
\mathrm{yr}\end{array}$ & $\begin{array}{l}\text { Nakajima } \\
\text { and Kanai } \\
(2000)\end{array}$ & $\begin{array}{l}\text { A core from the fan showed five turbidites above a volcanic-ash layer } \\
\text { from about } 1,000 \text { years ago. The youngest of these turbidites was } \\
\text { correlated with the } 1983 \text { Sea of Japan earthquake on basis of }{ }^{137} \mathrm{Cs} \text { and } \\
{ }^{210} \mathrm{~Pb} \text { dating. Basal sandy parts of each of two of the turbidites were found } \\
\text { to contain multiple layers that differ from one another in composition and } \\
\text { which were ascribed to multiple submarine slides from the same } \\
\text { earthquake (Nakajima and Kanai, 2000, p. 16). }\end{array}$ \\
\hline $\begin{array}{l}\text { Steep-walled } \\
\text { basins on the } \\
\text { floor of the } \\
\text { Ionian Sea } \\
\text { south of Italy }\end{array}$ & $\begin{array}{l}8,000- \\
14,000 \\
\text { years } \\
\text { ago }\end{array}$ & $\begin{array}{l}\text { Kastens } \\
\text { (1984) }\end{array}$ & $\begin{array}{l}\text { Four turbidites correlated between a volcanic ash layer and a sapropel } \\
\text { layer correlated between two basins within an area about } 5 \text { by } 5 \mathrm{~km} \text {. This } \\
\text { correlation was interpreted as evidence that earthquakes felt in both } \\
\text { basins generated basin-wall debris flows that transformed into turbidity } \\
\text { currents on the basin floors. }\end{array}$ \\
\hline $\begin{array}{l}\text { Continental } \\
\text { slope and } \\
\text { abyssal plain } \\
\text { offshore Grand } \\
\text { Banks, New } \\
\text { Foundland }\end{array}$ & $\begin{array}{l}\text { A.D. } \\
1929\end{array}$ & $\begin{array}{l}\text { Heezen } \\
\text { and } \\
\text { Ewing } \\
(1952)\end{array}$ & $\begin{array}{l}\text { Classic example of a turbidity current inferred from breakage of } \\
\text { submarine cables and interpreted as the downslope product of earthquake- } \\
\text { induced mass movements. Those mass movements, however, probably } \\
\text { went on for hours and ignited the turbidity current during that extended } \\
\text { time (Piper and others, 1999). }\end{array}$ \\
\hline
\end{tabular}


Table 2. Counts of turbidites that are known or inferred to postdate the eruption of Mount Mazama (Oregon) 7,800-7,500 sidereal years ago.

\begin{tabular}{|c|c|c|c|}
\hline Core ${ }^{1}$ & $\begin{array}{l}\text { Previous } \\
\text { counts }^{2}\end{array}$ & $\begin{array}{c}\text { Revised } \\
\text { count }\end{array}$ & Notes \\
\hline \multicolumn{4}{|r|}{ Juan de Fuca Channel (JdF) } \\
\hline $\begin{array}{l}\text { M9907- } \\
05\end{array}$ & $\begin{array}{c}13(\mathrm{G}, \text { by } \\
\text { correlation with } \\
\text { M9907-11 and - } \\
12)\end{array}$ & $\begin{array}{l}\text { Unknown; } \\
\text { perhaps between } \\
13 \text { and } 20\end{array}$ & $\begin{array}{l}\text { A sketch of trigger core M9907-05TC shows a total of } 7 \text { silty or sandy } \\
\text { beds high in turbidites T5, T6, T8, and T9 (Goldfinger and others, in } \\
\text { press, fig. 19), as denoted by ball-tipped lines in figure 5. Wiggle traces } \\
\text { match well with those of cores M9907-11 and -12, but highest four } \\
\text { turbidites are inferred missing from trigger core M9907-05TC. Mazama } \\
\text { ash not found. }\end{array}$ \\
\hline $\begin{array}{c}\text { M9907- } \\
12\end{array}$ & 13 or $14(\mathrm{G})$ & $13-15$ & $\begin{array}{l}\text { Turbidite T2 or T4 contains an extra silt bed (sketches of piston core } \\
\text { M9907-12PC differ), and an additional bed in T6 is tentatively called T5b } \\
\text { (Goldfinger and others, in press, figs. 19,20). }\end{array}$ \\
\hline 6705-2 & $\begin{array}{c}16(\mathrm{GK}) \\
16-19(\mathrm{~A})\end{array}$ & $\begin{array}{c}\text { Unknown, } \\
\text { mainly because } \\
\text { of uncertainty } \\
\text { about position of } \\
\text { lowest Mazama } \\
\text { ash }\end{array}$ & $\begin{array}{l}\text { Third turbidite from the top is doubled (fig. } 4 A \text { ). The core's only sandy } \\
\text { turbidites, no. } 11 \text { and } 12 \text {, could be lumped into one turbidite (if the } \\
\text { hemipelagic clay between them is a rip-up clast) or split further. Griggs } \\
\text { (1969, his fig. } 8 \text { ) plotted the Mazama below all turbidites in this core; } \\
\text { table } 3 \text { of Griggs and Kulm (1970b) mistakenly implies that he found it in } \\
\text { the lowest of these turbidites. John Adams (written commun., 2010) } \\
\text { found ash in smear slides of the next-to-lowest turbidite and none below } \\
\text { it. Adams (1990, p. } 573 \text { ) concluded that the lowest turbidite containing } \\
\text { the Mazama ash is probably the 16th but "might be as low as the 19th" } \\
\text { from the top. }\end{array}$ \\
\hline $6705-6$ & $14(\mathrm{GK}, \mathrm{A})$ & $\begin{array}{l}\text { Unknown } \\
\text { because of } \\
\text { Mazama } \\
\text { uncertainty and } \\
\text { turbidite } \\
\text { complexity }\end{array}$ & $\begin{array}{l}\text { Position of lowest Mazama ash known only from generalized plot of } \\
\text { Griggs (1969, his fig. } 8 \text { ) and is not marked on his core log. Two of the } \\
\text { approximately } 14 \text { turbidites above this level are complex (fig. } 4 A \text { ). These } \\
14 \text { exclude two thin silt beds in thick clay that may represent centuries or } \\
\text { even millennia without turbidite deposition. Counts further complicated } \\
\text { by probable backflooding by Quinault-Willapa flows (fig. } 4 E \text { ). }\end{array}$ \\
\hline \multicolumn{4}{|r|}{ Quinault and Willapa Channels (QW) } \\
\hline 53-18 & $14(\mathrm{~B}, \mathrm{~A})$ & $\begin{array}{l}14, \text { including } \\
\text { two mud } \\
\text { turbidites; site } \\
\text { above thalweg }\end{array}$ & $\begin{array}{l}\text { Includes two silt beds that Barnard (1973, p. 162) plotted in his core log. } \\
\text { Barnard (1978, p. 111) inferred that "at least" 14 post-Mazama turbidity } \\
\text { currents ran down Quinault Canyon-"at least" probably because site is } \\
\sim 5 \mathrm{~km} \text { north of Quinault Channel and }>10 \mathrm{~m} \text { above it, as judged from } \\
\text { maps and site depth reported in his dissertation (Barnard, 1973). }\end{array}$ \\
\hline $\begin{array}{c}\text { M9907- } \\
14\end{array}$ & $13 ?(\mathrm{G})$ & $11-12$ & $\begin{array}{l}\text { Turbidites thinner than those in nearby core } 6705-5 . \text { T3 queried and T7 } \\
\text { not evident in density or magnetic susceptibility log for trigger core 14TC } \\
\text { (Goldfinger and others, in press, Figs. 19, 20). }\end{array}$ \\
\hline $6705-5$ & $\begin{array}{l}15(\mathrm{GK}, \mathrm{A}) \\
15 \text { or } 13(\mathrm{G})\end{array}$ & $\begin{array}{l}\text { Probably }<13 \text { if } \\
\text { Holocene total is } \\
13\end{array}$ & $\begin{array}{l}\text { Griggs ( } 1969 \text {, his fig. 8) plotted Mazama ash below all } 15 \text { turbidites in } \\
\text { this core; table } 3 \text { of Griggs and Kulm (1970b, p. 1375) mistakenly implies } \\
\text { that he found it in the lowest of these turbidites. Goldfinger and others (in } \\
\text { press) report that core } 6705-5 \text { contains } 15 \text { or } 13 \text { post-Mazama turbidites } \\
\text { (respectively, in their figure } 51 \text { and in their text under the heading } \\
\text { "Willapa Channel Turbidite Sequence"). Griggs now interprets the lowest } \\
\text { two turbidites (numbers } 14 \text { and } 15 \text { ) as Pleistocene on the basis that they } \\
\text { are thicker, more abundantly bedded, and mostly coarser grained than the } \\
\text { turbidites above (fig. } 4 A \text { ) and on the further basis that number } 14 \text { and the } \\
\text { uppermost part of number } 15 \text { contain abundant planktonic foraminifera } \\
\text { noted on the core log. }\end{array}$ \\
\hline
\end{tabular}


Table 2. Counts of turbidites that are known or inferred to postdate the eruption of Mount Mazama (Oregon) 7,800-7,500 sidereal years ago. - Continued

\begin{tabular}{|c|c|c|c|}
\hline Core $^{1}$ & $\begin{array}{l}\text { Previous } \\
\text { counts }^{2}\end{array}$ & $\begin{array}{c}\text { Revised } \\
\text { count }\end{array}$ & Notes \\
\hline \multicolumn{4}{|r|}{ Cascadia Channel (C) } \\
\hline $\begin{array}{c}6508- \\
\text { K1 }\end{array}$ & $\begin{array}{c}13(\mathrm{GK}) \\
14(\mathrm{~A})\end{array}$ & $\geq 14$ & $\begin{array}{l}\text { Minimum turbidite count of } 14 \text { includes the turbidites labeled complex in } \\
\text { figure } 4 A, B \text {. Recurrence interval of Griggs and Kulm (1970b, p. 1375) } \\
\text { corresponds to a count of } 13 \text {. Adams (1990, p. } 573 \text { ) revised the count to } \\
14 \text { for consistency with ash contents noted on Griggs's log of the lowest } \\
\text { part of the } 14 \text { th turbidite from top: } 5 \text { percent in sand, and } 24 \text { percent in } \\
\text { coarse silt beneath it (fig. } 4 A, B \text { ). This data is not tabulated in his } \\
\text { dissertation (Griggs, } 1969 \text {, appendix III). An analysis listed there shows } 8 \\
\text { percent ash in the hemipelagic clay that separates turbidites } 13 \text { and } 14 \\
\text { (not shown in figure } 4 \text {, which plots ash data from the turbidites only). }\end{array}$ \\
\hline $6509-15$ & $13(\mathrm{GK}, \mathrm{A})$ & 13 & The turbidite count of 13 includes one complex turbidite (fig. $4 C$ ). \\
\hline
\end{tabular}

${ }^{1}$ Cores grouped by channel and listed there from upstream to downstream.

${ }^{2}$ A, Adams (1990); B, Barnard (1973; 1978); G, Goldfinger and others (in press); GK, Griggs and Kulm (1970b). 


\section{Figures}

[Note: These 8 figures, covering most of 10 pages in all, are best viewed with facing pages for figures 2 (left) and 3 (right), figure 4 (two pages), figure 5 (also two pages), and figures 6 (left) and 7 (right).] 
$A$ LONGITUDINAL PROFILES from coast to foot of continental slope and beyond

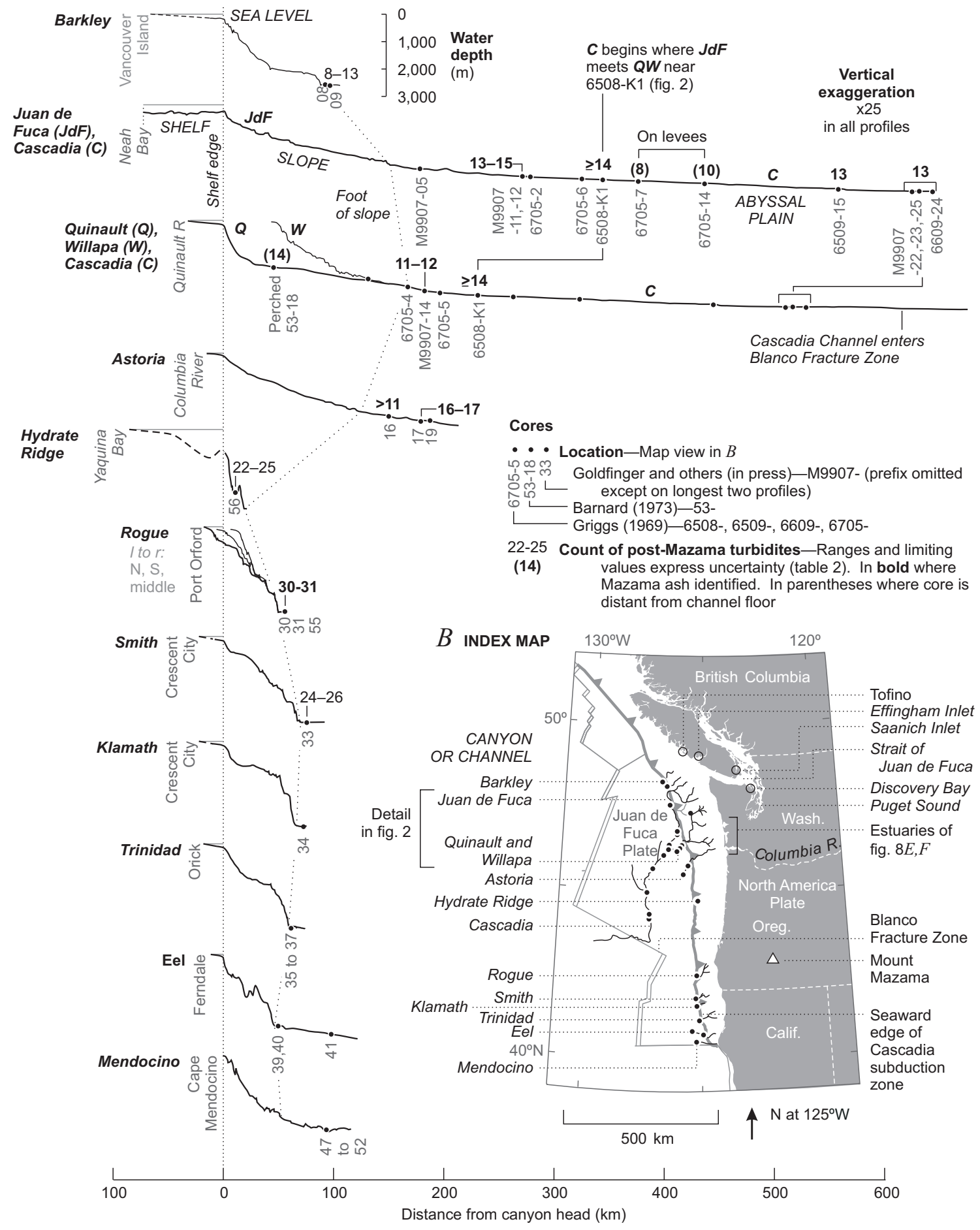

Figure 1. Bathymetric profiles and index map for Cascadia Subduction Zone. A, Longitudinal profiles of submarine canyons and channels, plotted at common scale to illustrate the physiographic settings of counts of postMazama turbidites-turbidites that were deposited after the catastrophic eruption of Mount Mazama (Crater Lake), Oregon, 7,800-7,500 sidereal years ago. Compiled from Goldfinger and others (in press, figs. 16, 18, 21, 23, 26, 29, 30, 36, 39), Griggs and Kulm (1970a), and bathymetric map of Barnard (Barnard, 1973, his fig. 6 , contour interval $100 \mathrm{~m}) . B$, Index map. 
$A$ ChANNel Network

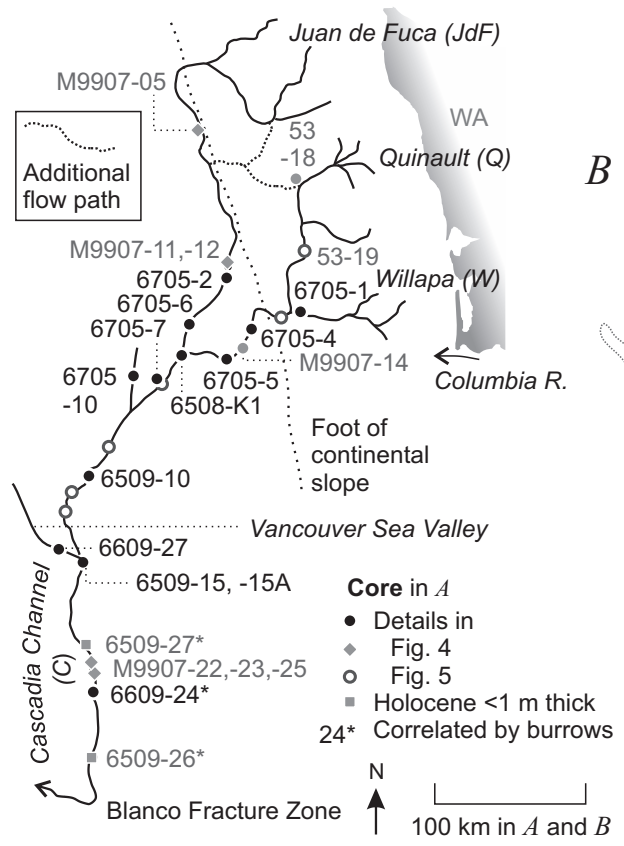

$C$ tRANSVERSE PROFiles

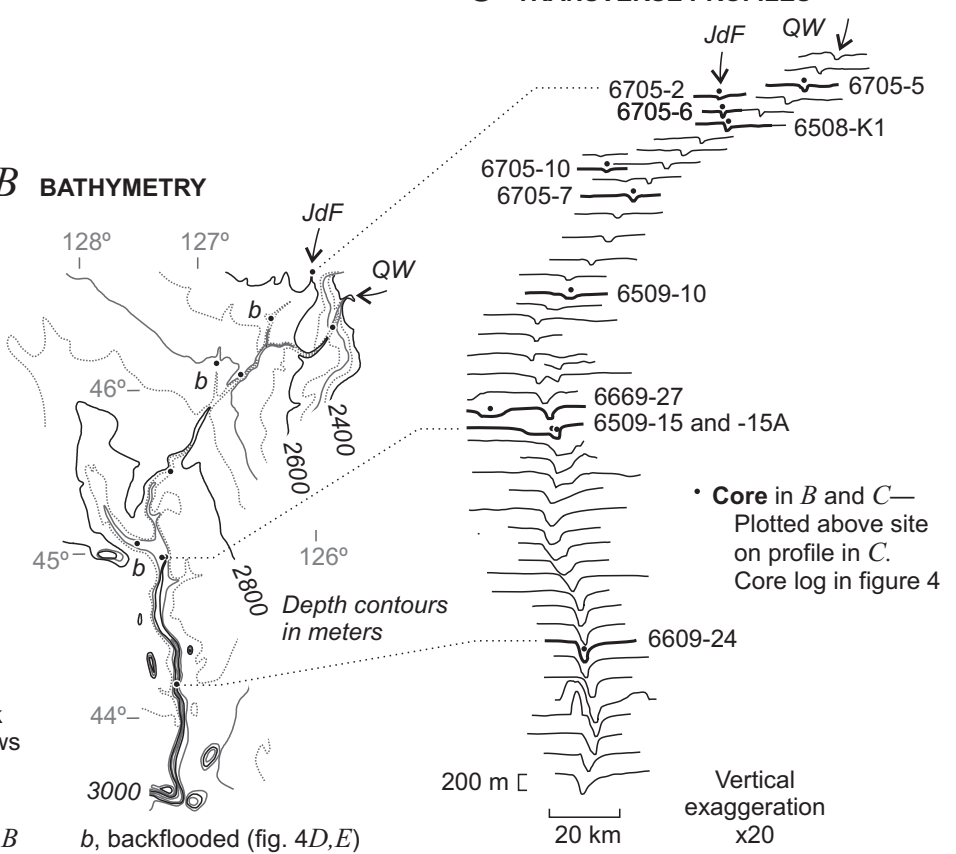

$D$ LONGITUDINAL PROFILES above and below junction that marks head of Cascadia Channel

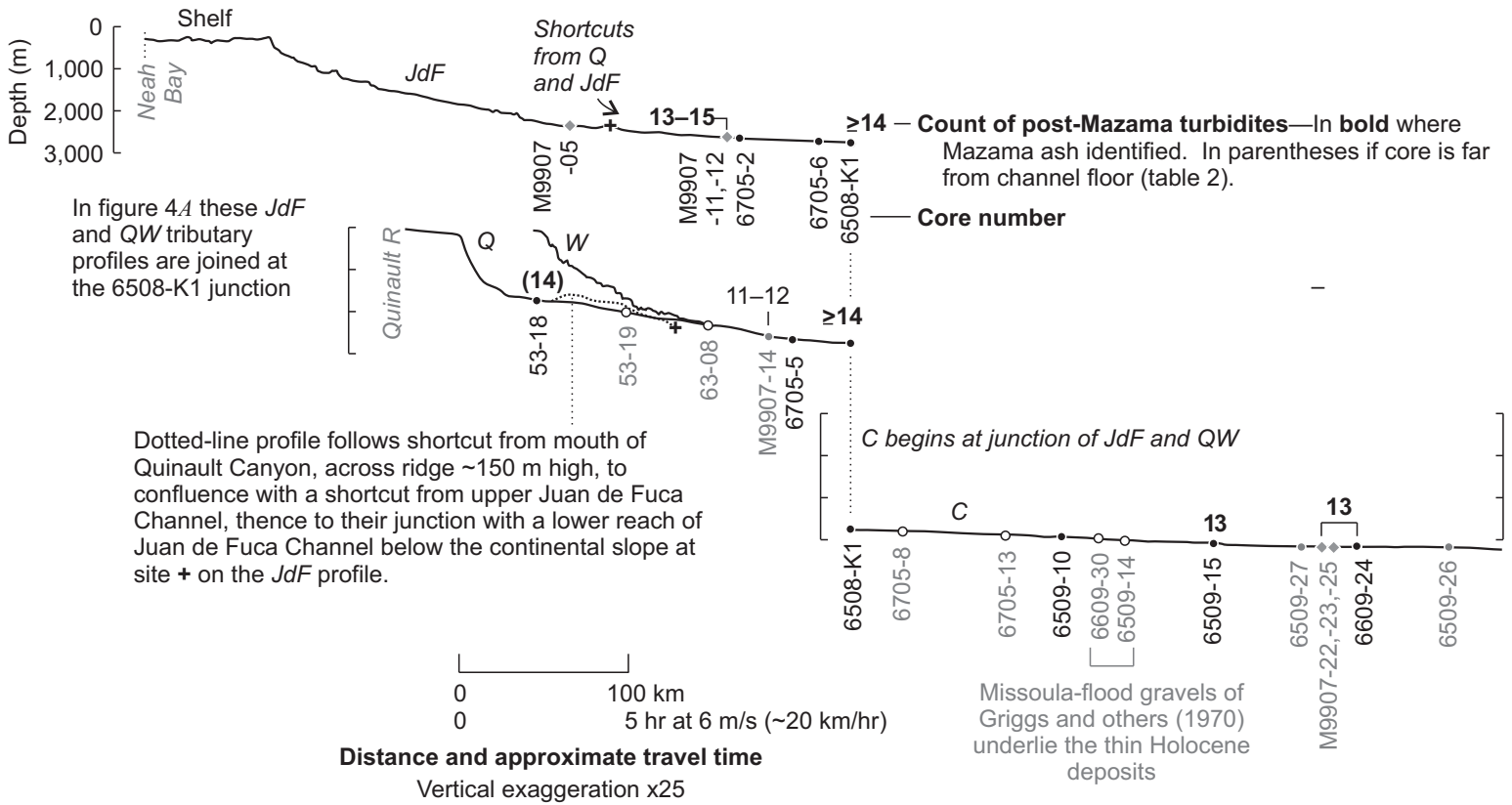

Figure 2. Locations of submarine canyons and channels, and of cores, in the network of Cascadia Channel. $A$, Cores from Griggs and Kulm (1970b), Barnard (1978), and Goldfinger and others (in press) plotted on skeletal view of late Holocene channel network from Goldfinger and others (in press, their fig. 2) and Barnard (1978, fig. 17). B, Bathymetry from Griggs and Kulm (1970b, p. 1364). C, Cross-channel profiles from Griggs and Kulm (1970a). D, Longitudinal profiles aligned at junction that marks head of Cascadia Channel. Compiled from Griggs and Kulm (1970a), Goldfinger and others (in press, figs. 18, 21, 23), and bathymetric map of Barnard (1973, his fig. 6). Turbidite counts from table 2 and figure 4, Griggs and Kulm (1970b, Table 3), and Goldfinger and others (in press, fig. 24). Speed of $6 \mathrm{~m} / \mathrm{s}$ from Griggs and Kulm (1970b, table 5). 


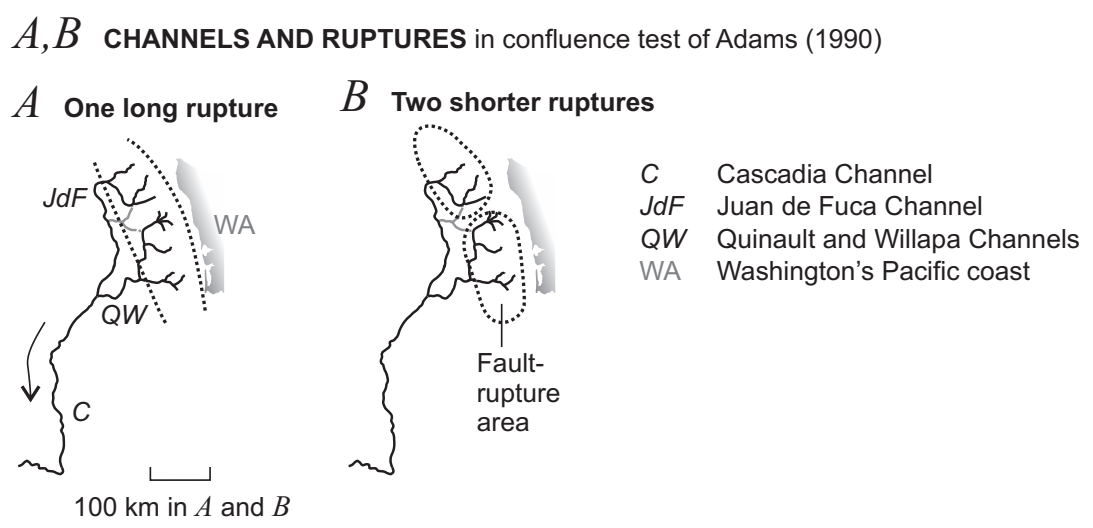

\section{$C-E$ OUTCOMES OF CONFLUENCE TEST}

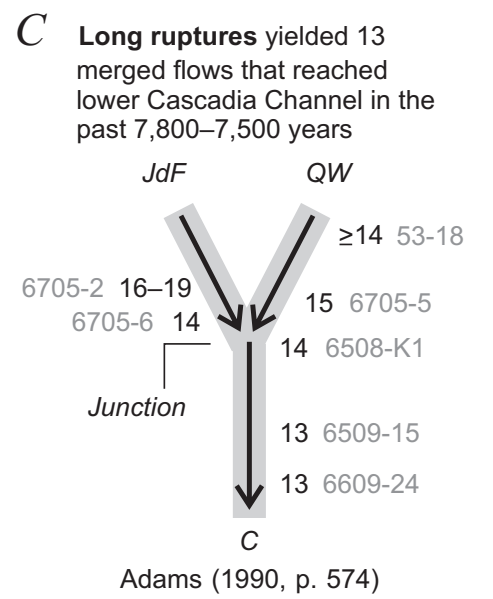

$D$ Long ruptures yielded 13 merged flows that reached lower Cascadia Channel in the past 7,800-7,500 years

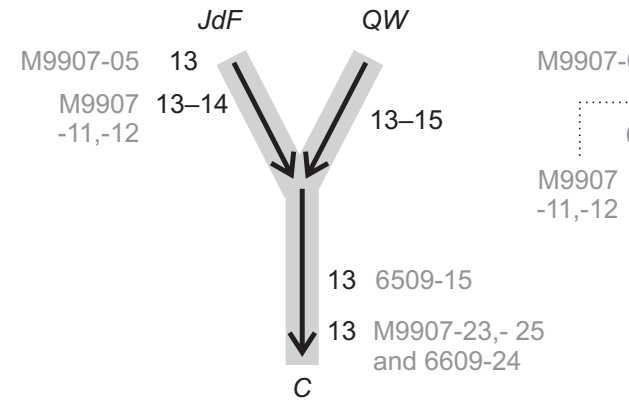

Goldfinger (2011, p. 46) and Goldfinger and others (in press, fig. 51)
$E$ Rupture length unclear from turbidite counts, mainly because flows in lower Cascadia Channel are probably derived from the $Q W$ tributary only

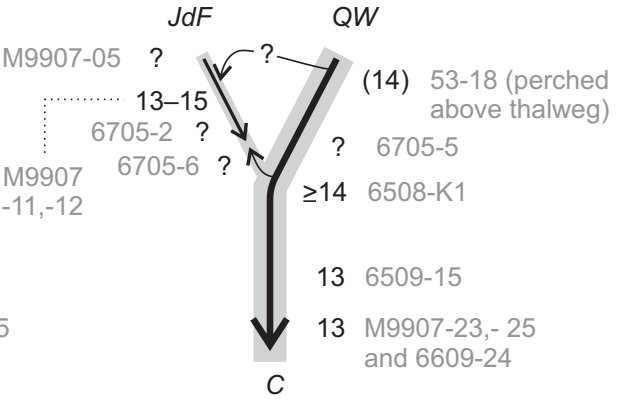

This report

(fig. 2, table 2)

14 Number of turbidites younger than Mazama ash (table 2)

M9907-23 Core number (location, figs. 1,2)

Figure 3. Skeletal views of the confluence test at Cascadia Channel and its tributaries. $A, B$, Deep-sea channels and hypothetical fault ruptures in confluence test of Adams (1990). C-E, Assumptions about relative sizes of flows (gray lines and black arrows) and counts of post-Mazama turbidites used in three versions of the confluence test. 


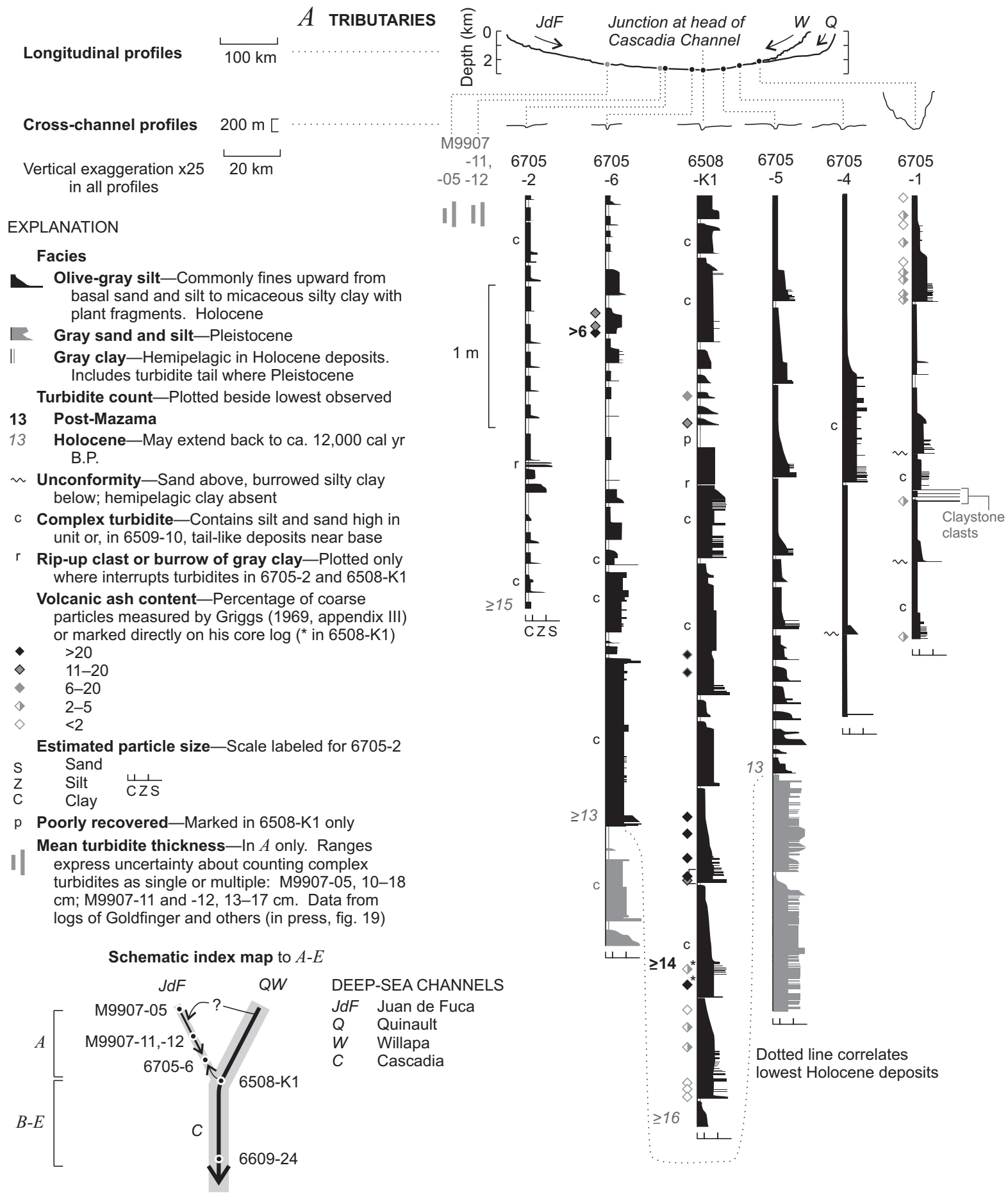

Figure 4. Previously unpublished details about cores collected in the late 1960s from Cascadia Channel and its tributaries. Bathymetric profiles from figure 2. Schematic particle-size trends traced from logs by G.B. Griggs in 1965-67; original scale, $10 \mathrm{~cm}$ in core $=3.3 \mathrm{~cm}$ on sketch. $A-D$, Cores from Juan de Fuca Channel and Quinault and Willapa Channels $(A)$, floor of Cascadia Channel $(B)$, wall and levee of Cascadia Channel $(C)$, and lowest reaches of three tributaries to Cascadia Channel $(D)$. [Figure and caption continued next page] 


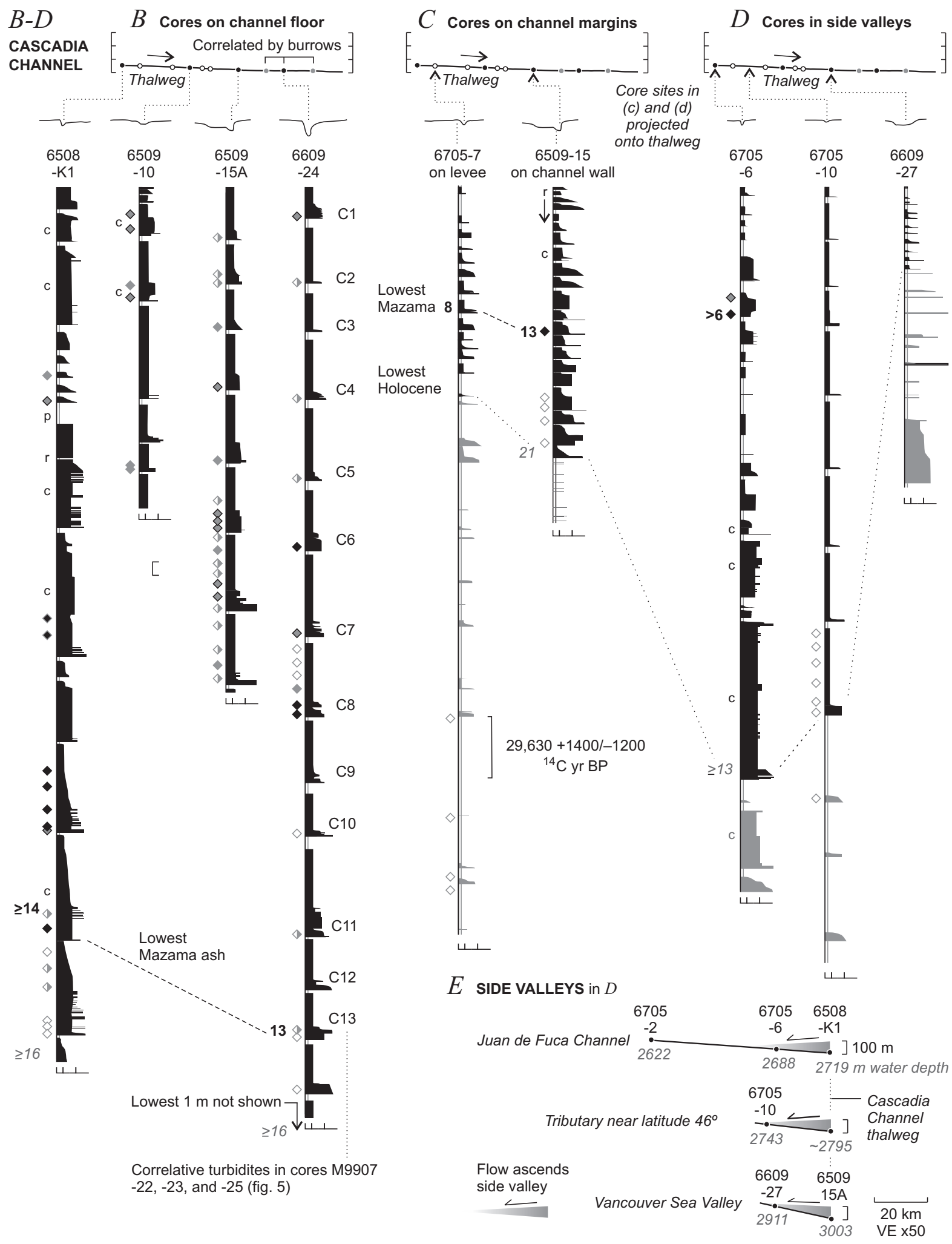

[Figure and caption continued from previous page] $E$, Setting of cores in $D$ plotted on bathymetric profiles of the lowest reaches of the side valleys. Gray shading schematically shows inferred backflooding up side-valley floor by flows that Griggs and Kulm (1970b, p. 1377) estimated as cresting more than $80 \mathrm{~m}$ above the Cascadia Channel thalweg. Water depths at core locations from Griggs (1969, p. 160). Figure formatted as pair of facing pages. 


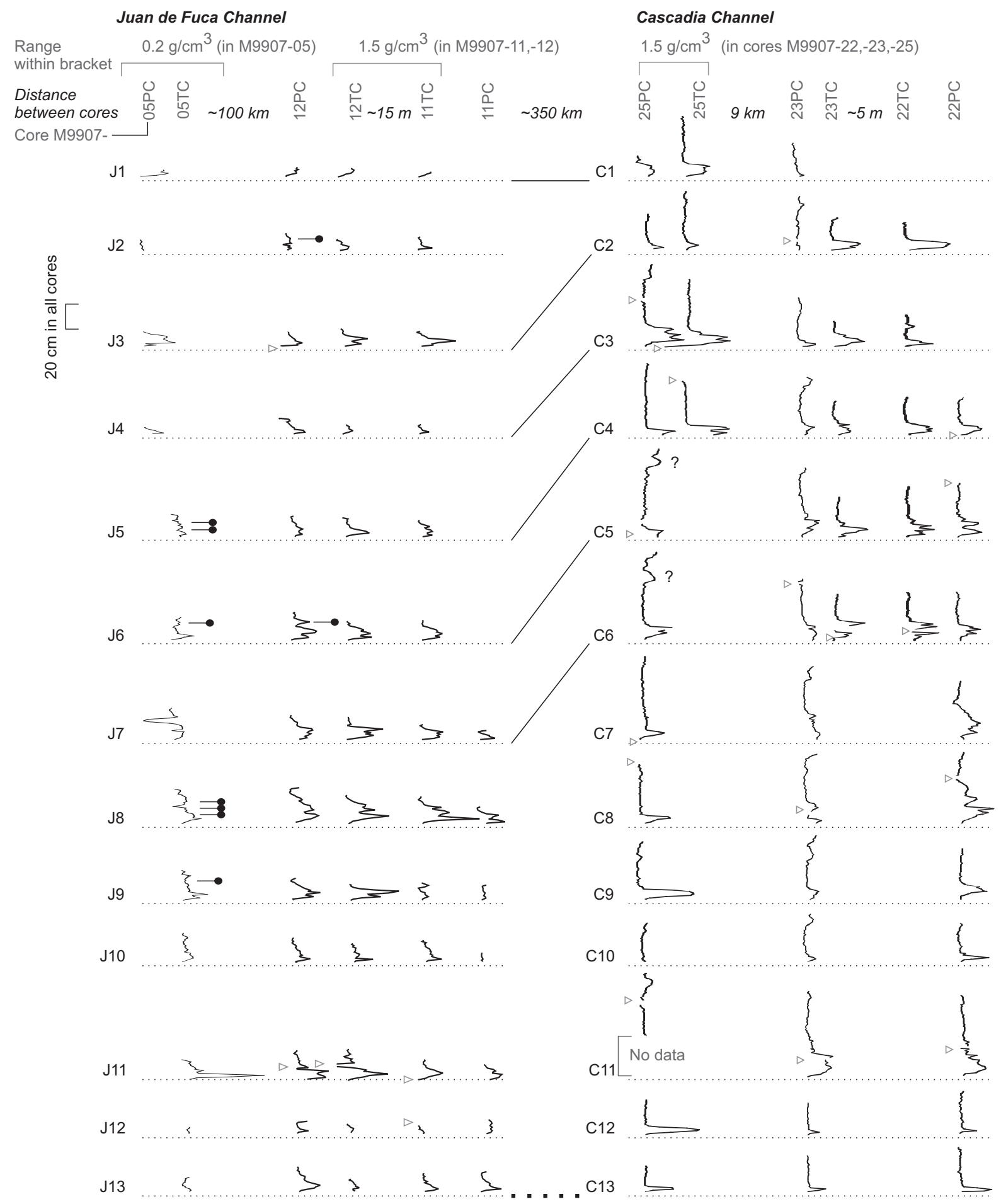

Figure 5. Geophysical logs used by Goldfinger and others (in press) in correlating turbidites between Juan de Fuca Channel and lower Cascadia Channel. Log segments are extracted from their figures 19 and 24, cut into pieces each of which includes a turbidite and its hemipelagic cap, and aligned by the correlation that Goldfinger and others (in press) inferred. [Figure and caption continued next page] 


\section{$B$ MAGNETIC SUSCEPTIBILITY}

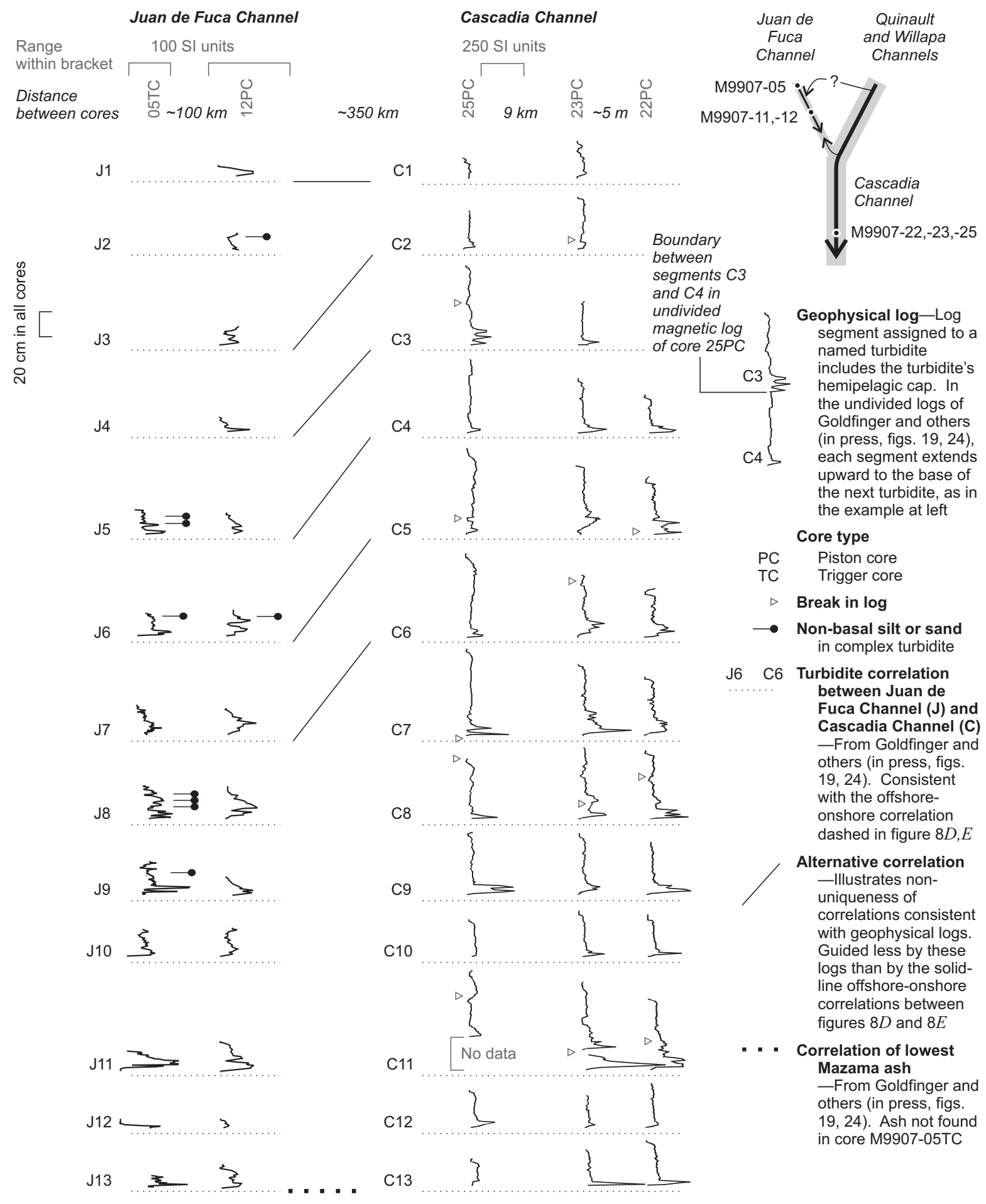

[Figure and caption continued from previous page] Local turbidite names, such as $\mathrm{J} 2$ and $\mathrm{C} 2$, are substituted for Goldfinger's regional names, such as T2. A, Density measured by attenuation of gamma rays. $B$, Magnetic subsceptibility. Figure formatted as pair of facing pages. 
$A$ STEPS in converting foraminiferal ages to turbidite ages

1. Correlate turbidites among nearby cores.

Sample hemipelagic clay for ${ }^{14} \mathrm{C}$ dating of planktonic foraminifera that predate the overlying turbidite.

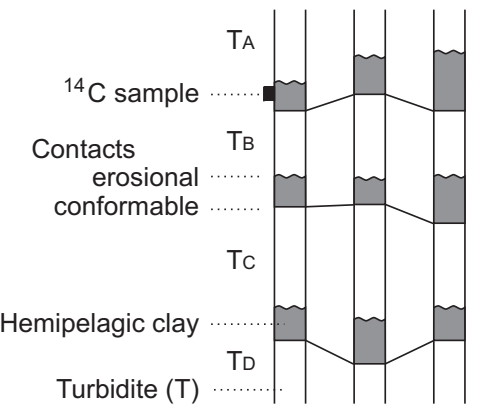

\section{Measure thickest hemipelagic clay} between two correlated turbidites $(h)$. Interpret it as approximating the interval's thickness before erosion. If the sampled clay is thinner, treat the difference as the amount eroded above that sample (e).

3. Relate thickness to time. Divide hemipelagic thickness $h$ by the age difference between bounding turbidites to obtain a sedimentation rate $(r)$ that includes effects of compaction:

$$
r=h /\left(\text { age } \mathrm{T}_{\mathrm{B}}-\text { age } \mathrm{TA}_{\mathrm{A}}\right)
$$

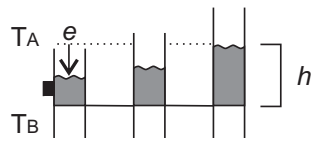

Examples of $e$ that shift turbidite ages by centuries (figs. $7 B, 8 D$ )

\begin{abstract}
4. Apply sedimentation rate to estimate the average time $(t)$ between deposition of the dated foraminifera and deposition of the overlying turbidite; correct for thicknesses of the sample $(s)$, the hemipelagic clay preserved above it $(p)$, and the clay inferred eroded $(e)$ :

$$
t=(e+p+(s / 2)) / r
$$
\end{abstract}
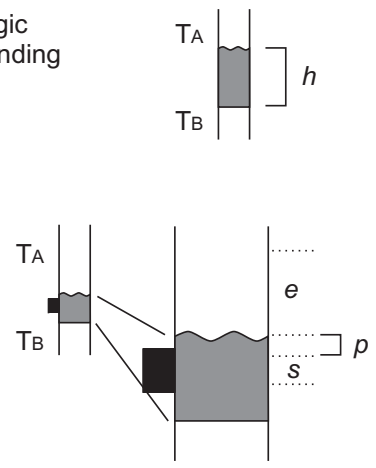

$\mathbf{0 . 5} \mathbf{c m}$ uncertainty in assumed by Goldfinger and others (in press) in erosion estimate $e$

$2 \mathbf{c m}$ in core sketches in $B$

100 yr of clay deposition at rate $r$ defined in step 3

$\mathrm{PC}$, piston core

$\mathrm{TC}$, trigger core

M9907-
$B$ VARIABLE EROSION ESTIMATES in nearby cores

Distances along Cascadia Channel

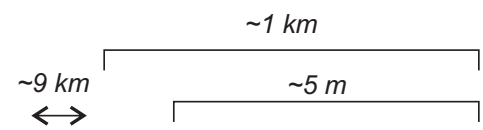

C4
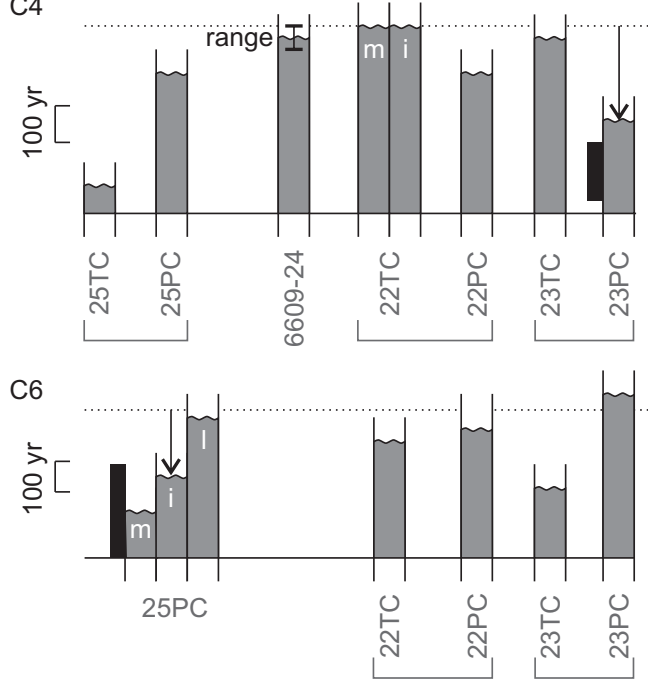

C8

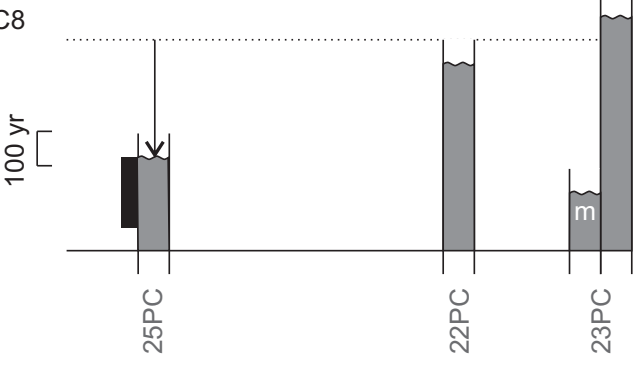

Parameters in $A$ in relation to core sketches in $B$

C8 $\cdots .$. Turbidite targeted for dating

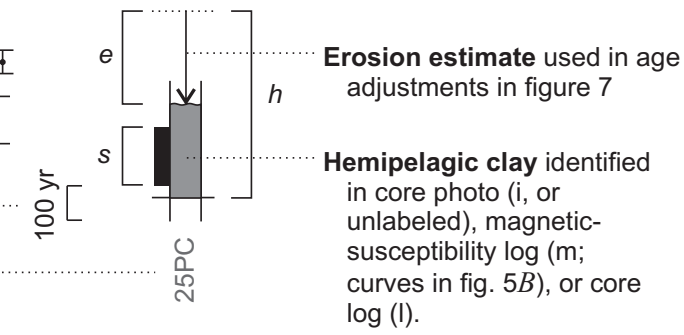

Figure 6. A, Steps used by Gutierrez-Pastor and others (2009) and Goldfinger and others (in press, appendix 1, "RC data" worksheet, columns AE-AG, and "Sed rate curve" worksheets) in adjusting radiocarbon ages to estimate times of deep-sea turbidite deposition along the Cascadia Subduction Zone. B, Examples of step 2 in which large amounts of erosion were estimated from highly variable thicknesses of correlated units of hemipelagic clay. 

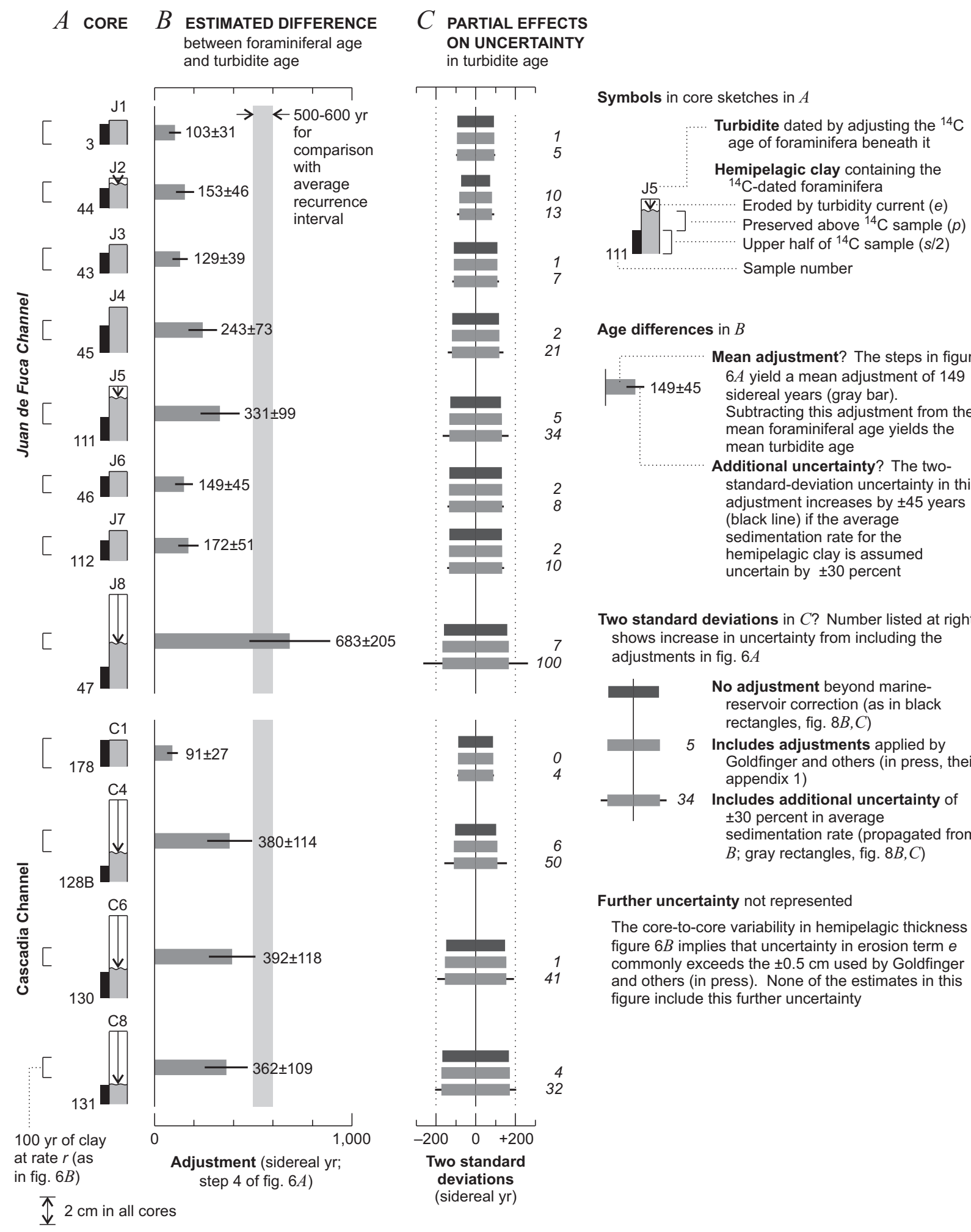

Age differences in $B$

Mean adjustment? The steps in figure $6 A$ yield a mean adjustment of 149 sidereal years (gray bar). Subtracting this adjustment from the mean foraminiferal age yields the mean turbidite age

Additional uncertainty? The twostandard-deviation uncertainty in this adjustment increases by \pm 45 years

(black line) if the average sedimentation rate for the hemipelagic clay is assumed uncertain by \pm 30 percent

Two standard deviations in $C$ ? Number listed at right shows increase in uncertainty from including the adjustments in fig. $6 \mathrm{~A}$

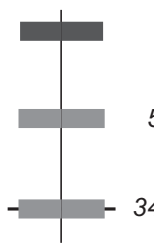

No adjustment beyond marinereservoir correction (as in black rectangles, fig. $8 B, C$ )

5 Includes adjustments applied by Goldfinger and others (in press, their appendix 1)

Includes additional uncertainty of \pm 30 percent in average sedimentation rate (propagated from $B$; gray rectangles, fig. $8 B, C$ )

Further uncertainty not represented

The core-to-core variability in hemipelagic thickness in figure $6 B$ implies that uncertainty in erosion term $e$ commonly exceeds the $\pm 0.5 \mathrm{~cm}$ used by Goldfinger and others (in press). None of the estimates in this figure include this further uncertainty

Figure 7. Uncertainties in adjustments to radiocarbon ages for turbidites in Cascadia Channel and Juan de Fuca Channel. Data from Goldfinger and others (in press, appendix 1, "RC data" worksheet, columns $\mathrm{F}, \mathrm{Q}, \mathrm{V}, \mathrm{W}, \mathrm{X}, \mathrm{Y}, \mathrm{AD}, \mathrm{AJ})$. $A$, Core sketches showing radiocarbon sample locations and hemipelagic thicknesses. $B$, Combined adjustment for mean estimate of hemipelagic thicknesses in $A$. $C$, Three estimates of uncertainty in turbidite age at two standard deviations.. 


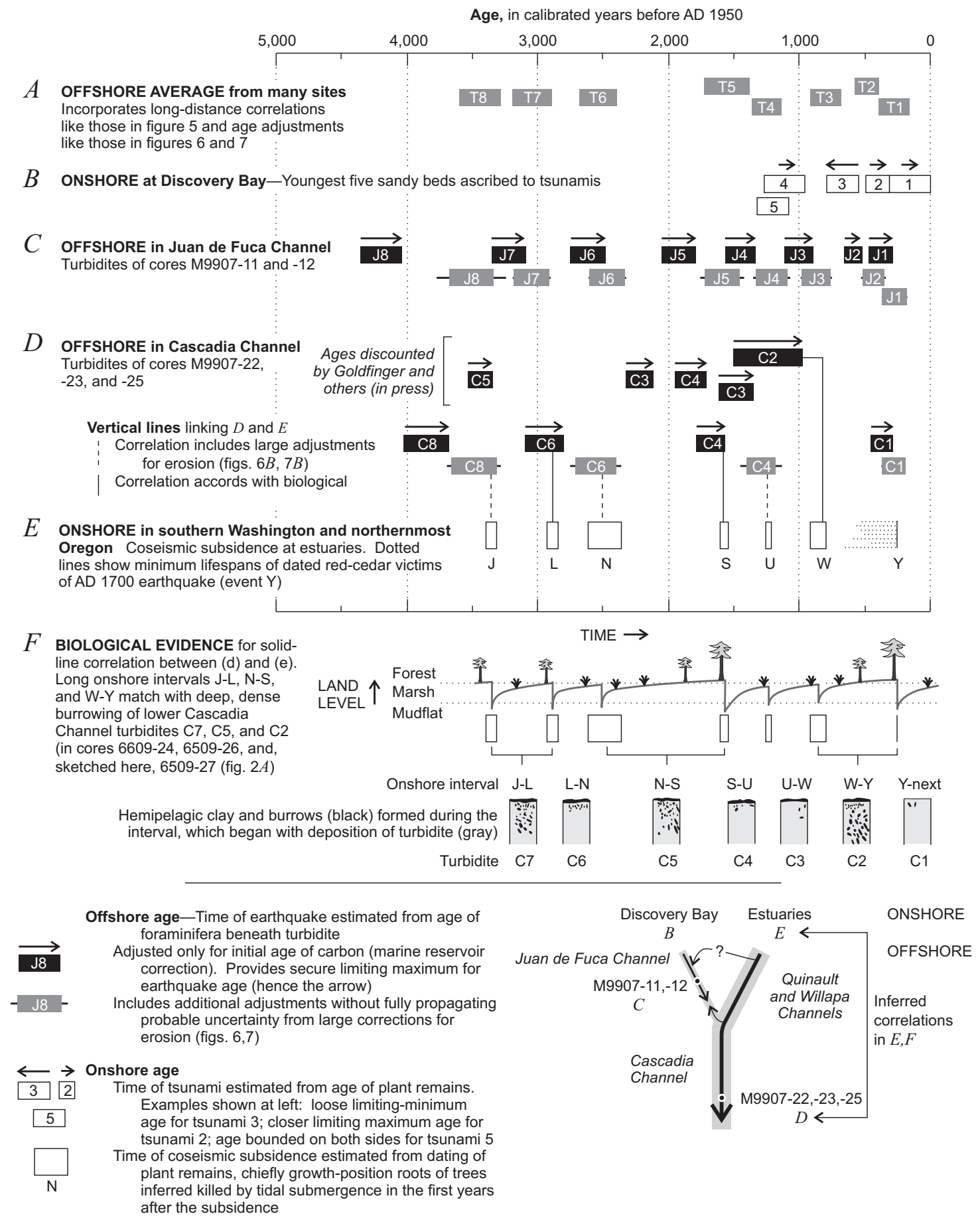

Figure 8. Comparisons of earthquake ages inferred from offshore and onshore evidence. $A$, Combined deep-sea turbidite chronology of Goldfinger and others (in press). B, Tsunami deposits along Strait of Juan de Fuca (Williams and others, 2005). C,D, Turbidites of Juan de Fuca Channel and lower Cascadia Channel (Goldfinger and others, in press, appendix 1, "RC data" worksheet). Symbols further explained in our figure 7C. E, Estuarine evidence in southern Washington and northernmost California (2004; Hagstrum and others, 2004), with tree-ring data of Yamaguchi and others (1997) and new radiocarbon ages for W. The new ages, described in the text, were converted to calibrated years using an error multiplier of 1, the software Calib 6.1.0, and the IntCal 09 data of Reimer and others (2009). F, Comparison of $E$ with burrows in turbidites of lower Cascadia Channel, traced from the sketch of core 6509-27 in Griggs and others (1969). 